Political Participation of Refugees: Bridging the Gaps

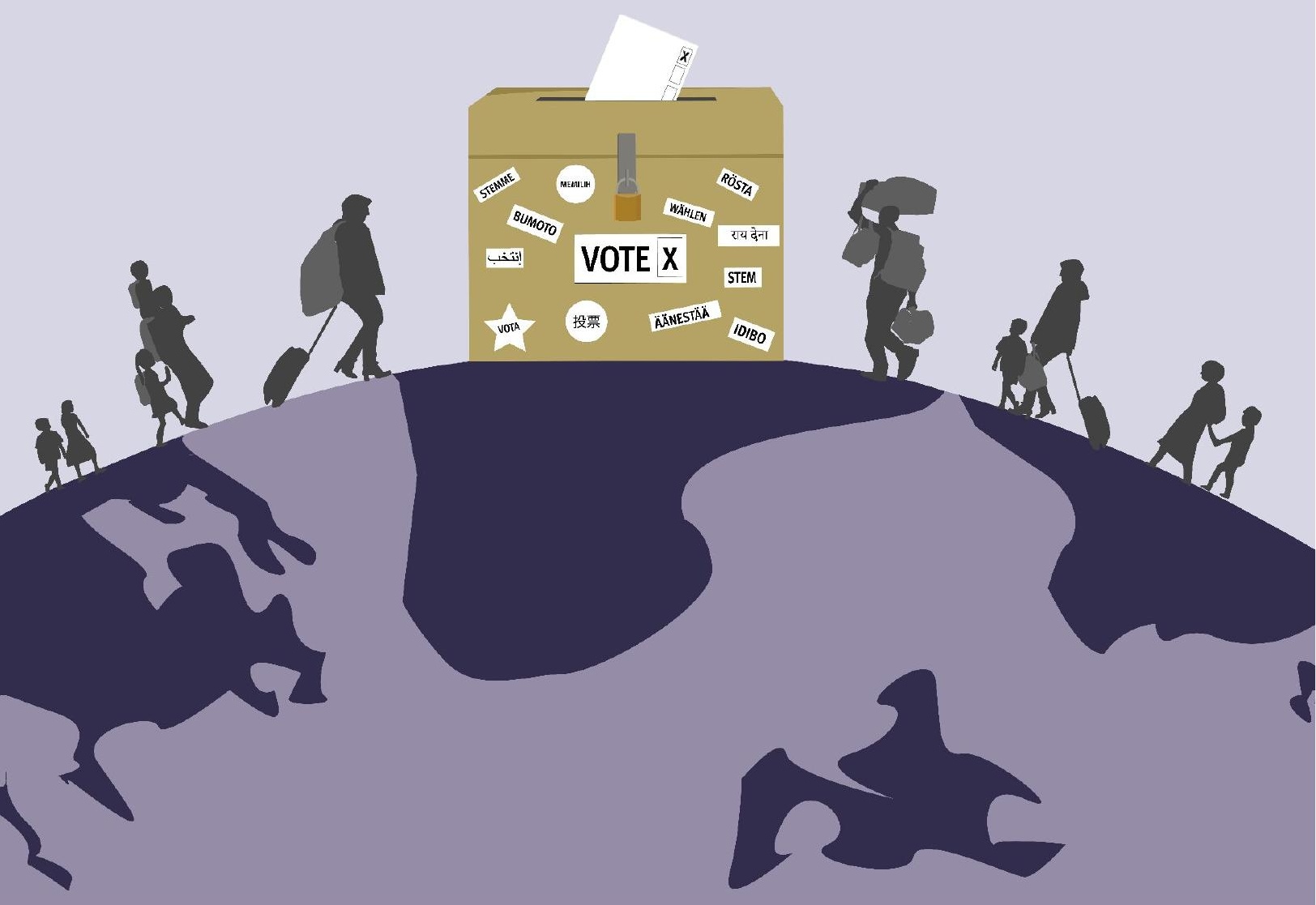




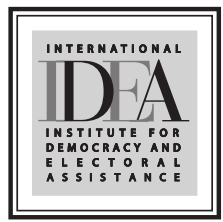

\section{Political Participation of Refugees: Bridging the Gaps}

Lead authors: Armend Bekaj and Lina Antara

Contributors: Tarig Adan, Jean-Thomas Arrighi de Casanova, Zeina El-Helou, Ezra Mannix, Mukondeleli Mpeiwa, Caleb Otieno Opon, Nora Jasmin Ragab, Shoaib Sharifi and Tigranna Zakaryan

As part of the Refugees, Asylum Seekers

Robert Bosch Stiftung and Democracy project, this report was made possible by funding from the Robert Bosch Stiftung. 
(C) 2018 International Institute for Democracy and Electoral Assistance

International IDEA publications are independent of specific national or political interests. Views expressed in this publication do not necessarily represent the views of International IDEA, its Board or its Council members.

\section{(9)(1)(9)}

The electronic version of this publication is available under a Creative Commons AttributeNonCommercialShareAlike 3.0 (CC BY-NC-SA 3.0) licence. You are free to copy, distribute and transmit the publication as well as to remix and adapt it, provided it is only for non-commercial purposes, that you appropriately attribute the publication, and that you distribute it under an identical licence. For more information visit the Creative Commons website: 〈http://creativecommons.org/licenses/by-nc-sa/3.0/〉.

International IDEA

Strömsborg

SE-103 34 Stockholm

Sweden

Telephone: +4686983700

Email: info@idea.int

Website: 〈http://www.idea.int〉

Cover illustration: Joshua Sowah

Interior illustrations: KSB Design

Design and layout: International IDEA

ISBN: 978-91-7671-148-4

Created with Booktype: 〈https://www.booktype.pro〉 


\section{Contents}

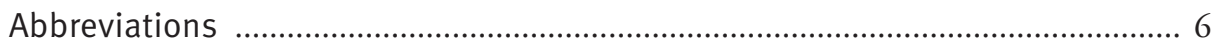

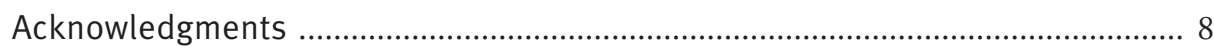

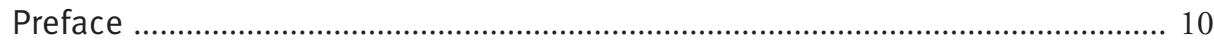

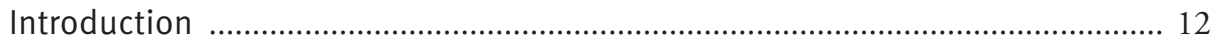

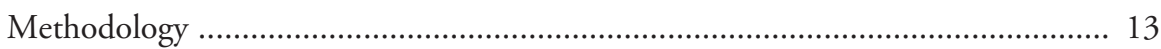

Overview of case studies .................................................................................. 17

Part I. Political Participation of Refugees in their Host Countries ....................... 23

1. Formal political participation of refugees in their host countries ................... 25

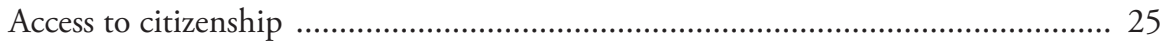

Access to electoral rights and political parties ....................................................... 35

2. Non-formal political participation of refugees in their host countries ........... 49

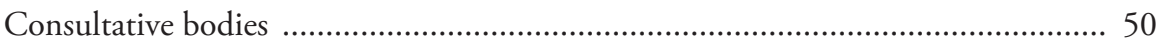

Participation in civil society organizations ........................................................ 54

Protests and grassroots initiatives ........................................................................ 64

Part II. Political Participation of Refugees in their Countries of Origin ............... 70

3. Formal political participation of refugees in their countries of origin ............ 72 
Electoral rights and out-of-country voting

4. Non-formal political participation of refugees in their countries of origin .... 81

Civil society and diaspora organizations ........................................................ 82

Protests and other forms of transnational political activism ............................... 88

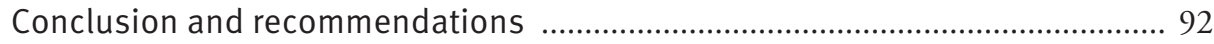

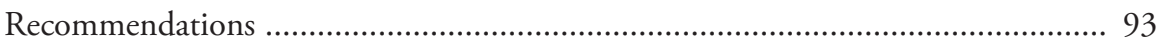

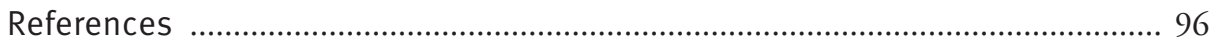

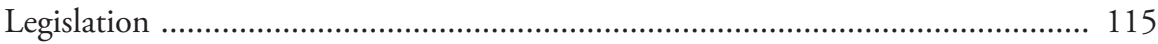

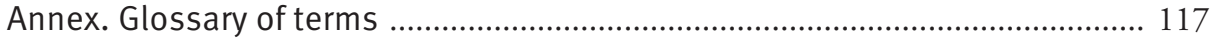

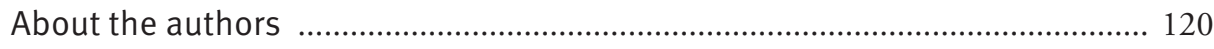

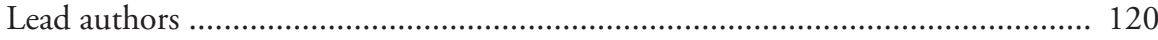

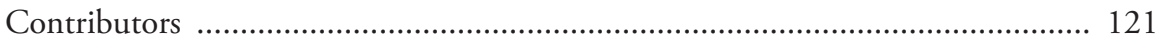

About the Refugees, Asylum Seekers and Democracy project ........................ 124

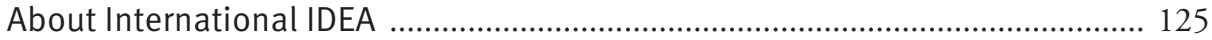




\section{Abbreviations}

ANC African National Congress

BAGFA Federal Association of Volunteer Agencies (Germany)

CCSA Congolese Community in South Africa

CCWC Congolese Community in the Western Cape

CDU Christian Democratic Union of Germany

CoRMSA Consortium for Refugees and Migrants in South Africa

CSO Civil society organization

CSU Christian Social Union (Germany)

HDP People's Democracy Party (Turkey)

DRC Democratic Republic of the Congo

IOM International Organization for Migration

NCSROF National Coalition of Syrian Revolution and Opposition Forces 
NGO Non-governmental organization

OCV Out-of-country voting

OPM Office of the Prime Minister (Uganda)

RQA Return of Qualified Afghans programme

SAP Social Democratic Party (Sweden)

SPD Social Democratic Party of Germany

SSNP Syrian Social Nationalist Party (Lebanon)

UCC Ugandan Constitutional Court

UNHCR United Nations High Commissioner for Refugees

UCICA Citizenship and Immigration Control Act (Uganda) 


\section{Acknowledgments}

As part of the Refugees, Asylum Seekers and Democracy project, this report was made possible by funding from the Robert Bosch Stiftung. We are particularly indebted to Ana Bojadjievska for her remarkable dedication and support throughout the implementation of the project and for thoroughly peer reviewing this report. Additional thanks go to the Robert Bosch Stiftung's staff members Claudia Fisches and Markus Lux for the excellent collaboration.

We wish to express our sincere gratitude and appreciation to Jean-Thomas Arrighi de Casanova for producing a thought-provoking, insightful and engaging review of the relevant academic literature which has been instrumental in bringing this report to life. We also gratefully acknowledge the valuable contributions of the eight case study authors: Tarig Adan (The Case of Syrian and Somali Refugees in Sweden), Zeina El-Helou (The Case of Syrian Refugees in Lebanon), Ezra Mannix (The Case of Syrian Refugees in Turkey), Mukondeleli Mpeiwa (The Case of Congolese Refugees in South Africa), Caleb Otieno Opon (The Case of Somali and South Sudanese Refugees in Kenya), Nora Jasmin Ragab (The Case of Afghan and Syrian Refugees in Germany), Shoaib Sharifi (The Case of Afghan Refugees in the United Kingdom) and Tigranna Zakaryan (The Case of South Sudanese and Congolese Refugees in Uganda).

Special acknowledgment goes to Professor Michael Collyer and Dr Reuven Ziegler for peer reviewing the report and providing valuable feedback during its development.

We also thank the participants in the 'Refugees, Asylum Seekers and Democracy' round table held on 5-6 September 2017 in Stockholm: Micheline Minani Muzaneza Bagona, Luis Martinez Betanzos, Myriam Chilvers, Adam Elsod, Malin Frankenhaeuser, Dina Mansour-Ille, Sonja Meyer, Awil Mohamoud, Erik Nilsson, Victor Nyamori, Eva Østergaard-Nielsen, Scott Pohl 
and Ana Maria Vargas. Their fresh ideas and insights informed the development of this report.

We are especially grateful to our International IDEA colleagues Nathalie Ebead, Rosinah Ismail-Clarke, Helena Schwertheim and Thomas Smith for their support and assistance during various stages of the content development of this report. We would also like to thank Lisa Hagman, Frank McLoughlin and David Prater who have generously given their time, ideas and support during the conceptualization, editing and production process.

Finally, we would like to extend our thanks to Andrew Mash for his professional input in providing timely editing of this report. 


\section{Preface}

A great variety of studies and reports examine the humanitarian and security aspects of the lives of refugees and asylum seekers. It is indeed very important to bring these issues to the public debate, particularly considering the ongoing bloody conflicts that result in millions of people becoming displaced or seeking shelter in other countries. However, the political inclusion of refugees and asylum seekers in decision-making, or the normative framework that enables or inhibits such participation, is largely left to the individual discretion of host or origin countries.

There are a number of differing norms and practices that enable or inhibit asylum seekers and refugees from taking part in political life. Quite often, their opportunities for participation are rather limited, which in turn perpetuates their marginalized status in society. For this reason, there is a need for a wider debate among policymakers, academia, and international and regional organizations that explores the engagement of asylum seekers and refugees in political processes as a way to ensure greater social inclusion and strengthen democratic norms and practices.

This is why International IDEA has deemed it important to conduct a study that examines this issue, which impacts the democratic fabric of any country, regardless of whether it is conflict-ridden or the recipient of refugees and asylum seekers. The Institute understands and promotes the notion of democracy as a political system based on popular control and political equality, and as an ideal that seeks to empower ordinary people by guaranteeing equality and basic freedoms, as well as peaceful dialogue. The topic of this report, therefore, comes as a natural product that derives from International IDEA's understanding of democracy. 
This report focuses on eight host countries-Germany, Kenya, Lebanon, South Africa, Sweden, Turkey, Uganda and the United Kingdom-and five countries of origin: Afghanistan, the Democratic Republic of the Congo, Somalia, South Sudan and Syria. It offers comparative analysis on different mechanisms for formal and non-formal political participation.

Among the formal mechanisms of participation, the report looks at issues of access to citizenship, electoral rights and membership of, or other forms of association with, political parties. Non-formal mechanisms of political participation include refugees' participation in consultative bodies, civil society organizations, protests and grassroots initiatives, and other means of transnational political activism. Further strengthening the report's credibility, it includes firsthand data resulting from interviews and surveys with asylum seekers and refugees conducted in the field.

The report offers a number of concrete and actionable recommendations for governments, political parties, civil society and international and regional organizations, which are directed towards making political participation more practical, and which in turn helps make democracy more inclusive.

The report also comes out at a time when the debate around global migration is gathering momentum. In the last couple of years International IDEA has been following up closely on the measures taken ahead of the first intergovernmental negotiations on the Global Compact for Safe, Orderly and Regular Migration (Global Compact on Migration), and on the Global Compact on Refugees, prepared under the auspices of the United Nations and the UN High Commissioner for Refugees, respectively. The Institute was pleased to witness the release of the Zero Draft of the Global Compact on Migration in February this year. This cooperative framework between UN member states, among others, acknowledges the importance of political participation and inclusion of migrants for ensuring greater social cohesion and inclusive political reform.

By echoing the clarion call of the Global Compact on Migration, the theme of this report also acknowledges the issue of political participation of refugees in their host countries and countries of origin. International IDEA is committed to promoting good governance and an inclusive system of democracy that promotes diversity and offers opportunities for participation. This report will contribute to the public debate on this topic by highlighting some of the shortfalls for refugees' political participation, but also by suggesting ways to work towards a more inclusive system of governance.

Yves Leterme

Secretary-General

International IDEA 


\section{Introduction}

The global refugee population reached an estimated 22.5 million in mid-2017, compared to 10.4 million in 2011. The world is witnessing an exceptional increase in the number of refugees and people in refugee-like situations. In 2017 more than half of the global refugee population came from just three countries: Syria, Afghanistan and South Sudan. Although 84 per cent of refugees worldwide are hosted by countries in the Global South-with Turkey hosting the greatest number, followed by Lebanon, Uganda and Kenya-European countries such as Germany and Sweden are also experiencing an unprecedented increase in refugee flows (UNHCR 2017a).

Asylum seekers and refugees are among the most marginalized groups in society. They are often subjected to persecution, violent conflict and other lifethreatening situations. The path from their home countries to a better and safer environment is also hindered by numerous dangers and insecurities. They embark on often dangerous journeys with the aim of finally reaching a host country that will offer them safety, stability and opportunities to rebuild their lives. Once in their host country, it is no coincidence that the main preoccupations are related to settling into the new environment and grappling with the daily socio-economic challenges of survival and integration. They will usually maintain contacts with their country of origin, which might involve economic remittances, philanthropy and human capital (Brinkerhoff 2009). However, compared to more pressing humanitarian and livelihood-related concerns, political engagement might seem to be an extravagant commodity that can hardly be afforded. Similarly, the public debate surrounding refugees usually focuses on the humanitarian, social, economic and security aspects of forced migration. Issues related to the civic and political participation of refugees are largely overlooked. Refugees are often seen as passive recipients of humanitarian aid or collective subjects in respect of which 
measures must be taken, rather than as active political agents. Nonetheless, refugees have the potential to be dual political actors, since they often maintain transnational links with their homelands while at the same time becoming part of the host country's society.

This report explores the challenges and opportunities related to the political participation of refugees in their host countries and countries of origin. What means can be utilized to enhance formal and non-formal participation by refugees in the political life of their host countries and countries of origin? What legal and institutional mechanisms provide an enabling environment that fosters such participation? What legal and practical factors might hinder their political participation? The report seeks to shed light on these questions through a comparative analysis of eight case studies carried out in Germany, Kenya, Lebanon, South Africa, Sweden, Turkey, Uganda and the United Kingdom, focused on refugees from Afghanistan, the Democratic Republic of the Congo, Somalia, South Sudan and Syria.

For the sake of clarity, this report discusses refugees' political participation in their host countries separately from their political participation in their countries of origin. Both parts, however, examine the legal, normative and practical aspects of formal and non-formal political participation by refugees. The formal mechanisms for refugees' political participation in their host countries are analysed in Part I, with an emphasis on specific issues related to access to citizenship, electoral rights and participation in political parties. Non-formal mechanisms, such as consultative bodies, civil society organizations (CSOs), protests and grassroots initiatives, are also discussed. Part II addresses issues related to political participation by refugees in their countries of origin. In particular, electoral rights and out-of-country voting (OCV) are discussed as mechanisms for formal political participation, as well as non-formal mechanisms for political engagement by refugee diasporas, such as participation in civil society and diaspora organizations, protests and other forms of transnational political activism. The report presents a set of policy recommendations on the political inclusion of refugees addressed to relevant institutions in host countries and countries of origin.

\section{Methodology}

As a political system based on popular control and political equality, democracy is an ideal that seeks to guarantee equality and basic freedoms, empower ordinary people, resolve disagreements through peaceful dialogue, respect differences and bring about political and social renewal without economic and social disruption (International IDEA 2017: xiv). Based on this concept, the analysis of the different mechanisms for political participation used by the refugees in this report is extended beyond participation in formal political institutions and processes. 
Among the formal mechanisms for political participation, the report explores issues of access to citizenship in host countries, electoral rights in both host countries and countries of origin, as well as membership of or providing other forms of support to political parties. In addition, acknowledging that political life is not only confined to electoral processes, the report examines non-formal mechanisms of political participation, such as refugees' participation in consultative bodies, CSOs, protests and grassroots initiatives, as well as other means of transnational political activism. Given that some of the countries in this report either are not signatories to the 1951 Convention Relating to the Status of Refugees (1951 Refugee Convention) or maintain a geographical restriction on its application, this report considers refugees, persons in refugee-like situations and persons who have been granted any form of international protection.

The report's methodology is based on a combination of primary and secondary sources. It uses primary qualitative data collected from eight case studies and draws on relevant academic and policy literature on the normative aspects of the participation of refugees in the political life of their host countries and countries of origin. In addition, it examines the legal basis for their political participation and provides a comparative overview of selected countries' practices with regard to formal and non-formal participation by refugees. Primary sources examined include international treaties, constitutions and domestic laws that regulate residency, citizenship, voting rights, participation in political parties, running for elected office and forming CSOs, as well as other legal provisions that directly affect refugees' political participation.

The eight host countries where field research was conducted with refugees and asylum seekers, and the five countries of origin, are listed in Table 1.

Table 1. Case study countries

\begin{tabular}{|l|l|}
\hline Host country & Countries of origin \\
\hline Germany & Afghanistan, Syria \\
\hline Kenya & Somalia, South Sudan \\
\hline Lebanon & Syria \\
\hline South Africa & Democratic Republic of the Congo \\
\hline Sweden & Somalia, Syria \\
\hline Turkey & Syria \\
\hline Uganda & Democratic Republic of the Congo, South Sudan \\
\hline United Kingdom & Afghanistan \\
\hline
\end{tabular}


The countries of origin were selected on the basis of a statistical analysis which found that they were among the top 10 refugee-producing countries in 2015 and 2016 (UNHCR 2016, 2017a). The host countries were selected for case studies based on:

- the absolute number of refugees hosted in these countries at the end of 2015;

- the number of refugees per 1,000 inhabitants at the end of 2015;

- the number of asylum applications submitted in 2015;

- the number of asylum applicants per 1 million inhabitants in 2015;

- the feasibility of conducting reliable field research in these countries, including the availability of literature on the political participation of refugees, levels of safety and security, and the availability of competent field researchers;

- a balance between countries of the Global South and those of the Global North; and

- a preliminary assessment of whether research in the selected host countries was likely to provide insights that would serve to showcase different mechanisms for refugees' political participation.

On this last point, particular aspects that were taken into account included (a) the extent to which these countries have legal pathways to long-term residency and citizenship for refugees; (b) the extent to which naturalized residents and/or resident non-citizens are granted the right to vote in national, regional or local elections; and (c) the extent to which refugees and/or naturalized citizens with a refugee background from the selected countries of origin have a significant presence in the selected host countries.

The field research in the selected countries was carried out in the period MayAugust 2017 through interviews, focus group discussions and written surveys of refugees from the targeted countries of origin, on the basis of a standard questionnaire that combined fixed and open-ended questions (International IDEA n.d.). This approach allowed the research to retain its focus while at the same time enabling respondents to provide detailed answers and capture the diversity of their experiences. The research locations in each host country included at least the capital city and a second city or refugee camp with a large refugee population from the targeted countries of origin.

Acknowledging the heterogeneity and diverse experiences and backgrounds of refugees, each case study was based on a diverse sample of respondents. Particular consideration was given to achieving a balance of genders, ethnicities, religions, 
ages and political groups, to the extent possible. In addition, interviews and consultations were conducted with key informants such as representatives of nongovernmental organizations (NGOs) and CSOs, and with national or local authorities working on refugee-related issues in the selected host countries. For ethical and security reasons, the identities of the respondents are withheld throughout this report and in the case studies.

In total, 23 key informants and 615 refugee respondents participated in this research, of whom 407 were men and 208 women (see Table 2). Although the qualitative analysis does not claim to be statistically representative of the host countries' refugee population as a whole, it does offer unique insights into the various complexities of refugees' experiences, as well as the opportunities and challenges they face with formal and non-formal political participation in their host countries and countries of origin. It is well beyond the scope of this report to discuss the humanitarian and security dimensions of forced migration. Nor does it aim to assess the effectiveness of refugee integration policies in the targeted countries from a socio-economic perspective. Instead, it seeks to provide an indepth understanding of the specific issues related to refugees' political participation in both their host countries and their countries of origin, which can inform the ongoing debate on the political participation of refugees and serve as a basis for further research and future policy reforms.

\section{Table 2. Summary of respondents per country}

\begin{tabular}{|c|c|c|c|c|}
\hline \multirow[t]{2}{*}{ Host country } & \multicolumn{2}{|c|}{ Refugee respondents } & \multirow{2}{*}{$\begin{array}{l}\text { Key } \\
\text { informants }\end{array}$} & \multirow[t]{2}{*}{ TOTAL } \\
\hline & Male & Female & & \\
\hline Germany & 14 & 4 & 3 & 21 \\
\hline Kenya & 56 & 54 & 5 & 115 \\
\hline Lebanon & 4 & 2 & 3 & 9 \\
\hline South Africa & 59 & 16 & 4 & 79 \\
\hline Sweden & 40 & 25 & 3 & 68 \\
\hline Turkey & 52 & 9 & 0 & 61 \\
\hline Uganda & 102 & 78 & 5 & 185 \\
\hline United Kingdom & 80 & 20 & 0 & 100 \\
\hline TOTAL & 407 & 208 & 23 & 638 \\
\hline
\end{tabular}




\section{Overview of case studies}

This section provides a brief overview of the eight case studies that inform the analysis in Parts I and II.

\section{The Case of Afghan and Syrian Refugees in Germany}

Afghan and Syrian refugees and asylum seekers are the two largest groups of refugees and asylum seekers in Germany. Regarding the host country, the case study found that non-formal political participation provides refugees with a platform to engage in German political life. This is particularly significant as the German legal framework excludes non-European resident non-citizens, and therefore refugees and asylum seekers, from participating in formal political institutions and processes. Hence, migrant representative bodies, as well as migrant and refugee organizations, provide crucial tools for political participation and serve to empower refugee and asylum seeker communities at the local and regional levels. At the individual level, the case study found that refugees in Germany face many barriers to becoming active participants in their host country's political life. In particular, their insecure legal status and the negative stereotyping of the refugee discourse have proved major hurdles to refugees' political participation in Germany.

The study also found that the protracted nature of the Afghan and Syrian conflicts has limited any opportunities for refugees and asylum seekers to participate in formal political processes in their countries of origin. In the Afghan context, despite the existence of legal provisions on political participation by the refugee diaspora through OCV, as of March 2018 no arrangements had been made for the organization of OCV during the Afghan parliamentary elections scheduled for 2018. In the Syrian context, despite the existence of a legal framework for OCV, the absence of a functioning democratic system seems to have intensified respondents' resistance to formal political systems. Nonetheless, in lieu of this, the interview findings show that civil society movements are fast emerging among Syrian and Afghan communities, and these have become transnational in nature as activists continue the struggle for democracy from abroad. However, although these can be crucial forces in the peacebuilding and democracy-building processes of both countries, they are unlikely to be able to resolve complex and protracted crises on their own (Ragab 2018).

\section{The Case of Somali and South Sudanese Refugees in Kenya}

Somali and South Sudanese nationals represent the two largest groups of refugees and asylum seekers in Kenya. This case study found that Somali and South Sudanese respondents were more concerned with meeting their basic needs than engaging in host country politics. On closer inspection, it also found that most 
respondents were worried that involving themselves in Kenyan politics would have a negative effect on their current legal status. Although this case study is not statistically representative of all refugees and asylum seekers in Kenya, it did manage to document the sentiments of refugees and portray their genuine concerns over issues of discrimination, harassment and the restrictions on their freedom of movement within Kenya. All these factors, coupled with the barriers associated with Kenya's encampment policy and stringent naturalization policy, significantly restrict the ability of refugees to directly engage in formal and nonformal political activities in Kenya.

In similar ways, given the lack of one-person-one-vote elections and the absence of a legal framework for OCV, both Somali and South Sudanese refugees have very limited opportunities to participate in formal political processes and institutions in their countries of origin. However, the case study argues that Somali and South Sudanese refugees have the potential to play an important role in the politics of their countries of origin through forms of non-formal political participation. Capacity-building and civic education initiatives can diffuse democratic values to their countries of origin and increase awareness of civil and political rights (Opon 2018).

\section{The Case of Syrian Refugees in Lebanon}

Lebanon is host to the highest number of Syrian refugees per capita in the world (European Commission 2017). However, Lebanon has been reluctant to allow the long-term settlement of refugees in its territory, which means that opportunities for Syrians to naturalize and gain access to voting rights in Lebanon have been very limited. Furthermore, the case study found strong opinions against treating Syrians as 'fully fledged refugees', in terms of allowing them to enjoy civil and political rights, given that Lebanon is not a signatory of the 1951 Refugee Convention. Many of the interviewees expressed reluctance to participate in any formal Lebanese political processes. Although there are many legal obstacles to the establishment and operation of Syrian-led CSOs in Lebanon, non-formal political participation is tolerated much more when it comes to addressing 'Syrian issues', such as activities aimed at promoting peacebuilding and social cohesion.

With regard to country-of-origin political participation, Lebanon was one of the few countries where OCV was possible for Syrians in the 2014 presidential elections. However, restrictive policies and regulations have been put in place by the Lebanese authorities since the 2014 Syrian elections as a direct response to the high turnout among Syrians voting for President Assad. In addition, the case study found that political advocacy initiatives and the role of Lebanon-based Syrian refugees in democracy building in Syria are limited. The lack of basic means for survival and the precarious legal status of many Syrian refugees in Lebanon often had negative consequences for refugees' willingness to openly 
engage in transnational political activities aimed at making an impact on democracy building in Syria. Nonetheless, the case study also found some room for Syrian refugees to engage in political activities in their country of origin from within Lebanon, through capacity-building and advocacy initiatives (El-Helou 2018).

\section{The Case of Congolese Refugees in South Africa}

South Africa's policy framework on the protection of refugees aims to promote their access to basic and civil rights. Although the South African Constitution guarantees the same civil rights to everyone, electoral rights are solely reserved for South African citizens. However, this does not mean that non-citizens cannot get involved. The Constitution gives everyone the right to join a political party. While this may not, at least at first, offer refugees the opportunity to stand for office, political party membership can be a platform from which to influence the political discourse and policy positions. One underlying concern that most of the interviewees raised when asked about their civic and political participation in South Africa was that engaging in political activity might result in a revocation of their refugee status or a negative decision on the extension of their residence permits. Nonetheless, this has not stopped many Congolese refugees from participating in non-formal processes from the grassroots level up. Moreover, the refugees' constitutionally guaranteed right to protest means that they are able to convene at key strategic points to express their political concerns and raise awareness of and public support for certain contentious issues.

The lack of legal provisions for OCV has made it difficult for Congolese refugees to formally participate in the politics of their country of origin. Given the travel limitations, particularly in relation to return to the Democratic Republic of the Congo (DRC), refugees are unable to participate in elections without placing their legal status as refugees in South Africa at risk. For some, it remains easier to stay involved through the local branches of Congolese political parties that have been established in South Africa. In addition to the more visible forms of protest, some refugee groups are engaging with the media and using diplomacy as a tool to engage with stakeholders they believe might be able to influence outcomes in the DRC. To a large extent, most of the refugee leaders interviewed for this study were looking forward to their return to a post-conflict DRC, where they expected to play a leadership role in the reconstruction process (Mpeiwa 2018).

\section{The Case of Syrian and Somali Refugees in Sweden}

Syrian and Somali refugees and asylum seekers represent the two largest groups of refugees and asylum seekers in Sweden. Both groups are able to engage in formal and non-formal processes of political life in Sweden, even before they acquire Swedish citizenship. They have the right to vote and stand as candidates in 
regional and municipal elections, the right to join political parties and participate in electoral campaigns, opportunities to organize or participate in protests and make their voices heard, and the right to form associations and CSOs. Nonetheless, despite these favourable legal frameworks and policies, visible and invisible barriers make it difficult for refugees to participate in Swedish politics on equal terms with the rest of the population. One factor is the lack of knowledge or awareness of the importance of democracy and political participation and its impact on the refugee population, and therefore of understanding the need to vote. This lack of knowledge, combined with a lack of information sharing, contributes to a limited interest in being part of the decision-making processes in the host country. Some respondents highlighted the fact that they felt isolated and marginalized from mainstream society, and that this was one factor that discouraged them from participating in Swedish political life. Another key finding was that, due to persistent cultural, religious and structural barriers, women from both respondent groups faced particular challenges and were widely excluded from political life in both their host country and their countries of origin. As a result, their political participation was limited, especially in the years directly following their arrival in Sweden.

The case study found that diaspora communities can make a significant contribution to building bridges between states and promoting democracy in refugees' and asylum seekers' countries of origin. The case of the Somali diaspora is a good example, as it illustrates how experiences of civic and political life in Sweden can be used to transfer knowledge and skills to a country of origin. However, ethnic, religious and political fragmentation, as well as authoritarian legacies, can often hinder any effective engagement by the diaspora in the political life of its country of origin. That said, if the political and security situations permit, both the Syrian and the Somali diaspora possess skills and expertise that would allow them to engage constructively in the political life of their countries of origin (Adan 2018).

\section{The Case of Syrian Refugees in Turkey}

As of July 2017, Turkey had the highest number of refugees in the world (UNHCR 2017b). Given the ongoing conflict in Syria and Turkey's commitment to its locally developed asylum system, it appears unlikely that the asylum status of Syrian refugees in the country will change in the near future. It is important to stress that none of the participants in this case study had the right to vote in Turkey, as they did not meet the requirements for obtaining Turkish citizenship. However, most of the respondents identified that the most impactful way to engage with the government was through non-formal processes of political participation. Many of the respondents believed that this gave them a stronger voice on policies that might potentially affect them. 
Most of the respondents remained inactive in the formal processes of political participation in Syria. The overwhelming majority of respondents agreed that they would participate in future rounds of OCV only if they were given assurances that the process would be free and fair. In terms of non-formal political participation, the case study highlights the sporadic and limited attempts that have been made. As Syrians stay longer in Turkey, some will eventually qualify for naturalization. Most will continue to live under temporary protection, however, meaning that most will be unable to formally participate in either hostcountry or country-of-origin politics (Mannix 2018).

\section{The Case of South Sudanese and Congolese Refugees in Uganda}

South Sudanese and Congolese refugees and asylum seekers comprise the two largest refugee communities in Uganda. The legal framework in Uganda prohibits refugees from engaging in formal political activities, such as participation in national and local elections or joining political parties. Opportunities for the naturalization of long-term refugees are also highly restricted due to ambiguities in the legal framework. However, despite the lack of access to formal political participation in Uganda, Refugee Welfare Committees and refugee-led CSOs do play a limited but active role as consultative bodies on behalf of the wider refugee community.

The case study found no avenues for formal political participation in their countries of origin, given the current political and security concerns in both South Sudan and the DRC. Moreover, there is no legal framework in place for OCV to facilitate refugees' participation in future elections. Nonetheless, a common theme in the interviews was that refugees felt that they were becoming more unified through their shared experiences of exile. This gave them the will to promote democracy in their countries of origin (Zakaryan 2018).

\section{The Case of Afghan Refugees in the United Kingdom}

Afghan refugees in the UK are deprived of the right to vote in both their host country and their country of origin. In the former case, this is for a period of at least seven years, until they become eligible to apply for British citizenship. Nonetheless, they have found alternative ways to make their voices heard and participate in the civic and political life of the UK and Afghanistan. The study found a growing tendency among Afghan refugees and asylum seekers to get involved in the British political arena. Almost all the interviewees saw an understanding of their host country's political system as an important element of integration into British society. Among the positive elements was the openness of the membership criteria of British political parties and CSOs, which makes it possible for refugees to pursue various forms of participation in civic and political life short of the right to vote. For Afghan refugees, informal civil society and political gatherings in the form of cultural and literary associations, refugee rights 
advocacy groups, charities and ethnic associations are common spaces where naturalized and non-naturalized refugees, as well as asylum seekers, can participate in a single platform and advocate for a common cause.

The case study found that Afghan-born, UK-based refugees and asylum seekers have a great interest in the politics of their country of origin. However, due to the lack of implementation of OCV mechanisms, they cannot formally participate in Afghan politics unless they travel to Afghanistan, which is not an option for those with refugee status as this would lead to revocation of that status. Against this background, issues related to the political life of Afghanistan are usually addressed through informal gatherings of and initiatives by Afghan refugees in the UK. There are also plenty of small foundations fundraising for development projects back home, such as schools, clinics and help for individuals to kick-start businesses. The use of social media and online platforms, especially by the younger generation of Afghan refugees, has also played an important role in keeping up to date with political developments in their country of origin and engaging in political debates in both the UK and Afghanistan (Sharifi 2018). 


\section{Part I. Political Participation of Refugees in their Host Countries}

How do refugees experience political engagement in their host countries? What international standards and practices are relevant to this issue? Is there an overarching legal or normative framework? If so, do some countries take a more individual approach and not necessarily subscribe to such a framework? What are the prerequisites for refugees to be able to engage in the political processes of their host countries? Lastly, what are the key challenges and best practices related to the formal and non-formal political participation of refugees in their host countries? There are no straightforward answers to these questions as regulation of the various aspects of political participation by refugees is usually left to the discretion and sovereignty of individual host countries. In addition, the answers to these questions often depend on the country of origin of the refugee concerned, as well as on whether participation is formal, which would entail a domestic legal framework granting access to naturalization and voting rights, or non-formal, in which case a favourable legal and institutional framework is not always required.

Consider the fictional case of a Colombian who has fled protracted violence in his native region and for the past five years has been legally residing in Spain. $\mathrm{He}$ was initially granted a one-year temporary protection visa that was renewed the following year. After two years of residence, as a Colombian he could apply for Spanish citizenship while retaining his original citizenship, a dual privilege reserved to applicants from Andorra, Equatorial Guinea and Latin America. As a newly naturalized Spanish citizen, he could have cast a ballot in the national elections held in 2016 and in the regional elections held in 2015. In addition, his Colombian passport gave him the opportunity to directly elect his own deputy to 
the Colombian National Assembly in the Colombian legislative elections of 2014. His situation contrasts sharply with that of his next-door neighbour, a citizen of the Democratic Republic of the Congo who, after several years spent in a legal limbo as an asylum seeker, was finally granted refugee status, which eventually led to a permanent residence permit. However, the prospects for obtaining the right to vote in her host country or exercising the right to vote in elections held in her country of origin look grim. The DRC's electoral legislation does not allow for OCV; and the path to naturalization in Spain for applicants who do not fall into one of the special categories mentioned above requires applicants to prove at least 10 years of residence and to renounce the citizenship of their country of origin.

These two protagonists inhabit a transnational space that spans state boundaries and results from their recognized refugee status (Vink, De Groot and Luk 2015). While their claim to a political voice in the political communities of both their host country and their countries of origin should be equally valid, their formal political rights differ markedly. The former enjoys the benefits of a genuinely transnational and active citizenship, allowing him to have his interests represented in home- and host-country politics, whereas the latter is essentially deprived of any formal means of political participation. The above juxtaposition of alternative legal statuses underlines how the means for formal political participation depend to a large degree on the citizenship of the refugee in question and the electoral laws in the country of origin, as well as the legal framework regulating naturalization and electoral rights in the host country.

Away from participation in formal institutions and processes, both Colombian and DRC nationals are able to make their voices heard in both their host countries and their countries of origin through non-formal means of political participation. They may find themselves, for instance, advocating together for a political party in their host country, participating in peaceful protests against certain policies of their host countries or being co-founders of a social mediabased platform for the exchange of political ideas. 


\section{Formal political participation of refugees in their host countries}

The obvious and most direct way for refugees to participate formally in the political life of their host countries is through voting. While approximately 45 countries worldwide have legislation granting the right to vote, mainly in local elections, to all or specific categories of resident aliens (Pedroza 2014; Earnest 2015), in the vast majority of countries the local or national franchise is still the prerogative of citizens. As a result, refugees must first naturalize before they are able to cast a ballot in their host country.

Article 25(b) of the International Covenant on Civil and Political Rights recognizes the right of every citizen to vote and be elected in genuine periodic elections by universal and equal suffrage, but this right applies only to citizens, and the criteria for the acquisition of citizenship through naturalization are left to the discretion of signatory states. However, the United Nations Independent Expert on minority issues has called on states to 'consider allowing non-citizens belonging to minorities to vote, stand as candidates in local elections and be members of the governing boards of self-governing bodies, while making sure that access to citizenship is regulated in a non-discriminatory manner' (UN Human Rights Council 2010).

\section{Access to citizenship}

Article 34 of the 1951 Refugee Convention requires that the 'Contracting States shall as far as possible facilitate the assimilation and naturalization of refugees. They shall in particular make every effort to expedite naturalization proceedings 
and to reduce as far as possible the charges and costs of such proceedings'. In the same vein, the Zero Draft of the Global Compact on Refugees (UNHCR 2018), which was developed as a follow-up to the 2016 New York Declaration for Refugees and Migrants (United Nations 2016), refers to the granting of permanent residence or naturalization for refugees as durable solutions in those cases where repatriation or resettlement is not an option.

Access to citizenship of the host country is seen as a key element of refugees' integration into the host society and - in many cases - is a necessary precondition for the acquisition of electoral rights. At the same time, the principle of state sovereignty means that the regulation and complexity of citizenship regimes can vary widely among states. In any event, naturalization remains the only route to full and equal permanent membership of the political community. In addition, citizenship grants its holder an unconditional right to exit from and return to the territory of the state. Naturalization therefore constitutes the only status that irredeemably shields refugees from the risk of repatriation to their country of origin and allows them to settle permanently in their host country should they choose to do so. As such, free mobility rights are often cited as the main incentive for naturalization by refugees (Kuch 2017: 9), and more generally by migrants from developing countries (Harpaz 2015).

In most countries with an established route to naturalization, refugees are expected to meet certain requirements, such as passing formalized civic tests, having access to a minimum level of economic resources and proving that they have been legally residing in the host country for a certain number of years (Goodman 2012; Zetter 2007). More problematically, discriminatory treatment of refugees leads a number of countries to bar them access to the ordinary naturalization procedure, keeping them and subsequent generations outside the national community. By contrast, a number of countries have implemented provisions in their citizenship laws that offer privileged access to naturalization to refugees, in accordance with article 34 of the 1951 Refugee Convention as well as subsequent recommendations by the United Nations High Commissioner for Refugees (UNHCR) that host countries ought to provide a 'progressively wider range of rights and entitlements that are broadly commensurate with those enjoyed by its citizens and, over time, the possibility of naturalizing' (UNHCR 2005). In practice, this has been achieved by reducing or waiving the residence requirement (as in Sweden and France, respectively) for recognized refugees, or by waiving the requirement to renounce former citizenship (as in Austria, Bulgaria, Germany and Spain, among others) (EUDO Citizenship 2015). The impact of such preferential treatment should not be overestimated, however, as it often goes hand in hand with a tightening of eligibility conditions for refugee status and the proliferation of intermediate statuses offering periodically renewed 'temporary protection' visas (Durieux 2015). 


\section{Table 3. Naturalization requirements in host countries}

\begin{tabular}{|c|c|c|c|c|c|c|}
\hline $\begin{array}{l}\text { Host } \\
\text { country }\end{array}$ & $\frac{z}{\frac{\partial}{ \pm}}$ & 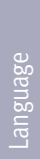 & 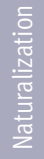 & 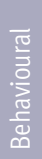 & $\begin{array}{l}\frac{\sqrt{\frac{U}{U}}}{\frac{E}{0}} \\
\text { 돈 }\end{array}$ & $\frac{\grave{c}}{\frac{5}{5}}$ \\
\hline Germany & 8 & $x$ & $x$ & $x$ & $x$ & $\begin{array}{l}\text { Residency requirement shortened to } 6 \text { years if good knowledge of } \\
\text { German shown; previous citizenship must be revoked }\end{array}$ \\
\hline Kenya & 7 & $x$ & $x$ & $x$ & $x$ & $\begin{array}{l}\text { Applicants must have the intention to stay and be able to } \\
\text { contribute to Kenya's development; in practice, naturalization is } \\
\text { not guaranteed to refugees }\end{array}$ \\
\hline Lebanon & - & - & - & - & - & $\begin{array}{l}\text { Citizenship through naturalization is not possible for refugees in } \\
\text { Lebanon }\end{array}$ \\
\hline $\begin{array}{l}\text { South } \\
\text { Africa }\end{array}$ & 15 & & & & & Meeting requirements does not ensure application approval \\
\hline Sweden & $4 / 5$ & & & $x$ & & $\begin{array}{l}\text { Residency requirement is } 4 \text { years for refugees, } 5 \text { years for other } \\
\text { resident aliens; without proof of identity, a refugee requires } 8 \\
\text { years of residency }\end{array}$ \\
\hline Turkey & 5 & $x$ & & $x$ & & Meeting requirements does not ensure application approval \\
\hline Uganda & 20 & $x$ & & $x$ & & $\begin{array}{l}\text { Applicants must have the intention to remain in the country; in } \\
\text { practice, acquiring citizenship through naturalization for refugees } \\
\text { is legally unclear and contradictory }\end{array}$ \\
\hline $\begin{array}{l}\text { United } \\
\text { Kingdom }\end{array}$ & 7 & $x$ & $x$ & $x$ & & GBP 1,282 application fee \\
\hline
\end{tabular}

Notes: Residency requirements expressed in minimum number of years. Naturalization requirements refer to naturalization tests. Behavioural requirements relate to a clean criminal record. Financial requirements relate to self-sustaining income.

$\mathrm{x}=$ element required in order to be eligible to apply for naturalization. Blank rows indicate that this element is not required.

This section examines the specific practices with regard to naturalization found in the host countries discussed in this report, the differences in their legal frameworks and practices, and how these affect refugees' opportunities to participate in formal political life. Table 3 provides an overview of the eight host countries examined in this report.

In the United Kingdom, the Home Office is responsible for all aspects of immigration and asylum, including applications for leave to remain. Granting leave to remain to an asylum seeker means official recognition as a refugee or permission to stay for 'humanitarian protection' or through 'discretionary leave to remain'. In most cases, this is granted for five years. After completion of the fiveyear period, there is an opportunity to apply for indefinite leave to remain (AIDA 
2016). Applicants for naturalization are required to be free from immigration restrictions for at least 12 months prior to their application. In respect of refugees, this would entail having been granted indefinite leave to remain for that period (Home Office 2017). Therefore, refugees in the UK have to wait a minimum of seven years from the moment they are granted refugee status until they become eligible to apply for naturalization. In addition, they have to pass a naturalization test on 'Life in the UK', meet English language and 'good character' requirements and pay a fee of GBP 1,282 (Home Office n.d.).

In particular, the requirement to 'be of good character' can be a significant barrier to naturalization for refugees who have entered the UK illegally and subsequently applied for asylum. There is evidence that non-compliance with the good character requirement was the main reason for the rejection of citizenship applications in the period 2002-2016, and made up 44 per cent of all refusals in 2016 (Blinder 2017). Furthermore, the language and UK knowledge requirements for naturalization seem to pose a greater burden on citizens of poorer, less educated and non-English-speaking countries, and may deter their applications (Ryan 2008). For example, Afghan applicants were at the bottom of the list of nationalities passing the naturalization test in the period October 2005-July 2007, with a pass rate of 47.2 per cent (Ryan 2008). Afghan women face significant additional challenges. Many among the Afghan-born female respondents interviewed for the UK case study were not educated in their home country and faced difficulties with their integration in the UK. Language difficulties and multiple pressures on women and girls to behave in a certain way limit their ability to engage in community activities (Change Institute 2009). All these pressures and constraints often leave Afghan women isolated until they are eligible to apply for British citizenship. Although reliable data on pass rates disaggregated by gender was not available, Afghan women are more likely to struggle with the language and literacy requirements of the naturalization test (Morrice 2017).

The jus soli (right of soil) British citizenship laws have traditionally been more open to naturalization compared to countries such as Germany which implement jus sanguinis (right of blood) principles. Nonetheless, it could be argued that the UK should be viewed as a jus soli country that is now less open to naturalization than other traditional jus soli countries, taking account of all the naturalization requirements for good conduct, language skills, cultural integration and years of residency, as well as the need to navigate complex and expensive application procedures (Blinder 2017).

In Germany, citizenship was historically granted on the basis of descent, building on an ethno-cultural understanding of the nation state. Nonetheless, through incremental changes Germany has moved away from this understanding of national belonging towards extending citizenship rights to immigrants. The Citizenship Act adopted in 1999 reduced the residence requirement from 15 
years to eight. In addition, applicants need to hold a permanent residence permit, must be in a position to independently ensure their livelihood without receiving social or unemployment assistance, and must be sufficiently proficient in the German language. Other requirements include the successful completion of naturalization tests, a commitment to the German Constitution and no convictions for criminal offences. Further amendments in 2007 reduced the required time of lawful residence for naturalization to six years if the applicant proves a high level of knowledge of the German language (Hailbronner 2010). It is important to note that Germany does not allow dual citizenship for firstgeneration, non-EU migrants. Hence, third-country nationals, including refugees who wish to apply, must give up their existing citizenship during the naturalization process (Staatsangehörigkeitsgesetz 2014, articles 8, 13, 16, 38). Legal reforms in 2014 introduced elements of jus soli for immigrant children, enabling them to hold dual citizenship provided that at least one parent is in possession of a permanent residence permit and has been residing in Germany for eight years (BGBl. I S. 1714). Previously, individuals had had to decide between the age of 18 and 21 which nationality they wanted to hold (Faist 2013).

In contrast, Sweden is the only host country examined in this report to have reduced residency requirements for the naturalization of refugees-four years of continuous residence, as opposed to the five years required for all other applicants. In addition, the applicant must have demonstrated 'good conduct' in Sweden and be able to provide proof of identity (Migrationsverket 2017). However, refugees who cannot provide proof of identity can be naturalized if they have been living in Sweden for eight years, as long as they are able to demonstrate that their stated identity is correct (Government Offices of Sweden 2015). This results in a longer residency requirement for certain nationalities of refugees. For example, the Swedish Migration Agency does not recognize Somali national passports or Somali documents issued after January 1991, including birth certificates and identity cards (Migrationsverket 2015). Hence, Somali refugees have to wait three years longer than other refugees before they can apply for Swedish citizenship.

In the case of South Africa, the minimum number of years of continuous residency required for refugees to become eligible for naturalization is 15 . According to section 7 of the Refugee Act, refugees can apply for a permanent residence permit after five years of continuous residence in the country, from the date they were granted asylum, provided that they have certification that confirms that the applicant is likely to remain a refugee for an indefinite period, based on several mitigating factors, including the continuing negative political and security situation in their country of origin. Once they have held a permanent residence permit for 10 years and fulfilled a set of other criteria as specified in the Citizenship Act of 1995, refugees can apply for naturalization. However, in practice, acquiring citizenship by naturalization is considered a privilege rather 
than a legal right. The minister may therefore refuse an application even if the applicant meets all the criteria (Isaacson 2008). The backlog of pending applications for asylum in South Africa constitutes an additional hurdle that results in the extension of the waiting period, since the residency requirements for naturalization only take into account the time spent in the country after asylum is granted. Some of the members and leaders of the Congolese community interviewed for the South Africa case study saw the prolongation of the asylum adjudication process as a strategy to limit the number of refugees in the country who will ultimately become eligible for citizenship through naturalization. Hence, the example of South Africa shows that even if the eligibility requirements for naturalization are clearly defined in law, in practice barriers such as extremely long waiting periods for the granting of asylum or refugee status significantly reduce the opportunities for refugees to obtain citizenship in their host country.

In the same vein, a combination of legal ambiguities blocks the pathway to Kenyan citizenship for refugees. According to the 2010 Constitution of Kenya (article 15), to be naturalized a person must be lawfully resident in Kenya for a continuous period of at least seven years and meet other conditions prescribed in the relevant legislation. The Kenya Citizenship and Immigration Act of 2011 (article 13) requires that in order to qualify for naturalization a person must have 'adequate knowledge of Kenya and of the duties and rights of citizens', have knowledge of Kiswahili or a local language and be able to make a contribution to Kenya's national development. In practice, however, naturalization is not granted to refugees (Garlick et al. 2015). According to a UNHCR evaluation in 2015, there is no great interest on the part of most refugees in becoming Kenyan citizens and the handful of individuals who had applied in recent years were still awaiting decisions on their applications. A representative of the Department of Refugee Affairs interviewed for the Kenya case study argued that a refugee seeking Kenyan citizenship must move from having refugee status to the status of 'non-Kenyan resident' as defined in the Kenya Citizenship and Immigration Act. According to this interpretation, the seven-year residence requirement would only start at the moment that the applicant received a residence permit as a non-Kenyan. He conceded that this law is unclear and needs to be reviewed, as even refugees who have been in Kenya for more than seven years remain ineligible for citizenship and hence cannot formally participate in Kenyan politics (Opon 2018). The need for a clear path to Kenyan citizenship and to promote understanding of the political rights of refugees was highlighted by a South Sudanese refugee in Kakuma: 'The Kenyan Government must push for the establishment of citizenship rights for refugees. We should be able to receive ID cards and become Kenyan citizens to have the same rights with the locals' (Opon 2018: 12).

Similarly, although Uganda has generally demonstrated a welcoming asylum policy, the government has been unable to offer a positive legal path to citizenship, which exacerbates the isolation long-term refugees feel in their host 
country (Hovil 2016). The inclusion or exclusion of refugees in or from the political fabric of Uganda is determined by their ability to gain citizenship. According to article 16 of the Uganda Citizenship and Immigration Control Act (UCICA), the legal requirements for naturalization are residence in the country for 20 years, adequate knowledge of a prescribed vernacular language or English, being of good character and the intention, if naturalized, to permanently reside in Uganda. However, the challenges around citizenship for refugees are rooted in the interpretation of contradictory legal provisions in the 1995 Ugandan Constitution, article 12(a)(2), and UCICA, article 14(a)(2), which states that a person residing in Uganda is only eligible for naturalization if 'neither of his or her parents and none of his or her grandparents was a refugee in Uganda'.

In 2010 these conflicts in the legislation led CSOs to seek clarification from the Ugandan Constitutional Court (UCC), in order to understand whether refugees can acquire citizenship by registration and/or naturalization. In October 2015 the UCC announced that although refugees cannot access citizenship through registration, because they have not 'voluntarily migrated' to Uganda as specified in article (2)(b) of the Constitution and article 14(2)(b) of the UCICA, they are eligible for naturalization. Since this ruling, however, there have been no successful cases of naturalization. This was confirmed by the Commissioner for Refugees, who was interviewed for the Uganda case study:

The Office of the Prime Minister has submitted a list of people [to the Ministry of Internal Affairs] we believe to be eligible for naturalization but championing this issue can be misconstrued and we need to be strategic with the timing. ... Elections and the economic dynamics of society play a role but we need to be active or we will end up with stateless populations.

—Commissioner for Refugees, Kampala, 2017 (Zakaryan 2018: 11)

This lack of a clear path to naturalization indicates a lack of long-term solutions for refugees, despite Uganda's proactive approach to hosting large numbers of refugees and asylum seekers. Further challenges to refugee naturalization are rooted in administrative processes for obtaining application forms and the lack of concise information on the administrative requirements of the naturalization process. Furthermore, refugees have reported approaching the National Citizenship and Immigration Board but being denied applications or told that they do not qualify (International Refugee Rights Initiative 2016). In this regard, a Congolese refugee in Nakivale stated: '[w] hen refugees ask Ugandan officials if we can naturalize, we are told it is a long and difficult process which we have to go to court for, but they don't explain how... we are just told "nationality is harder than resettlement"' (Zakaryan 2018: 13). 


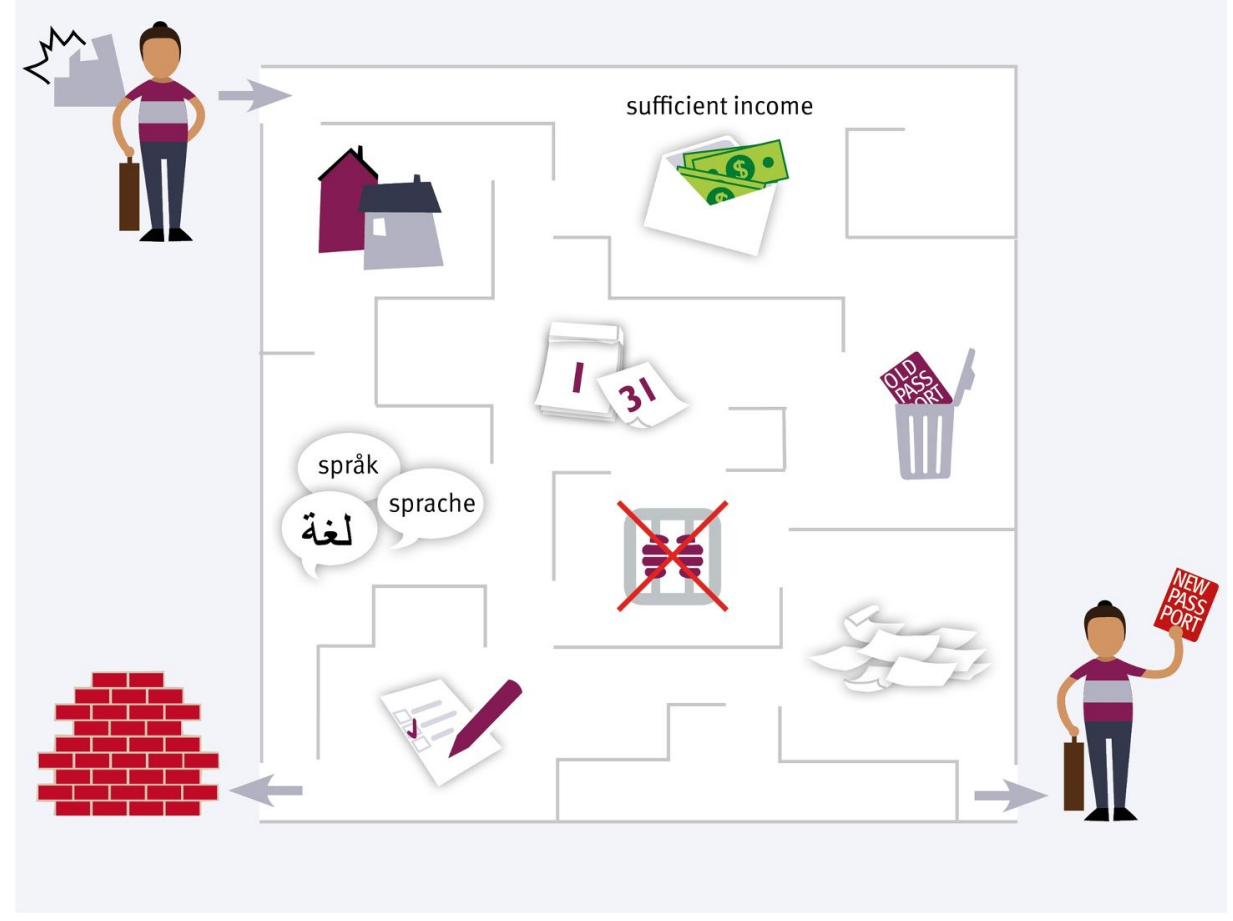

Figure 1. The path to naturalization

The importance of access to citizenship as a durable solution for long-term refugees from countries that are experiencing protracted conflict was highlighted by another Congolese refugee:

Repatriation cannot happen because people cannot return to places they no longer belong. ... I understand that most refugees are not receiving resettlement. ... I spent two years searching for Ugandan citizenship opportunities. ... No one was able to provide an answer and I kept being referred to Kampala. ... I met face to face with the Commissioner for Refugees, Kazungu Apollo, in an attempt to understand Ugandan refugee law and citizenship, just to learn there was no possibility.

—Congolese refugee 1, Nakivale, 2017 (Zakaryan 2018: 13)

The examples discussed above illustrate that the implementation of the 1951 Refugee Convention varies considerably among its signatory countries, as they 
have wide discretion when translating article 34 into domestic law and policy. The cases of Lebanon, which is not a signatory to the Convention, and Turkey, which has attached a geographic restriction to its ratification, offer even more dramatic illustrations of the challenges related to refugees' access to citizenship.

The Turkish Citizenship Act of 2009 includes a residency requirement of an uninterrupted period of five years. Furthermore, applicants must speak an 'adequate' amount of Turkish, have a self-sustaining income or profession and not be an 'obstacle' to national security. They may also have to relinquish previous citizenships. The Turkish Government can grant citizenship based on these requirements or otherwise on the decision of a 'competent authority', but none of this guarantees a positive decision on naturalization. Moreover, while children born to stateless parents are usually given Turkish citizenship automatically, this does not apply to births among Syrian refugees (Baladi 2015). Turkey is party to the 1951 Refugee Convention but due to a geographic restriction on its ratification it only considers displaced European nationals to be refugees. According to the Government, the more than 3 million Syrians who have fled to Turkey are under 'temporary protection' and considered 'guests of the state', rather than recognized refugees under the definition of the Convention.

Because such protection is supposed to be a temporary arrangement, public debate in the country becomes heated when the discussion turns to naturalization and long-term integration (International Crisis Group 2016). Political parties and politicians tread a careful line between being seen as welcoming of their 'guests' and opposing the potential economic and political disruption of granting citizenship en masse. For instance, in 2016 the Turkish President, Recep Tayyı Erdoğan, publicly supported giving citizenship to Syrian refugees, but did not specify any eligibility requirements (Al Jazeera 2016). He stated that this provision would apply to those with high-level professional skills (Al Jazeera 2017a). The subsequent backlash became one of the top-trending topics on Twitter at the time (Girit 2016). The two main opposition parties, the Republican People's Party (Cumhuriyet Halk Partisi, CHP) and the Nationalist Movement Party (Milliyetçi Hareket Partisi, MHP), opposed the idea, arguing that citizenship would discourage Syrians from returning home and that the policy discriminated against less qualified refugees (Hurriyet Daily News 2016a). They also felt that the ruling party was seeking to benefit from grateful refugees. In contrast, the leftist pro-Kurdish People's Democracy Party (Halkların Demokratik Partisi, HDP), a pro-government newspaper and at least one academic scholar argued that the policy was intended to reduce the demographic influence of the Kurdish population in the south-east (Çetingüleç 2016). Instead, the HDP advocated granting Syrians internationally recognized refugee status (Hurriyet Daily News 2016b).

In this respect, the Syrians interviewed in Turkey for this report did not necessarily consider access to Turkish citizenship a durable solution, given that 
most saw their presence in Turkey as temporary and expressed a low sense of belonging to Turkish society. When asked in which country they planned to settle, all but one indicated that Turkey was a stopover for either Europe or North America, or that they ultimately wanted to return to Syria. One Syrian male refugee and humanitarian worker in Gaziantep noted that: 'Turkey is not my country. I don't feel any moral obligation [to participate in Turkish politics] . . . if I were given the right to vote, I would have to stay in the country, but I don't want to stay here' (Mannix 2018: 13).

Lastly, the case of Lebanon is an example of a country where naturalization is not a legal process open to all who live in the country, but results from an ad hoc presidential decree, which is rarely issued. Although refugees make up approximately 25 per cent of the population of Lebanon, mostly Palestinians and Syrians, they are excluded from Lebanese citizenship. At the same time, Lebanese women married to foreigners are unable to extend their nationalities to their husbands or their children-even if they have been born and raised in Lebanon. Lebanese politicians have recently openly opposed any possible permanent settlement of Syrian refugees in Lebanon (Francis 2017). In 2017 Lebanon's Foreign Minister, Gebran Bassil, reiterated his position that Lebanon will not naturalize Syrian or Palestinian refugees living in the country (Daily Star 2017).

However, it is interesting to note that 154,931 foreign residents, including more than 65,000 Syrians, were naturalized in Lebanon in 1994. Among those naturalized were a number of non-registered individuals and families living on the border between Lebanon and Syria. The procedure was considered controversial because it was carried out while Lebanon was occupied by the Syrian Army. A large number of naturalized Syrians were registered in districts where politicians wanted to secure votes. The naturalization decree also benefited a number of families of various nationalities who had been living in Lebanon for a long time, which meant that their naturalization was overdue. In the 1996, 2000 and 2005 elections, and the 2007 by-elections, these naturalized citizens demonstrated a higher rate of voter participation than the native-born population (Hourani and Sensenig-Dabbous 2011). In 2011, six years after the withdrawal of Syrian forces from Lebanon, a presidential decree was issued seeking to withdraw Lebanese nationality from individuals who were allegedly naturalized unconstitutionally or based on false documents (Naharnet 2011). The decree was never implemented, however, so those Syrians who were naturalized retain their Lebanese nationality. Nonetheless, the Lebanese example gives credence to the thesis that there is a trade-off between numbers and rights: a large number of refugees encourages the host country to downgrade their status or to restrict their opportunities to access citizenship and ultimately to obtain equal electoral rights to citizens (Thielemann and Hobolth 2016).

As the cases examined above show, the route to naturalization is left to the discretion and the different legal frameworks of the host countries concerned. 
While host countries are encouraged by international law to facilitate refugees' integration through naturalization as a durable solution, they remain sovereign in matters of defining stricter or more favourable criteria for naturalization. Refugees are often seen by their host countries as a temporary burden, whose long-term future consists of repatriation to their country of origin rather than naturalization (Chimni 2004). Therefore, host countries often remain reluctant to take measures that would expand their political rights or encourage their integration into the political and national community (Kuch 2017).

\section{Access to electoral rights and political parties}

If you can't vote, you can't have a say on issues that directly affect your present and future life.

—Afghan male refugee 1, West London, 2017 (Sharifi 2018: 12)

While voting is not the only meaningful channel for political participation through which refugees and asylum seekers can make their voices heard and have their interests represented in the host country, it is widely considered the core component of democratic citizenship, and an essential requirement for a political system to be deemed fully democratic (Dahl 1989: 130). Do refugees have the right to participate in formal decision-making in host countries? If so, what are the opportunities and challenges with regard to their participation in formal political institutions and processes, including elections and political parties? National electoral laws rarely treat refugees as a special category of resident noncitizens in need of otherwise citizenship-contingent electoral rights (Arrighi and Bauböck 2017). As the case studies illustrate, electoral rights are usually reserved for citizens or extended only to special categories of resident non-citizens, such as EU citizens in the case of Germany and citizens of the former Commonwealth countries and the Republic of Ireland in the case of the UK (see Table 4).

Sweden is the only case in which all resident non-citizens, including refugees, are eligible to vote in regional and municipal referendums and elections, and to stand as candidates in regional and municipal elections. According to the Swedish Local Government Act 2004, refugees must have three years of continuous residence in Sweden before election day (2004: 31). To exercise their right, eligible voters must be included on the electoral roll (Bernitz 2013). Sweden extended municipal and provincial voting rights to resident non-citizens in 1976, arguing that it would boost their political influence, interest and self-esteem. The main arguments in favour of this measure were those of equal participation and political inclusion, and to encourage a feeling of having a stake in society. 
Table 4. Electoral rights in host countries

\begin{tabular}{|l|l|l|}
\hline Host country & Local elections (municipal, provincial) & National elections \\
\hline Germany & Only German and EU citizens & Only citizens \\
\hline Kenya & Only citizens & Only citizens \\
\hline Lebanon & Only citizens & Only citizens \\
\hline South Africa & Only citizens & Only citizens \\
\hline Sweden & Non-citizens resident for 3 continuous years & Only citizens \\
\hline Turkey & Only citizens & Only citizens \\
\hline Uganda & Only citizens & Only citizens \\
\hline United Kingdom & Only British, EU or qualifying Commonwealth citizens & $\begin{array}{l}\text { Only British, Commonwealth or } \\
\text { Republic of Ireland citizens }\end{array}$ \\
\hline
\end{tabular}

However, the mere fact of being entitled to vote or stand as a candidate does not mean that refugees will actually exercise their electoral rights. Unfortunately, data on refugees' electoral behaviour is sparse, as electoral administrations do not usually disaggregate ballots cast by eligible voters from a refugee background from other resident non-citizens. Similarly, measuring refugees' relative representation in local, regional or national parliaments is made remarkably difficult by the fact that most countries do not gather statistics based on ethnicity or elected members' previous legal status (Bloemraad 2013). Despite these constraints, available research on immigrants' electoral participation consistently shows a turnout that is considerably lower than that of the native-born electorate, even when controlling for the age and class variables that are the best predictors of political participation (Ruedin 2017).

A similar conclusion can be drawn regarding the share of elected representatives with an immigrant background, based on evidence of pervasive and substantial underrepresentation that is less pronounced at the local level but grows wider in national parliaments and governments (Bloemraad 2013; Morales and Giugni 2016). The question of whether the enjoyment of electoral rights translates into actual mobilization is central and is systematically addressed in the case studies conducted for this report.

In Sweden's 2014 municipal council elections turnout among voters with Swedish citizenship was 85.9 per cent, whereas only 46.1 per cent of eligible voters holding the citizenship of an African country and 29.1 per cent of eligible voters from an Asian country cast a ballot. In the 2014 legislative elections the turnout among naturalized Swedish citizens was 72.8 per cent, as opposed to 89.2 per cent for native-born eligible voters (Statistics Sweden 2014). Although there is 
no statistically reliable data on the proportion of voters from a refugee background, analysis of the qualitative data gathered through interviews and focus group discussions with Syrian and Somali refugees in Sweden identifies various factors that contribute to the low level of electoral participation by refugees. These include refugees' experiences in their countries of origin; their length of stay in the host country; and their educational level, gender, age and class.

An additional aspect to consider is that the number of foreign-born voters in Sweden increased considerably between 2010 and 2014 and the tendency to vote is lower among those who have only recently been awarded Swedish citizenship (Statistics Sweden 2015). For example, the majority of the Syrian respondents were new arrivals and had resided in Sweden for between one and five years. At the time of the research they were still struggling to establish themselves, find jobs and housing, and learn the language. Hence, they were primarily concerned about their current living conditions, the conflict situation in Syria and other pending administrative issues related to their status as refugees. By contrast, the majority of Somali respondents had been residing in Sweden for more than five years and had either obtained permanent residency or acquired Swedish citizenship. Many acknowledged the importance and the implications of exercising their voting rights. For instance, one naturalized refugee from Tensta-Spånga in Stockholm noted: 'If you get the right to vote, you have to exercise it, because it doesn't only affect you but a whole nation' (Adan 2018: 12).

The Afghan respondents interviewed in the UK represented a mix of those who had arrived in the country 10 years or more before and recent arrivals who would not have had the opportunity to integrate completely into British society. For this reason, their political participation varied to a great degree, between the naturalized Afghan-born residents and those who were still awaiting a decision from the Home Office. In addition, among the group of naturalized Afghans eligible to vote and stand in national and local elections, the case study found gender-based differences between the men, who are more politically involved, and the women who tend to deal with 'family matters'.

Nearly all of the Afghan-born refugees with British citizenship interviewed had voted in the past two elections in the UK and were either supporters or active members of a British political party, usually the Labour Party. However, many of the female Afghan-born British citizens interviewed were either unaware of politics and the civic activities in their surrounding areas, or too caught up in other aspects of their daily lives - mostly confined to the home-for politics to be a priority. Many confirmed that they had voted on election day, but that they were encouraged by a male family member to vote for a particular candidate. According to a representative of an Afghan union organization: 
Afghan women are under the influence of men.... Their male family members, often their husbands, keep them uninformed and uneducated about social and political matters in their surroundings. Some men feel very insecure if their wives learn about British values or if they try to integrate in the host community.

—Representative of an Afghan union organization, London, 2017 (Sharifi 2018: 12)

Similarly, female Somali respondents in Sweden underlined the need for adequate information and education about civic and political rights and the political system in the host country to enhance their understanding of the political system and realize their potential to participate in political life at all levels. According to one Somali naturalized female refugee in Rinkeby, Stockholm:

It is very important to learn how the democratic system works. Many people like me don't understand the meaning of democracy. There is no voting system in my home country and lack of knowledge of the Swedish language is a big barrier to the integration of refugees into all aspects of the host society.

—Somali naturalized female refugee 2, Rinkeby, Stockholm, 2017 (Adan 2018: 15)

The need to receive civic education and adequate information about the host country's political system at an early stage after arrival was also highlighted as an important condition for the effective exercise of electoral rights by Syrian respondents in both the Turkey and the Sweden case studies. They noted that they had little or no experience of participating in democratic processes in their country of origin. In particular, Syrians interviewed in Turkey expressed a desire to gain a better understanding of the ideologies, practices and histories of the political parties there, as well as of the public debate around the different party platforms in order to make informed choices as potential voters: 'Right now there is a lack of political knowledge. If I had the time to study the parties and their platforms, I would vote' (Mannix 2018: 13).

A lack of awareness among refugees of their political rights in their host country was also singled out by the vast majority of Afghan interviewees in the UK, who acknowledged that they came from a country with little or no experience of participation in democratic institutions and processes. Integration into a very old democracy with a rich and diverse political system would be impossible without proper civic education to inform and encourage refugees to 
learn about the host country's political system and the different mechanisms for political participation. For example, one refugee in Manchester argued:

In the early months and years after arrival, refugees and asylum seekers have more time and more motivation [to learn] about integration into the host country's civic and political community. Years of disengagement due to lack of voting rights isolates them and even after they have obtained British citizenship, the system would sound alien to them.

—Afghan male refugee 9, Manchester, 2017 (Sharifi 2018: 15)

Indeed, there is a growing body of evidence that early investment in integration programmes is key to the successful long-term incorporation of refugees into the cultural, economic and political institutions of host countries (Hainmueller, Hangartner and Lawrence 2016). Providing refugees with early access to integration programmes and opportunities to rapidly become full members of the political community in their host countries is also seen as an effective way of avoiding the detrimental consequences of marginalization (Milner 2014).

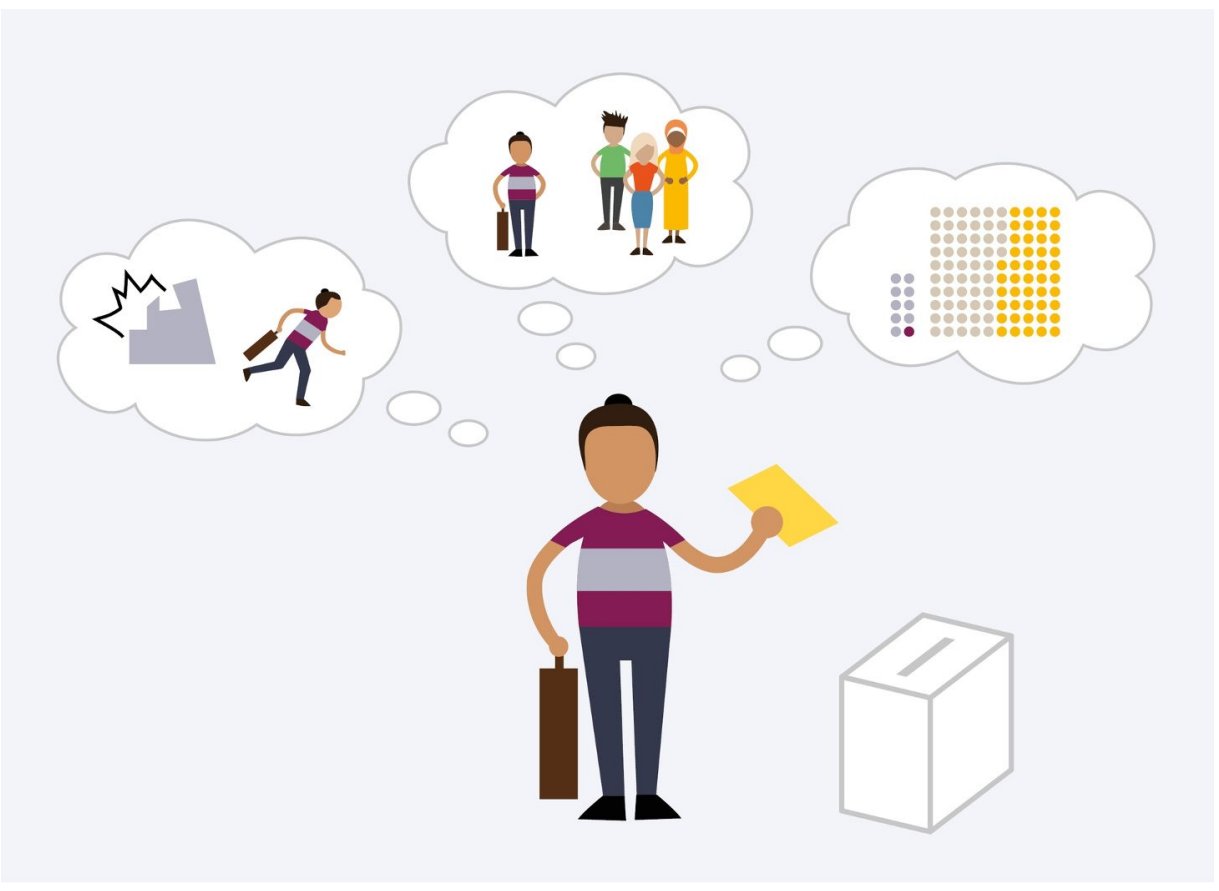

Figure 2. Challenges to refugees' formal political participation in host countries 
Another factor that can deter refugees from participating in the formal political life of their host country is their prior experience of politics in their country of origin. Refugees might have had a negative experience of politics back home, or might have been personally subjected to persecution at the hands of the government. Any desire to get involved in politics in their host country would therefore be a low priority. This was emphasized in the case of Afghans in the UK. Most of the respondents who were active as members of political parties or candidates in local elections were in their 20s or 30s, which means that they were too young to participate in any political activities during the civil war or Taliban rule in Afghanistan. The head of an Afghan refugee support organization interviewed said that unpleasant experiences back home, such as imprisonment, assassination and harassment of members of certain political parties and politicians, often led the older generation of Afghan refugees to believe that supporting a political party could have dire consequences even in the UK (Sharifi 2018). Therefore, many older Afghans seemed reluctant to directly engage with political parties. Unlike those who were 50 or over, those under 35 seemed to be more involved in British politics. For instance, Paimana Asad was three years old when she left Afghanistan and came to the UK with her parents. She was brought up in England and is now an active member of the Labour Party in north London. In an interview with BBC News Persian before the 2015 British general elections, she said that it was the lack of attention paid to Afghan refugees by local authorities that politicized her: 'Afghan politics are leader-centric but British politics are more party-centric. Therefore, political practices do not make sense for older Afghans here. A lack of interest in and exposure to home politics has helped the younger generation of refugees and asylum seekers show a greater interest in host country politics' (BBC News Persian 2015).

Notwithstanding the legal restrictions on the right to vote and stand as candidates experienced by refugees in the majority of the host countries discussed in this report, participation in and membership of political parties was highlighted as an important means of participation in the host country's political life. The legal frameworks regulating membership of and participation in political parties vary widely across the different case studies. On the one hand, political parties in Sweden and the UK, as well as some parties in Germany, allow noncitizens to become members, irrespective of their legal status as refugees. On the other hand, in the cases of Kenya, South Africa, Turkey and Uganda, refugees' opportunities to become members of political parties are extremely limited, since citizenship is a constitutional or legal requirement for party membership, or in the case of Lebanon due to practical barriers.

The South African Constitution grants citizens the right to form a political party, stand for public office, recruit, campaign or participate in the activities of a political party and vote for legislative bodies. Although in theory this does not mean that non-citizens are restricted from joining political parties, the 
constitution does not protect their right to do so. Furthermore, Chapter 1 of the Electoral Act of 2013, which applies to elections for the National Assembly, provincial legislatures and municipal councils, defines a voter as a South African citizen who is 18 years old or over, and whose name appears on the national common voters' roll. The Act clearly prohibits the Chief Electoral Officer from registering anyone who is not a South African citizen on the voters' roll. Furthermore, only registered parties that have submitted candidate lists can contest elections in South Africa. Candidate lists are accompanied by an undertaking that each candidate is qualified to stand for public office according to the terms of the constitution. South Africa's Electoral Commission Act also reinforces citizenship as a requirement for political party registration because one of the requirements for registration is that the party's deed of foundation must be signed by a prescribed number of qualified voters. Therefore, migrants, including refugees and asylum seekers, cannot formally hold a position in or form a political party or stand for office unless they acquire South African citizenship and thereby gain a different legal status.

Membership of some political parties is only open to South African citizens. One example is the Inkatha Freedom Party (2012). The official opposition in parliament, the Democratic Alliance, extends membership to South African citizens and permanent residents (Democratic Alliance 2015). However, the African National Congress (ANC), the largest and current ruling party in South Africa, opens its membership to South Africans who are 18 years or older and all other persons who identify with South Africans and reside in South Africa. Its National Executive Committee can also grant honorary membership to people outside of these requirements (ANC 2012). This latter category is interesting because membership presumably allows all individuals the same opportunity to hold various leadership positions in the party, including chairperson and president. Established practice suggests that those who hold such senior positions in political parties would automatically be nominated for a leadership position in the National Assembly and by extension could rise to hold a position in the country's executive leadership. However, the Constitution makes such progression impossible because if they are not citizens, members cannot represent their political party in public office, including the National Assembly or provincial and local levels of government. None of the refugees interviewed for this research were members or active supporters of any South African political party, even if some did have a degree of sympathy or preference for certain parties. Some respondents expressed support for opposition parties, whose members sometimes participated in their protests, for example in marches against xenophobia.

In the same vein, non-citizens in Kenya, including refugees, are not entitled to become members of a political party, as there is a legal requirement to be a registered voter in order to be granted party membership. Therefore refugees 
cannot join political parties until they have been naturalized. Somali and South Sudanese refugees interviewed in Kenya overwhelmingly denied any type of engagement in or support for Kenyan political parties. Furthermore, several participants felt that their refugee status excluded any involvement in the political issues of their host country: 'As a refugee, I have no right to talk about the political issues of Kenya' (Opon 2018: 12). Further challenges stem from the fact that many refugees arriving in Kenya have negative experiences of political processes in their countries of origin. According to a legal expert on refugee rights interviewed in Nairobi, this leads to fear of political stigmatization and no desire to participate in the politics of the host country (Opon 2018: 12). This was evident from the focus group discussions in Kakuma refugee camp in Kenya, and more so among South Sudanese refugees.

In Uganda, where there are also legal restrictions on refugees' access to political parties, one South Sudanese refugee in Kampala described how when he was a student in Arua District, he had supported a local member of parliament. Given his refugee status, he was not able to vote for the candidate or publicly express support, so he organized fellow Ugandan youths to attend the candidate's rallies. He was motivated by the candidate's profession as an engineer, and the fact that he had promised to build a dam that would generate power for both Uganda and South Sudan (Zakaryan 2018).

In the case of Syrians in Turkey, more than 80 per cent of the Syrian participants interviewed for this study denied any implicit or explicit support for any Turkish political party. The inclusion of refugee issues on the agendas of Turkish political parties and the adoption of policies that would improve the situation for refugees emerged as important determinants of refugees' future voting preferences. A Syrian male refugee English teacher in Istanbul stressed that he would vote for any party that brought 'something to the table' for refugees (Mannix 2018: 13). Furthermore, several participants highlighted that their party preferences would be affected by a party's ability to accomplish public works projects and deliver services. Refugees' ethnic and religious backgrounds, and their flight histories, also played a role in their engagement with Turkish political parties. For instance, one respondent who identified as Kurdish informally supported the pro-Kurdish HDP, while another Gaziantep-based refugee from Idlib who had escaped from the Islamic State in Iraq and Syria (ISIS) supported the centre-left secularist Republican People's Party because of its commitment to the separation of church and state. However, the majority of participants claimed that no Turkish political party reflected their interests (Mannix 2018: 14).

In a similar way, interviews with key informants in Lebanon showed that there is very little room for Syrian refugees to join Lebanese political parties. They can, however, unofficially support certain political parties. For example, many of the Syrians who support the Assad regime are also supporters of Hezbollah, since Hezbollah is fighting in Syria with the regime and against opposition militants 
(Wight 2017). There are also some cross-regional and cross-sectarian political parties, such as the Lebanese Communist Party, the Syrian Social Nationalist Party (SSNP) and the Baath party. The latter two are pan-Arab parties. The Baath party in Lebanon is the Lebanese chapter of the Arab Baath party, which rules Syria. The SSNP, founded in Beirut in 1932, believes in the Syrian Nation along a 'fertile Crescent' that includes Cyprus, Iraq, Jordan, Kuwait, Lebanon, Palestine and Syria (SSNP 2017). However, most political parties in Lebanon are very much constituency-based, and most constituencies are homogenous in terms of sectarian and/or regional belonging. Many of these parties do not even appeal to Lebanese citizens outside their closed constituencies. Hence, Syrian refugees are not concerned with joining any of these parties, especially if they are not considered part of the closed group and would not identify with the political narratives of the party.

In general, it is expected that Syrian refugees will not take part in Lebanese politics, as this would be considered foreign interference in Lebanon's internal affairs. As a Syrian male political activist in Beirut interviewed for the Lebanon case study noted:

Syrian refugees are not engaged in Lebanese political parties. There is a kind of caution on behalf of parties about involving Syrians, because this might eventually be seen as Syrian interference in Lebanese internal politics, which is unwelcome. In addition, there are no new players on the Lebanese political scene, and old parties do not want to bring any change to the status quo.

- Syrian male refugee and political activist 1, Beirut, 2017

(El-Helou 2018: 13)

It is also important to keep in mind that Syrian activists have been arrested in Lebanon, which is a significant deterrent to Syrian refugees becoming politically active: 'Syrian refugees in Lebanon do not take positions in relation to Lebanese politics. They would rather keep a low profile in order to avoid getting into trouble' (El-Helou 2018: 13).

In contrast, Sweden, the UK and, to a lesser extent, Germany provide a number of opportunities for refugees to join or support political parties in the host country. For example, in Sweden any legal resident non-citizen, including refugees with permanent residence permits, can join any political party of their choice. Party membership can be requested using online forms or by visiting the local party office. In certain cases, political parties have adopted voluntary quotas to increase internal diversity. For instance, the Social Democratic Party (Socialdemokraterna, SAP) has introduced quotas for candidates with nonNordic immigrant backgrounds, including refugees. In the 2014 general 
elections, one in every four candidates on the SAP list in the electoral district of Stockholm was from an immigrant background. These quotas are seen as an instrument for implementing the party's commitment to increase the number of politicians from an immigrant background and as a means of rectifying the underrepresentation of immigrants in political life (Dähnke et al. 2014). During the focus group discussions with Somali refugees in Sweden, many participants agreed that the process of becoming a member of a political party in Sweden is very simple and open to all, regardless of the potential member's legal status as refugee or citizen. A naturalized Somali member of the City Council and the SAP in Malmö noted: 'There are a lot of refugees and other immigrants who are active members of the SAP. A person can be either a regular or an active member. To be an active member, one must pay SEK 240 per year. This is to show your commitment to the party and the fee is also part of the financial contribution to the party' (Adan 2018: 14).

In addition, a Somali naturalized refugee in Stockholm underlined the value of active membership of political parties:

I have been a member of the Moderate Party for more than five years, which has given me a lot of experience through my activities as a youth activist in the party. I acted as party recruiter for more than one year. I never had any problems in the party. On the contrary, my active participation as a party member gave me a lot of opportunities to grow personally and professionally.

—Somali naturalized refugee 3, Stockholm, 2017 (Ragab 2018: 16)

Nonetheless, a majority of the respondents from both the Syrian and the Somali refugee communities interviewed in Sweden noted that, even though there are no restrictive laws and membership requirements, there is still a representation gap. Being a politician with an immigrant background may offer a way into politics but can in the long run present difficulties for advancement. It is widely acknowledged in political circles that internal and external networking and connections are very important. Refugees who lack an internal network or connections during a party's nomination process find it very difficult, if not impossible, to break through (Bevelander and Spång 2017). Indeed, candidates with a refugee background are often placed in unfavourable positions on party lists, with little or no possibility of getting elected. Such discriminatory practices by party gatekeepers contribute to a large extent to the underrepresentation of refugees in formal political institutions (Dancygier et al. 2015). Although immigrants', including refugees', representation in political assemblies has increased in recent decades, the foreign-born population in Sweden is still underrepresented (Bevelander and Spång 2017). At the 2010 municipal elections, 
foreign-born candidates made up 9.1 per cent of the candidates. By the 2014 elections this figure had increased to 9.7 per cent. A slight increase has also been observed in the number of foreign-born municipal councillors, from 7.6 per cent in 2010 to 7.7 per cent in 2014 (Valmyndigheten 2014).

A similar conclusion can be drawn from the case of Germany. While all the parties represented in the German Parliament (Bundestag) allow membership by non-German citizens, membership by non-European migrants of the Christian Democratic Union of Germany (Christlich Demokratische Union Deutschlands, CDU) is limited to guest status (Bündnis 90/Die Grünen 2016; CDU 2016; Die Linke 2016; SPD 2017). The Christian Social Union (Christlich-Soziale Union, CSU) allows membership by third country nationals only if that person has lived in Germany for at least three years (CSU 2016). Although the proportion of parliamentarians of immigrant-origin has been steadily rising, only 37 members of the national parliament (5.9 per cent of all members) had a migrant background in 2013 (Mediendienst Integration 2013). This figure increased after the 2017 elections, when 57 members from an immigrant background were elected to the national parliament, which accounts for 8 per cent of all national MPs (Mediendienst Integration 2017). An older study on council membership in large German cities found an increasing number of council members from a migrant background on German city councils. Nonetheless, given that in the period September 2006 to March 2011 only 4 per cent of the 4,670 council members were of migrant origin, this does not reflect the diversity of the German urban population. On average, migrants account for about a quarter of the population in the largest cities. Refugees and asylum seekers are even less well represented. Only 8.6 per cent of the council members from a migrant background surveyed indicated that forced displacement was their reason for migration (Schönwälder, Sinanoglu and Volkert 2011).

For the Afghan and Syrian respondents in the Germany case study, besides voting, party membership was seen as another way to participate in the political life of the country. Four of the Afghan respondents were members of the Social Democratic Party of Germany (Sozialdemokratische Partei Deutschlands, SPD), but no Syrian respondents were party members. The reasons for joining a German political party were diverse, and family background was explicitly mentioned by those who had recently arrived in Germany. Being politically socialized as well as previous political engagement in their country of origin, but also the opportunity to gain experience in democratic practices, were cited as important motivating factors. A male representative of an Afghan refugee organization in Berlin told how: 
I thought, I am here now and I would like to continue working in politics and I also want to study politics, so I thought it might be better to join a party. [...] I learn a lot about German politics and parties, but also about German culture. [...] Politics is my goal, my blood, I cannot live without politics. I have grown up with politics. Also because of the problems of my country, my country needs someone to help.

-Afghan male representative of an Afghan refugee organization 1, Berlin, 2017 (Ragab 2018: 16)

Those newly arrived stated that their choice of party was influenced by the active stance of some SPD politicians with regard to the increasing number of people seeking protection in Europe. Furthermore, the party's agenda on immigration and migrants' rights, as well as positive perceptions of the party's policies on social justice, were among the primary reasons for joining the SPD. However, while Afghan party members tried to influence both internal and foreign policy through active lobbying, they perceived that their voices were ignored by German politicians (Ragab 2018: 16).

On the positive side, in the UK any resident can become a member of a political party or form a political group. British political parties' requirements for membership vary, and the most 'nationalistic' parties are perhaps surprisingly among the most open to foreign supporters (Ferguson 2015). Some British political parties, such as the Scottish National Party, the UK Independence Party, the Green Party and the Liberal Democrats, allow potential members living anywhere in the world to join, regardless of whether they are UK citizens. The Conservative Party only accepts UK residents, but does not require members to hold British citizenship. The Labour Party, which has the highest number of members and highest number of non-British born members, is the strictest with regard to membership. It only admits British or Irish citizens, or residents who have lived in the UK for at least one year (Ferguson 2015).

The fact that refugees can join a political party even without the right to take part in elections meant a lot to many Afghan refugees interviewed in the UK, as it has provided a basis for the exercise of their political rights. An Afghan refugee and member of the British Labour Party stated that those deprived of voting rights could still achieve what a voter might simply by joining a political party: 'I may be deprived of my right to vote but as an active member of the party of my choice whose manifesto has been discussed with me, I campaign and earn so many votes for the party. The main goal is to make the party win' (Sharifi 2018: 14).

Most of the older generation of Afghan refugees and asylum seekers interviewed for this study believed that taking part in elections or supporting a 
political party of their choice would protect or improve their current socioeconomic circumstances. In addition, the younger generation of Afghan refugees and asylum seekers saw political integration and civic engagement as a way forward to break into the British socio-political hierarchy and, like other migrant nationalities such as Indians, become decision-makers at the local and national levels in the UK. One Afghan male refugee in London, a former Labour Party candidate, argued: 'You are only recognized by the size of your voting community and when you are represented on an important political platform' (Sharifi 2018: 12).

The UK does not currently have any Afghan-born members of parliament or elected local councillors. Nonetheless, there are many Afghan refugees across the UK who are full members of a political party and some have stood as candidates for political parties in local council elections. As she prepared her door-to-door campaign for a Labour Party candidate in a north-west London borough during the June 2017 general elections, a young Afghan Labour Party member argued that: 'You are only as dominant as the size of your politically active community; you only matter if you are seen as a good-sized community of potential voters'. Her advice for eligible Afghan refugee voters was as follows:

Our individual or common problems can only be heard and addressed by a local MP if he or she is convinced that we can deliver him or her votes when it is needed ... Afghan refugees' mentality towards British elections has improved quite a lot. Five years ago, when I was running for local council elections in this borough, people were not even prepared to listen to me when I knocked on their doors. Although I did not earn enough votes to win that time, my appearance changed their minds.... The second generation of Afghan refugees is far more vibrant and interested in politics now.

-Afghan female refugee 2, former Labour Party candidate, London, 2017 (Sharifi 2018: 13)

For many refugee respondents across the different case studies, being involved socially, politically and culturally in the host society was seen as an important aspect of inclusion and belonging, particularly since for many, a sustainable return in the near future or a cessation of conflict in their countries of origin seemed unlikely. Hence, refugees' access to electoral rights should not be seen as the end point and reward for a successful process of integration, but as an instrument facilitating integration itself (Ziegler 2017: 215-17; Huddleston and Vink 2015). This argument naturally leads beyond the issue of the democratic legitimacy of the overall political system of the host country to consider the benefits of active citizenship for refugees (Ebead and McDonough 2017). 
Enjoying the right to vote has an intrinsic value, as it acknowledges refugees' symbolic membership and sense of belonging to the political community for the duration of their stay in their host country. Moreover, it serves the instrumental purpose of encouraging refugees to invest in the acquisition of local political norms and knowledge, a process that can also be facilitated by their inclusion in political parties. 


\section{Non-formal political participation of refugees in their host countries}

A lack of citizenship or legal status should not mean that refugees have no voice in the political, economic and social affairs of their host country. In fact, groups such as refugees, who are often excluded from formal political activities, have an even greater need for alternative means of political participation (UN Human Rights Council 2014). The UNHCR Zero Draft on Refugees calls on states and other relevant stakeholders to 'include refugees, particularly women and youth, in key fora, institutions, and decision-making processes' and to 'support consultative processes that enable refugees and host communities to assess their own needs and help to design appropriate responses' (UNHCR 2018). In addition, the Zero Draft of the Global Compact for Safe, Orderly and Regular Migration (UN 2018) recognizes migrants' political participation as an important component of their integration into host societies, acknowledging that 'fully integrated migrants are better positioned to contribute to prosperity' (Objective 16).

When formal political participation is not possible, or is hampered by legal and practical constraints, refugees may rely on less formal means of engagement to make their voices heard. In many host countries, they may count on the support of a well-entrenched network of associations, religious and non-religious charities, and civil society to provide them with day-to-day assistance and advocate for an extension of their rights. Since opportunities for formal participation in the decision-making institutions and processes of their host countries are often restricted, refugees often resort to non-formal mechanisms of political participation to defend what they perceive as their interests. This leads on to a consideration of the range and degree of non-formal mechanisms of political 
participation in host countries. It is possible to distinguish between at least three means of non-formal political participation: (a) consultative bodies; (b) CSOs; and (c) protests and grassroots initiatives. Each can have an important political value and make an impact on the political life of the host country.

\section{Consultative bodies}

In Europe, consultative bodies were initially introduced to compensate for the absence of formal means of political participation for the general population of resident non-citizens. The issue figured prominently in the debate preceding the adoption of the Council of Europe's 1992 Convention on the Participation of Foreigners in Public Life at Local Level. Article 5 of the Convention, which entered into force in 1997, provides that contracting states should: 'encourage and facilitate the establishment of consultative bodies or the making of other appropriate institutional arrangements for the representation of foreign residents by local authorities in whose area there is a significant number of foreign residents' (Council of Europe 1992). Consultative bodies at the national or local level were perceived as a measure for fostering structured dialogue between immigrant groups and governments. Recent research by the European Union Fundamental Rights Agency found consultative bodies operating at the local or regional level in several EU member states, such as the Czech Republic, Denmark, Germany, Greece, Finland, France, Ireland, Italy, Latvia, Luxembourg, Poland and Spain (EU FRA 2017). Although the structure, composition, functions and mandates of consultative bodies differ significantly across the various host countries, they are established based on the central idea of enabling representatives of migrant groups to consult with national or local authorities on issues that affect them. Of the eight host countries examined in this report, consultative bodies were found in Germany and Uganda.

In Germany, the strict citizenship regime combined with a political franchise reserved for citizens has created a large population of disenfranchised people among not just the immigrant population, but also their descendants born and raised in Germany. Given the lack of opportunities for traditional forms of democratic participation, foreign advisory, migration and integration councils (Ausländer-, Migrations-, Integrationsbeiräte) have been established in various German cities and municipalities since the mid-1970s to ensure political representation of migrants at the local level. Regulation of the formation of these consultative bodies is governed by the different constitutions of the German federal states. Berlin, Bremen, North Rhine-Westphalia (NRW) and Hesse oblige municipalities with a certain proportion of non-German citizens to establish migrant advisory councils, whereas the constitutions of Baden-Württemberg, Bavaria, Lower Saxony and Mecklenburg-Western Pomerania do not have any specific regulations (Gesemann and Roth 2014). In addition, some federal states 
have enacted 'Integration' or 'Participation' laws, which enshrine a number of binding regulations on the representation of migrants (Expert Council of German Foundations 2017).

Unsurprisingly, states such as NRW and Hesse, which have a long tradition and strong regulatory framework, tend to have larger numbers of migrant consultative bodies, compared to states like Bavaria in which such measures are lacking (Dietz, Eißel and Naumann 2013). A study on local integration policies (Gesemann, Roth and Aumüller 2012) revealed that 64.2 per cent of municipalities have an institutionalized form of migrant representation, and major cities are particularly active in promoting such bodies. The composition, appointment of members and main statutes of migrant advisory committees vary according to the different regulations in their constitutions. In some cases, representatives are elected by the non-German population, while in others members are selected by the municipal council. Often, integration councils tend to have an advisory function, and therefore can only advocate for the interests of immigrant populations but not make binding decisions. Furthermore, it has been highlighted that next to the lack of decision-making power, the scarce financial resources of many integration councils limit their capacity to exert influence at the communal level (Hunger and Candan 2009). In addition, the low turnout in many council elections, which is on average around 10 per cent, poses a challenge to the legitimacy of migrant representative bodies (Vicente 2011).

For example, the Director of the Cologne Integration Council interviewed for this research told how it pursues its objectives to promote equality of opportunity for migrants to participate in urban society and to highlight the migrant perspective on issues of concern at the city level. The council is made up of twothirds directly elected migrant representatives and one-third council members nominated by the political parties represented on the city council. Every person who has permanent residence status in Germany and has been registered in Cologne for at least three months can stand for election and is eligible to vote for a migrant representative. Given the temporary nature of their legal status in Germany, people in the asylum process or with refugee status are not allowed to run for or participate in the elections to the integration council. In light of this, efforts have been made by the council to reach out to the refugee population in Cologne and to create contacts with refugee organizations in order to safeguard their interests and ensure that their needs are being addressed by the municipality (Ragab 2018: 12). 


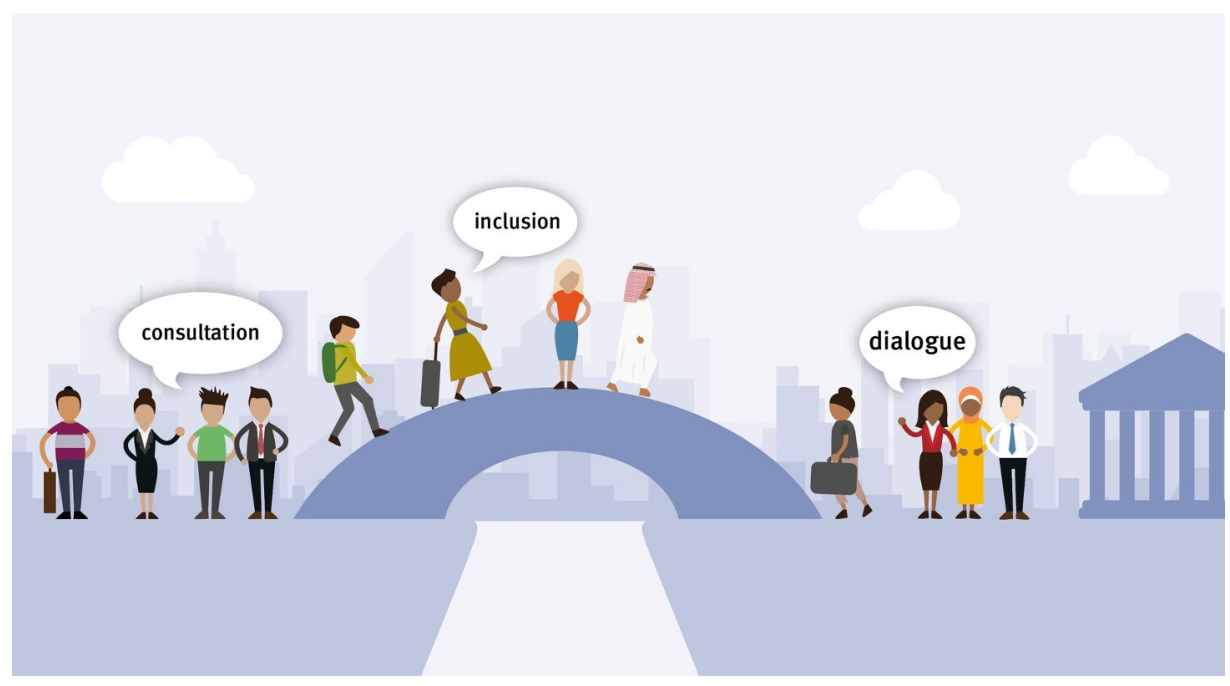

Figure 3. Consultative bodies

The interviews with Afghan and Syrian refugees in Germany revealed that engaging in consultative bodies, such as migrant advisory committees (Ausländerbeiräte) and integration or migration councils, is seen as a way to ensure their political representation at the local and regional levels. For instance, one Afghan respondent was a member of a city district migration council in Berlin, which comprises representatives of migrant organizations, local politicians, the police and staff members of the Federal Office for Migration and Refugees, as well as NGO representatives. Representatives of migrant organizations are not directly elected but have to apply for a position at the local integration office. The work of the migration council addresses the various aspects and challenges of migration and integration at the district level, ranging from the provision of integration courses to long-term programmes of anti-racism work. In addition, the respondent had recently been elected to the Council for Integration and Migration Questions in the state of Berlin (Landesbeirat für Integrations- und Migrationsfragen). This body makes recommendations on the further development of integration policy at the state level. Given the advisory function of these councils, their influence and capacity to shape migration and integration policies very much depend on the willingness and openness of the local and regional governments. According to the respondent: 'Of course, they also promise us a lot with the new government. On the one hand certain people were responsible for the fact that it [the council] was established in the first place. They take our suggestions very seriously, so we expect a lot from it' (Ragab 2018: 17). 
Consultative bodies are not the exclusive prerogative of European countries but exist in one form or another in the Middle East and North Africa region and in sub-Saharan Africa. The case of Refugee Welfare Committees (RWCs) introduced in Uganda as an alternative mechanism for political participation is an illustrative example. RWCs are made up of directly elected representatives in refugee settlements. Refugees elect leaders to serve as liaisons between the Office of the Prime Minister (OPM), service delivery partners and refugee communities. RWC structures are a non-political mirror of the local council system and are positioned to complement the work of the OPM. They are not established by law, however, and confine refugees to settlement-specific issues, such as ensuring that food rations are distributed properly and mediating household or community-based conflicts as they arise. Although this system has proved an effective way for settlement authorities to maintain communication with refugees, it is not a method of governance that is initiated or driven by refugees themselves. In the five refugee settlements sampled for this research, refugee leaders raised the restrictive nature of their role and the inability to participate as stakeholders in the decision-making processes relevant to them. As a Congolese refugee leader noted:

The first thing we were told when we arrived here was no involvement in politics in either Congo or Uganda ... [The] RWC system is effective but RWCs cannot make a decision OPM doesn't want. [RWC] candidates must be approved by the OPM, sometimes [elections] are transparent, but sometimes not.

—Congolese RWC refugee leader 1, Nakivale, 2017 (Zakaryan 2018: 14)

A member of a Congolese student association in Kampala stated that refugee leaders are not able to be fully autonomous in their roles and can be easily influenced by the settlement authorities, given the poverty and internal corruption that characterize refugee settlements. Throughout the course of this research, Congolese and South Sudanese leaders commonly described their roles as symbolic rather than operational. According to South Sudanese RWC leaders in Nyumanzi, 'Advocating for refugee issues is not easy... we receive no feedback yet leaders are called the "voice of the community" - it is useless ... no one consults refugees on service delivery and food reduction' (Zakaryan 2018: 14).

Despite the limitations of the RWCs, they have led to positive developments in expanding leadership roles for men and women. For instance, the Nyumanzi Refugee Settlement hosts South Sudanese refugees who arrived in Uganda in 2013. In 2017 women began serving in RWC leadership positions largely as a result of lobbying by OPM officials. One female refugee leader reflected on the 
cultural aspects that initially limited her involvement and on her current opportunities as a leader:

I was a leader in my village [in South Sudan] only because women were many and men were few. According to Dinka culture, women cannot be elected to village level leadership and they cannot speak in the presence of men. Now we, as refugee leaders, are the link between the issues on the ground and the OPM and UNHCR, but we do not have further political participation.

—South Sudanese refugee leader 1, Nyumanzi, 2017 (Zakaryan 2018: 14)

Along the same lines, when asked to identify and elaborate on ways that refugees could have a larger say in host country policymaking, Syrian respondents in Turkey expressed the need for consultative bodies that would represent Syrian refugees at the national and municipal levels:

We need some kind of committee or representative body in countries where there are a large number of refugees. Such committees would regularly visit the refugee camps and places where there is a concentration of people. They would then be in contact with the government and advocate for refugees' interests.

—Syrian female refugee 1, fashion designer, Gaziantep, 2017 (Mannix 2018: 14)

Therefore, although the roles and decision-making powers of consultative bodies are often rather limited, they do have an important-at least symbolicvalue in representing the wider refugee communities and developing positive refugee-host community relations. Consultative bodies can also serve as a unifying platform for refugees to advocate for the issues most prevalent in their communities and as a mechanism to facilitate refugees' participation in political life and enhance their sense of belonging in the society of their host country, despite their lack of formal electoral and citizenship rights.

\section{Participation in civil society organizations}

Participation in CSOs in their host countries can offer a degree of empowerment for refugees and a significant platform to make their voices heard. It can also serve as an important means of integration into the host society by providing opportunities to interact and to build bridges between the refugee population and local communities in pursuit of a common cause. In all the case studies 
conducted for this report, respondents discussed various examples of engagement with CSOs, either assuming a prominent role as founders or becoming involved as members.

In the case of Afghan refugees in the UK, engagement in CSOs and charities, as well as cultural and literary associations, offers common spaces where naturalized and non-naturalized refugees, as well as asylum seekers, take part on the same platform and advocate for a common cause, irrespective of their legal or citizenship status (Staniewicz 2015). Cultural and literary unions were particularly popular among refugee groups. Small and run by Afghans for Afghans, they present a unique opportunity for older and younger generations of Afghan refugees and asylum seekers to gather in one place. Some of these entities are not formally registered and keep a low profile by gathering for cultural, literary or political discussions. Other more regular groups, such as fundraising, advocacy and lobbying entities, are registered in England and Wales either as charities or as Community Interest Companies, which are social enterprises that use their profits and assets for the public good. If an entity's annual income is less than GBP 5,000, there is usually no need to register as a union or community group (Charity Commission 2014). These groups often advocate for refugees' rights and offer support to newly arrived refugees. Trade unions are also a useful platform where professional and skilled refugees can find help and support to further their professional interests (Staniewicz 2015). Some trade unions have more relaxed and open membership policies, and even accept asylum seekers. For example, the National Union of Journalists allows membership for UK-based asylum seekers who are prevented by law from working in the UK, and they are not required to pay subscription fees (National Union of Journalists 2017). Despite the favourable legal framework and openness of CSOs towards refugees, however, a notable challenge highlighted by many respondents was lack of funding. For example, a representative of the Paiwand Afghan Association in London, working on issues related to refugees and asylum seekers in the UK, told how while there is interest from public and private bodies in funding integration projects for refugees, such as social and cultural activities, public awareness projects aimed at improving civic and political participation by refugees and asylum seekers, which are equally crucial for integration into British society, are not backed by public and private donors and have not been officially recognized as an important aspect of integration (Sharifi 2018: 16).

In Sweden refugees also have the right to establish organizations and associations. According to the Swedish anti-discrimination law and the right to equality enshrined in the constitution, refugees' organizations are funded and supported by the state and local municipalities through the Swedish Agency for Youth and Civil Society (Myndigheten för ungdoms och civilsamhällesfrågor, MUCF). There are no legal restrictions on migrants or other minority groups joining or setting up CSOs (Mundzic 2015). The requirements for establishing 
an association or organization involve a few simple technical and legal steps, most notably registration of the new organization with the relevant institutions. Hence, many refugee groups have founded their own organizations on arrival in Sweden. Many of these local refugees' organizations participate in national networks or umbrella organizations of immigrants from the same country of origin or with the same cultural background. For example, the Group of Ethnic Associations in Sweden (Samarbetsorgan för etniska organisationer i Sverige, SIOS) is an umbrella organization for around 20 groups. The organization focuses on immigrants' native language and culture, equality and democracy, and as of 2014 had around 80,000 individual members (Bivald et al. 2014). Furthermore, a number of associations are well known and very active among the Syrian and Somali groups. The Syrian National Association in Sweden (Syrianska Riksförbundet) was founded in 1978 and as of 2015 had 12,653 members. The association's mission is to protect the Syrian minority's ethnic, cultural, linguistic and social interests (Mundzic 2015). Another example is the Somali National Association of Sweden (Somaliska Riksförbundet i Sverige), which aims to promote community development and political participation in both Sweden and Somalia (Somaliska Riksförbundet i Sverige 2017). Other organizations focus on social issues at the community level. As stated by one Somali female refugee in Stockholm: 'I am a member of a youth network targeting refugee youth between 17 and 25 years old. We organize events such as university days, discussion forums, graduation dinners and lectures in various locations' (Adan 2018: 15).

Refugees in Sweden have also established CSOs to advocate for political inclusion and provide capacity-building for young refugee leaders. An illustrative example is the Young Republic, a youth organization working to empower young Syrians and foster democratic participation, civic engagement and social inclusion in their host communities (Adan 2018). Another notable example is Järva Veckan, an annual forum that brings together Swedish political party leaders with representatives of migrant and refugee organizations, local authorities, private companies and citizens to discuss issues related to integration, diversity and inclusion. The initiative was started by a Somali refugee in 2016 and takes place in a suburb with a high concentration of migrants and refugees, with a view to reducing the gap between suburban residents and politicians, creating better conditions for migrants and refugees to engage in politics and putting their questions on the political agenda (Expressen 2017; Global Village 2017). Others, such as the Somali Association of Sweden, do not directly advocate for the political participation of refugees but instead cooperate with various stakeholders to promote the interests of the Somali community in Sweden. They also organize awareness-raising and training activities for newly arrived refugees to inform them at an early stage about their rights and obligations, increase their understanding of the host country and contribute to smoother integration. According to one member of the City Council in Malmö: 
The integration of refugees and their children plays a crucial role in the civic and political life of the host country. Obtaining a residence permit and citizenship allows the refugees the right to vote, take part in formal political life and be involved in all levels of the decisionmaking process in society. Many EU countries, including Sweden, are realizing that refugees have become important political stakeholders for both the host country and their country of origin. Sadly, many of them [refugees] are not aware of how significant their participation in the politics of the host country is.

—Somali City Council member, Malmö, 2017 (Adan 2018: 16)

At the same time, among the challenges highlighted by several participants in the Sweden case study was insufficient knowledge and information about the various mechanisms for non-formal participation in political life, as well as the lack of resources and contacts. They indicated that refugees who have obtained Swedish citizenship have a higher rate of participation, mostly attributable to their long residence and network of connections (Adan 2018). Refugee organizations and associations with a long history of political participation in Sweden have more experience and easier access to resourses and contacts than newly established ones (Mundzic 2015).

In the case of Germany, migrant organizations are actively supported with financial aid and capacity-building provided by the Federal Office for Migration and Refugees (Bundesamt für Migration und Flüchtlinge, BAMF 2016). Besides this federal initiative, there are several programmes at the state and local levels that aim to foster migrants' self-organization (Gesemann and Roth 2014; Gesemann et al. 2012). As an example at the regional level, the Ministry for Labour, Integration and Social Issues in the state of NRW provides capacity development and financial resources specifically tailored to the needs of migrant organizations (MAIS NRW 2017). In addition to state-led initiatives, several CSOs and political foundations promote civic and political participation by asylum seekers and refugees in Germany. For instance, Politische Partizipation mit und von Geflüchteten (Political participation with and for refugees), an initiative of the Heinrich Böll Foundation in NRW, seeks to develop concepts for political education in dialogue with the displaced population, as well as other local initiatives on refugee assistance. The workshops in this initiative found that in addition to dialogue, the training of volunteers and the empowerment of refugees should be central tasks of political education. Often, participants had already acquired broad knowledge of the political context not just of their countries of origin, but also of European societies. Hence, involving the target group in the design of political education services based on dialogue ensures that relevant needs can be addressed. At the same time, target group-specific challenges 
related to language limitations and experiences of displacement make work in this area more complex compared to conventional educational work. In particular, there is a need for qualified personnel trained to deal in a sensitive way with people who have experienced conflict and displacement. Additional resources will therefore be needed to empower the newcomers to become an equal part of society. According to the Director of the Heinrich Böll Foundation:

If we think long term, politically participating people are always

better for a democracy than a mass that is dissatisfied.

(Ragab 2018: 13)

In another example, the pilot project Teilhabe durch Engagement: Das Engagement von und mit Flüchtlingen stärken (Participation through engagement: Strengthen the engagement of and for refugees), implemented by the Bundesarbeitsgemeinschaft der Freiwilligenagenturen (BAGFA), aims to foster, encourage and support civic participation by refugees and asylum seekers in 10 cities across Germany. At the same time, the project aims to ease those newly arrived in Germany into voluntary engagement with the host society. It also supports CSOs, associations and initiatives in the host country to open themselves up to refugee engagement. The interim conclusions of the project show that there is a high degree of willingness to become engaged in the host community among the target group, and that many participants had already acquired experience of voluntary work in their country of origin. One of the success factors for reaching out to the target group was to create spaces for encounters in which both the newly arrived and local volunteers can share their experiences.

As highlighted by a BAGFA project manager interviewed for this case study, among the main challenges are the prejudices of some German CSOs, which tend to consider refugees as victims that are vulnerable, traumatized and problematic, rather than as active individuals with useful resources and skills that can contribute to the host society (Ragab 2018: 13). Another potential challenge is related to state funding of migrant organizations. Although state support for migrant organizations can address structural barriers to conventional funding, state-led funding schemes often tend to favour bigger umbrella organizations. In addition, preference is given to similar projects led by organizations already established in the host society, while newly established migrant organizations struggle to access such funding (Weiss 2013). Furthermore, many Afghan and Syrian respondents in Germany perceived that even if their voices were heard, they were seen as the voices of 'the refugees' and not of independent political actors. They were concerned about the portrayal of refugees in the mainstream media and the public discourse as either passive victims in need of assistance or a threat to European society, identity, culture and security. Knowledge of the host 
country's language was also identified as a crucial barrier not just to articulating political demands, but also to experiencing and understanding the local context and culture in order to be able to engage actively in non-formal political participation (Ragab 2018: 18-19).

In South Africa, there is no legislation or policy to restrict the formation of refugee associations or CSOs. On the contrary, legislation and structures have been put in place to support the establishment of such organizations. These range from faith- and community-based organizations to other developmental and social organizations. According to Statistics South Africa (2017), a non-profit organization must be a legal entity created by process of law. Among the different categories of non-profit organizations, refugee groups are likely to come under indigenous or territorial groups, which are organized around either cultural or ethnic groupings or a particular geographic area, mainly for the purpose of improving the welfare of their members (Statistics South Africa 2017). The 1996 Bill of Rights (Chapter 2 of the 1996 Constitution) discusses rights such as equality, freedom of expression and association, freedom of opinion and freedom to demonstrate, picket and petition. These are extended to all, including refugees.

A number of CSOs represent Congolese refugees and other categories of migrants in South Africa. Many of these allow membership and participation by citizens and non-citizens alike. In one way or another, a majority of the refugees interviewed either actively participate in or contribute to the activities of refugee associations, CSOs and grassroots initiatives. The objectives and activities of the various CSOs working in and for refugee communities vary but most organizations seem to offer direct assistance such as legal, medical and psychosocial support. Other organizations focus on civil and political issues and are mainly concerned with influencing people, outcomes and processes in the country of origin, using various strategies and tactics. In addition, organizations such as the Legal Resource Centre, the Adonis Musati Project, the Scalabrini Centre, the Consortium for Refugees and Migrants in South Africa (CoRMSA), Lawyers for Human Rights, Africans Unite and various law clinics offer legal advice and litigation services to vulnerable groups, including refugees and asylum seekers (Mpeiwa 2018: 18). The more politically inclined civil society groups are increasingly networking and lobbying South African political parties. They mainly target opposition parties and court the media on matters of potential mutual interest. Among the biggest challenges faced by refugees with regard to their civic and political participation in South Africa are the attitudes and actions of host communities, which are influenced by politicians, traditional leaders and other prominent figures. The sentiment that refugees and other migrants are being 'done a favour' by host communities and South Africans perpetuates the negative perception of migrants and elevates South African's sense of superiority at the expense of non-nationals. As a result, most foreign nationals, including 
refugees, feel unwelcome and threatened in their host communities (Mpeiwa 2018: 22).

Refugees in Uganda are allowed to engage in social associations and CSOs as long as they are not politically motivated. Article 29(g) of the Refugees Act of 2006 states that refugees 'have the right of association as regards to non-political and non-profit making associations and trade unions', but political activity at either the local or the national level is prohibited. Restrictions on political engagement in Uganda are also contained in article 35(d), according to which a recognized refugee 'shall not engage in any political activities within Uganda, whether at local or national level'. Refugees have the right to organize themselves in social, cultural and religious platforms and, to some extent, contribute to the governance processes of humanitarian service delivery. Furthermore, article 35(e) requires that a refugee must not 'undertake any political activities within Uganda against any country, including his or her country of origin'.

According to a Senior Protection Coordinator and international NGO representative working at the Elegu Reception Centre in Adjumani, the restrictions on refugees engaging in Ugandan politics or the political affairs of their country of origin are generally justified by the need to disengage from the 'bad politics' that led to their exile (Zakaryan 2018: 10). Many refugees interviewed for the Uganda case study immediately recalled being informed by the OPM that they were not permitted to engage in politics, but could participate in community-based associations specific to the challenges of, and development and economic initiatives in, their immediate surroundings. Most of the humanitarian and development organizations that support social and civic programmes gear their work to supporting refugees and host communities to create by-laws for guiding their coexistence or helping refugees to understand the Ugandan legal system in relation to the national and international laws mandating their protection.

The field research carried out in Uganda found that refugee-led organizations arise from the gaps that refugees experience in service delivery. While initially responding to the need to improve conditions in exile, these organizations evolved to address the prospect of repatriation. For example, one refugee-led organization that has the joint aims of promoting the interests of Uganda-based refugee communities and implementing programmes in the DRC was formed in Uganda's Kyangwali Refugee Settlement in the south-west of the country in 2005. Its dual objective is to respond to the lack of educational opportunities for DRC refugee youth in Uganda and to position those same youth to contribute positively to the development of the DRC on their return. An organization representative in Kampala discussed the programmes that have been developed and utilized in Uganda and are now being implemented in the DRC: 
We are organizing training on entrepreneurship so our youth can end their dependency on aid, sustain themselves and manage resources in a good way ... . [and] leadership training so they can serve their communities and not personal interests. ... [Young people are] encouraged to develop both as a community and as individuals.

-Congolese male refugee and NGO representative 1, Kampala, 2017 (Zakaryan 2018: 16)

In Turkey, there is some space for the direct engagement of refugees in CSOs. In order to form a dernek (non-profit association) in Turkey, an interested party must apply to the Turkish Interior Ministry Bureau of Associations (Dernekler Dairesi Başkanlı̆̆l) (Turkish Interior Ministry Bureau of Associations n.d.). The organization must have seven founding members, who should be Turkish citizens or foreigners with proof of permission to settle in Turkey, such as a residence or work permit (Turkish Interior Ministry Bureau of Associations n.d.). A dernek also requires 17 board members, who can be foreign nationals. The board can comprise the seven founding members and 10 additional members or 17 different citizens or resident non-citizens. As of June 2017 there was one community centre NGO founded by a non-Syrian foreign national working with refugees in Istanbul. It was in the process of applying to become a dernek and planned to have one Syrian with temporary protection on its board, subject to government approval. While the NGO founder had faced inquiries from the government regarding the number of foreigners on the board, she had been told that there was no limit to the number of foreign nationals with a residency permit who could serve on it (Mannix 2018: 11).

For their part, Syrian-led or Syrian-focused CSOs and NGOs based in Turkey mainly focus on closing the gaps left by government provision of essential, shortterm services rather than on long-term rights such as civic and political participation. The NGO Citizens for Syria lists 67 NGOs that have headquarters or offices in Turkey and work in the areas of health, development, politics, emergency relief and the media. In addition, there are many more organizations in Turkey with varying capacities, missions and scopes. These include for-profit 'consulting' firms based in Gaziantep that are run by and employ Syrians in Turkey to carry out monitoring and evaluation services or cross-border capacitybuilding projects (Citizens for Syria n.d.). In addition, smaller CSOs in Turkey often provide activities and vocational training to urban Syrians in Istanbul (Small Projects Istanbul, Ad.dar, Yusra Community Center, Pages Bookstore) and Gaziantep (Kurkayak). These often double as cultural and education centres. For example, Pages Bookstore in Istanbul sells Arabic language books and organizes live music performances and plays, Ad.dar offers Turkish and English lessons, and Small Projects Istanbul offers skills development programmes specifically for 
Syrian women by teaching them handicrafts. Another example is Refugee Rights Turkey, which provides free legal assistance to Syrian refugees, with a view to mitigating the challenges linked to refugees' access to justice. Overall, the organizations with the greatest capacity and freedom to operate inside Turkey are those that assist with the immediate and humanitarian needs of Syrians. Meanwhile many organizations lack capacity, such as human resources, organizational structures and staffing (Mannix 2018: 15-16).

On the other hand, the examples of Kenya and Lebanon present a more difficult reality for refugees' participation in CSOs. The legal, regulatory and financial frameworks for NGOs in Lebanon do not specifically mention whether a refugee can establish a CSO. However, legislative decision no. 369 of 1939 stipulates that foreigners have the right to form an association by virtue of a special decree issued by the Council of Ministers (Ministry of Social Affairs, Lebanon 2004). In practice, this has proved to be a very difficult procedure, as various councils of ministers have adopted a conservative attitude to granting formal recognition for foreign NGOs in Lebanon, especially Syrian ones. Hence, Syrian refugees mainly convene in informal groups that are not officially registered or resort to Lebanese covers to register their organizations, exactly as Palestinian refugees have consistently done since they settled in Lebanon. Some of the Syrian participants in the Lebanon case study were active in CSOs in Lebanon, mainly in the fields of emergency response and development. Despite the restrictions that non-Lebanese citizens face on registering NGOs, the Lebanese government 'takes a laissez faire approach to NGO regulation and foreign NGOs can work informally in Lebanon without disturbance, unless they engage in "suspicious activities"' (Elbayar 2005). The interviews showed that, despite the specific administrative challenges, there are many windows of opportunity for participation by Syrian refugees in civil society activities in Lebanon. A Syrian male refugee and political activist in Beirut explained:

In 2013, our group of volunteers became an NGO. We are five founders, four Lebanese and one Syrian. Although this is not against the law, the establishment of the organization took a lot of time, because one of the founders was Syrian. The Lebanese authorities used the pretext of the US sanctions against Syrians. Even banks did not want to open accounts for us, but then it worked using connections.

—Syrian male refugee and political activist 1, Beirut, 2017 (El-Helou 2018: 14)

In the same vein, a female refugee and political activist stated that after futile efforts to register an NGO in Lebanon, she gave up and decided to register the 
same NGO in the Netherlands, which continued to operate under cover in Lebanon (El-Helou 2018). 'Touch of a Rose' constitutes another example of a CSO working with Syrians in Lebanon. It is led by Syrian refugees and implements training activities aimed at introducing young Syrians and Lebanese to the concepts of civic education, critical thinking and the principles of democracy (European Endowment for Democracy 2017). Furthermore, the Syrian Centre for Political and Strategic Studies publishes studies on Syria-related socio-economic and political issues. Its mission revolves around educating citizens and activists about Syria's 'political, economic, social, and strategic perspectives', through different types of conferences, publications and studies. The centre also translates major books and research papers on Syria in the fields of economics, political and social science, and cultural studies (Syrian Centre for Political and Strategic Studies n.d.). The Syrian League for Citizenship is an example of Syrian-led civil society activity focused on issues of political participation. It was founded by a Syrian female refugee and political activist in Beirut, who was one of the respondents to the Lebanon case study:

We work on building the capacity and raising the awareness of Syrian youth on issues related to citizenship and rights, through established contacts inside Syria whereby awareness raising sessions and capacity development workshops are conducted. The Syrian League for Citizenship is a gathering of people focusing on the values linked to the relationship between the citizen and the government and among citizens themselves. The mission is related to the idea of citizenship and the democratic state that is founded on four principles: freedom, participation, equality and responsibility, where both men and women have their rights and duties fulfilled without any form of discrimination.

—Syrian female refugee and political activist 1, Beirut, 2017 (El-Helou 2018: 15)

Another example is Basmeh and Zeitooneh, an organization that started working for the benefit of Syrian refugees in 2012. It began by undertaking field visits in areas where the most marginalized and vulnerable Syrian refugees and asylum seekers lived. The main goal of these visits was to assess needs and identify gaps left by other aid agencies. The purpose is also to support and empower the refugees, in addition to building their sense of belonging to the host society through the establishment of community centres in different regions across the country and the formation of partnerships with local stakeholders (El-Helou 2018: 15). 
Lastly, in the case of Kenya, the possession of a Kenyan ID card is a key legal requirement when forming any organization, including non-profit organizations and NGOs. As a result, refugees are not allowed to formally establish their own CSOs unless they have obtained Kenyan citizenship. One of the few avenues left for political participation is informal engagement with civil society or advocacy groups run by others and the conduct of informal participatory processes in the refugee camps. For instance, periodic elections of camp leaders at the block, zone and camp levels are held in Kakuma camp every three years. The Kenyan Department of Refugee Affairs functions as the 'electoral management body' that oversees the elections, while the Jesuit Refugee Service provides returning officers and logistical support. The elections are hotly contested, campaigning is allowed within the camp and forums are held to discuss candidates' plans to improve the welfare and living conditions of refugees. In addition, by-elections are held when leaders are resettled to other host countries. Although the focus group participants in Kakuma acknowledged that they had participated in these elections, the fact that they were exclusively for refugees led them to perceive them as 'less serious'. Their attitude was reinforced by the fact that in reality, political power and decision-making remained in the host community. Participants in the Kenyan case study argued that such elections should involve the host community, and that issues such as legal status, camp conditions, and the movement and security of refugees should be part of the campaign agenda (Opon 2018: 13-14).

As the cases examined above show, in all the host countries except Kenya there are no significant legal barriers preventing refugees from founding or becoming members of CSOs. Despite the various practical challenges outlined above, a plethora of refugee-led or refugee-focused CSOs have emerged that provide important avenues for refugees to engage in the civic and political life of their host countries, make their voices heard, strengthen the links with the native-born population and feel part of the host society.

\section{Protests and grassroots initiatives}

Another mechanism for non-formal political participation by refugees in their host country is through protests and grassroots initiatives, two means of mobilization that essentially depend on the host country's commitment to guaranteeing the exercise of the fundamental rights of association and protest. These activities can be exercised regardless of legal status as refugees, asylum seekers or citizens, and often provide meaningful ways to express the challenges faced by communities in making their voices heard.

In the case of Sweden, protests are mostly linked to resistance to changes in Swedish refugee and asylum policy or other issues affecting refugees at the community level. For instance, in 2016 refugees united their voices with grassroots initiatives to protest in Stockholm and 14 other cities against forced 
deportations and the abolition of permanent residence permits for refugees (Mortimer 2016). Other examples include the organization of protests against restrictions on the naturalization of Somali refugees, who have to wait three years more than other refugees to be eligible for naturalization (Adan 2018: 17).

For Afghan and Syrian respondents in Germany, there was a palpable need to participate in political movements in their host country, given their exclusion from electoral rights. The more recent refugee-led grassroots initiatives tend to be more enduring, and their actors nationally and internationally connected (Klotz 2016; Schröder 2016). For example, a migrant- and refugee-led grassroots movement has emerged in light of the current political debate and policy environment in Germany, which considers that there are safe areas in Afghanistan to which rejected asylum seekers can be returned. According to Afghan respondents who were involved in this initiative, it aims to mobilize solidarity against deportations in wider German society and to advocate for equal opportunities in the integration process. As part of this initiative, the Forum for Afghan Migrants was established in Cologne by Afghan asylum seekers in 2016 to enable all Afghan people to participate in integration and language courses, to fight against deportations from Cologne to Afghanistan and to counter racism, discrimination and xenophobia. The activities of the forum range from practical assistance with government agencies and doctors' visits and the organization of information events on asylum procedures, to organizing political campaigns and protests.

Another example is the protest camp organized by asylum seekers in front of the BAMF building in Dortmund in 2015. Around 100 asylum seekers protested for 54 days, demanding the repeal of the Dublin Regulation-which defines the obligations of states in evaluating the asylum claims presented by people who arrive in Europe (European Parliament and European Council 2013) - as well as faster processing of asylum applications, facilitated conditions for family reunification, German language courses for all asylum seekers and facilitated access to work and higher education for asylum seekers. According to a Syrian respondent who was one of the organizers of the camp, the initiative was an important way to put pressure on local authorities to improve the living conditions of asylum seekers and to raise awareness among the wider German public. Furthermore, according to some Syrian respondents, their political activism aims to challenge the discourse of pity that they feel is present in the current debate about refugees, as well as the perceived restrictiveness of European asylum policies, by highlighting the complexity and diversity of refugees' experiences. They also seek to connect the political struggle for human rights, and against the marginalization of and discrimination against refugees, with the geopolitical root causes of forced displacement, by providing information about the embeddedness of the Syrian conflict in broader geopolitical power struggles. In this respect, a male Syrian activist in Berlin stated: 
Our work could maybe provide input for people to change the narrative on refugees. Many people see refugees as people who popped up in the Mediterranean. For many people, the story begins only in the Mediterranean in boats. [...] We don't need to focus on what refugees are doing but what Syrians or Afghans are doing. We started to dismantle the term refugee itself.

—Syrian male respondent 1, Berlin, 2017 (Ragab 2018: 18)

In addition, the arts and culture provide some respondents with an alternative space for political expression. For example, one Syrian respondent frequently organized art exhibitions and literature festivals to provide an opportunity for Syrian artists and writers in exile to present their work to a broader audience. These events give artists the creative space to explore and express their identities, but also enable them to challenge discrimination and foster intercultural dialogue. Through their work, the artists often illustrate their troubling story of expulsion, flight and exile as well as their struggles for freedom, democracy and a better life in Syria. Notably, many respondents acknowledged and valued the freedom and space for political activism available in Germany as their host country. According to one female Syrian activist in Berlin:

You cannot feel that you are really integrated or that you are powerful unless you are involved in the local things happening here [...]. Being engaged here in Germany is very important because here are the tools, the freedoms to express yourself and freedom of belief in general. This is an opportunity. I believe that being socially and politically active is very important. That was one of the main reasons for the revolution in Syria, and why I joined it.

—Syrian female respondent 1, Berlin, 2017 (Ragab 2018: 14)

As in Sweden and Germany, several Afghan respondents interviewed in the UK noted that their host country offers opportunities for many lobby groups and rights activists to organize protests in which everyone, even asylum seekers, can participate. The types of demonstrations Afghan refugees usually take part in are either pro-refugee rights or to denounce certain countries' involvement in Afghanistan. A former Afghan government minister, now a refugee in London, argued that: 'Britain is the best place to draw attention to and create international pressure on the countries involved in Afghanistan's conflict, such as Iran and Pakistan' (Sharifi 2018: 15).

Most of these demonstrations take place in London, and it seems that protest is more a practice of choice for asylum seekers than for refugees with recognized 
status. Those interviewees with British citizenship appeared to be the least interested in taking part in protests. They claimed to be too busy and that protests initiated by Afghan refugees were 'too disorganized' and often suffered from a very low turnout. In addition, for some Afghan refugees taking part in demonstrations is a big commitment. One Afghan respondent with refugee status said that attending demonstrations entailed travel costs and giving up at least one day's income. Apart from the financial constraints, there were other reasons that made attending protests a difficult choice for some refugees and asylum seekers. As a male refugee activist in Manchester explained:

Refugees and asylum seekers fear they might be arrested or the demonstration may get out of control and their presence on a demonstration could affect the Home Office decision on their asylum application. They have inherited this fear from back home. . . We organized a Refugees Welcome March and tens of thousands of people participated, but only 25 per cent of the attendees were refugees.

—Afghan male refugee 3, activist, Manchester, 2017 (Sharifi 2018: 15)

Similar concerns were raised by refugees in Kenya, Lebanon, South Africa, Turkey and Uganda, who expressed fears that their participation in protests would result in them being perceived as a 'security threat' and having their refugee status revoked by their host countries.

In South Africa, the Bill of Rights and the Regulation of Gatherings Act (1993) afford everyone the right to assemble, demonstrate and picket, as long as they are unarmed and do so peacefully. One requirement is to notify the local council, which in turn must notify the local police, of the planned protest at least seven days before it is due to take place. Although this notification is not about seeking permission to exercise the right to protest, the authorities have several grounds on which they can prohibit the protest, such as possible harm to other people or their property. A representative of an intergovernmental organization in Pretoria interviewed for this research alleged that he was prohibited from staging a protest against xenophobia in Pretoria while the 'concerned residents of Mamelodi and Atteridgeville' were allowed to proceed with their anti-foreigner protest within the same time frame (Mpeiwa 2018: 19).

Notwithstanding the above, based on the interview responses, for most refugees and asylum seekers the organization of or participation in protests and marches is mainly undertaken by the more politically active individuals and civil society groups, even though there have been instances where 'apolitical' refugees and asylum seekers have joined organized protests, usually around issues that directly affect them. However, given their uncertain and temporary legal status, they felt 
reluctant to express their frustrations on any matter in a way that might attract negative attention from the authorities or adversely affect their applications to renew or extend their residence permits (Mpeiwa 2018: 19).

In Kenya, too, the consensus among the participants in a focus group in Nairobi was that participation in politics through the formation of advocacy groups and grassroots initiatives would risk undermining their refugee status. Having embarked on an unknown journey forced by conflict in their countries of origin, many respondents argued that they did not see any value in seeking change in a foreign country: 'We ran away from conflict started by politics in Somalia: why start another conflict here through politics?' (Opon 2018: 13). Somali participants in Nairobi were particularly averse to visibly engaging in any form of political activity that would make them stand out. This was mainly due to fear that any involvement in Kenyan politics might provide a reason to be targeted by the Kenyan security authorities for repatriation to Somalia. In addition, one-to-one interviews with South Sudanese participants revealed a sense of unease about any form of political activism in Kenya. A leading official in the Department of Refugee Affairs at the Kakuma refugee camp indicated that the Government of Kenya strongly discourages any form of political activism or mobilization in Kakuma due to the strong ethnic identities that inform the conflict in South Sudan (Opon 2018: 13).

In a similar way, a Senior Legal Protection Officer and International NGO representative in Bidi Bidi, Uganda described how: 'Refugees are reminded that they fled their origin countries because of safety issues and politics. They can put themselves together through church, dance and culture, and peaceful gatherings, but not through politics and demonstrations' (Zakaryan 2018: 16).

In countries such as Turkey and Lebanon, the vast majority of participants stated that they had not openly participated in any protests or similar public expressions of political belief, generally citing the riskiness of such involvement due to their temporary protection status. In Turkey, a notable exception was the 15 July 2016 coup attempt, when scores of Syrians took to the streets to protest against the coup for fear that military rule might lead to a crackdown and perhaps repatriation, citing how the coup in Egypt had led to the harassment of refugees by coup supporters (Porter 2016).

In Lebanon, one Syrian respondent affirmed that he had been active in the 'You Stink' movement in the summer of 2015. This movement was an informal platform formed by a group of activists in reaction to refuse piling up in the streets of Beirut in July 2015. It gained in popularity and attracted a lot of activists from all over Lebanon (Zogby 2015). A female refugee and political activist in Beirut indicated that she had participated in protests related to the right to Lebanese nationality: 'I was part of the protests related to giving Lebanese citizenship to the children of Lebanese women married to foreigners' (El-Helou 2018: 10). However, the Syrians interviewed in Lebanon generally considered 
that they did not 'have the right' to participate in protests over Lebanese issues. A male refugee and political activist in Beirut said: 'We might compromise the whole movement if we participate in protests, so it is better to stand aside' (ElHelou 2018: 13).

There was also a concern that vocalizing their political point of view might be perceived as running counter to the host country's political interests in the region. For example, in 2017 the Lebanese Armed Forces carried out a major raid in Aarsal, a border town in the Bekaa valley, which had been occupied by ISIS and the Nusra Front since 2014 (Al Jazeera 2017b). This resulted in a large number of arrests (Human Rights Watch 2017). An outcry followed, mainly from human rights activists and left wing groups, which eventually called a demonstration in support of refugees. A Facebook page under the name of the Union of Syrian People in Lebanon reposted the invitation and broadcast messages (videos and social media posts) from refugees vilifying the Lebanese Army. A number of Lebanese citizens reacted angrily in response, calling for counter demonstrations in support of the army which was being attacked by Syrians. This resulted in a vigorous public debate that could easily have escalated, until the Lebanese Ministry of the Interior decided to prohibit both demonstrations and arrest the administrators of the Facebook page (McLoughlin 2017). This incident indicates that any form of vocal political participation by Syrian refugees in Lebanon is not seen favourably.

Ultimately, the resilience of democratic norms and respect by host countries of the rights to freedom of peaceful assembly and association are necessary preconditions for refugees to be able to participate fully in the political life of their host countries through creating or joining CSOs, defending their collective interests and participating in lawful and peaceful protests. However, whether their claims will then be translated into policy reforms by the host country authorities is a matter for debate (Ataç, Rygiel and Stierl 2016). 


\section{Part II. Political Participation of Refugees in their Countries of Origin}

The engagement of refugees in political activities related to their countries of origin has the potential to affect democracy-building efforts back home. A diaspora can mobilize to raise awareness and advocate for democratic reforms in its country of origin, participate in post-conflict elections as voters, candidates or supporters of political parties, form governments-in-exile and political movements, and establish CSOs and transnational networks (Betts and Jones 2016; Ragab 2013). At the same time, diasporas have also been known to act as spoilers of peace processes in their countries of origin, particularly in periods of great political transition. Their political activities, either formal or non-formal, may at times have an adverse effect on peace and democracy in their countries of origin (Smith and Stares 2007).

That said, there is a strong case to be made for the inclusion of refugees in the political life of their countries of origin. The political participation of refugees in country-of-origin politics has a real and substantive value in terms of reconstruction-related activities. By facilitating refugees' engagement in postconflict political processes, these groups are more likely to see themselves as stakeholders in the peacebuilding and democracy-building processes. This in turn is likely to lead to more sustainable repatriation and return, as refugees are recognized-and recognize themselves—as equal citizens in their country of origin (Long 2010). This may also be understood as a way to enhance the legitimacy of any post-conflict political arrangement and contribute to the consolidation of democratic systems that aim to be all-encompassing, despite varying political viewpoints that may come from home or abroad. Exercising this 
right to vote and participate in the public affairs of the country of origin, however, depends in practice on the recognition of such a right by the country in question, and assumes a regime's commitment to core democratic values.

There are no specific requirements in the 1951 Refugee Convention regarding refugees' political participation in their countries of origin. However, the political inclusion of refugees is seen as a crucial component of international approaches to durable solutions. In this regard, the Zero Draft of the Global Compact on Safe Orderly and Regular Migration (Objective 19 (g)) calls for states to 'enable political participation and engagement of migrants in their countries of origin, including in peace and reconciliation processes, in elections and political reforms, by establishing voting registries for citizens abroad, and by parliamentary representation' (UN 2018). Furthermore, the Global Compact on Refugees (2018) recognizes the importance of reconciliation and confidence-building measures to prevent countries of origin from relapsing into conflict by 'facilitating the participation of refugees and returnees (notably women and youth) in relevant processes and decision-making, including peacebuilding activities' (UNHCR 2018). 


\section{Formal political participation of refugees in their countries of origin}

Refugees are by definition forced to leave their country of origin due to persecution, war or violence. The absence of choice and inability to return represent a constitutive element of, and a necessary condition for, their refugee status under the 1951 Refugee Convention. Accordingly, their normative claim to be included in the political life of a country that directly threatened or failed to guarantee their fundamental rights is arguably stronger than other categories of migrants who voluntarily emigrate and retain the possibility of returning. Yet, in practice, refugees face far greater obstacles to casting a ballot in country-of-origin elections. This is partly because exile may effectively exclude refugees, symbolically and physically, from participation in the political life of their country of origin (Ziegler 2017). Even when they are formally entitled to vote from abroad in elections of their country of origin, they have reasons to be reluctant to register with the authorities of a persecutory or unprotective country. In addition, their participation in post-conflict elections may be interpreted by their host country as an indication that they have re-availed themselves of the protection of their country of origin and that their refugee status therefore ought to be revoked, jeopardizing their right to stay and prompting their repatriation.

This chapter provides a comparative overview of the opportunities and challenges related to the participation of refugees from Afghanistan, the DRC, Somalia, South Sudan and Syria in the political life of their countries of origin through formal mechanisms, most notably out-of-country voting and standing as candidates. 
Table 5. Out-of-country voting and electoral rights in countries of origin

\begin{tabular}{|l|l|l|}
$\begin{array}{l}\text { Country of } \\
\text { origin }\end{array}$ & Out-of-country voting allowed & Dual citizenship for candidates \\
\hline Afghanistan & $\begin{array}{l}\text { Refugees have the right to participate in } \\
\text { elections, if possible, in separate polling } \\
\text { centres established by the Independent } \\
\text { Elections Commission. }\end{array}$ & $\begin{array}{l}\text { Candidates with dual citizenship can run } \\
\text { for parliamentary and local council } \\
\text { elections, but not for presidential } \\
\text { elections. }\end{array}$ \\
\hline $\begin{array}{l}\text { Democratic } \\
\text { Republic of the }\end{array}$ & N/A & $\begin{array}{l}\text { There is no prohibition on dual } \\
\text { citizenship for candidates running for } \\
\text { parliamentary and presidential elections. }\end{array}$ \\
\hline $\begin{array}{l}\text { Somalia } \\
\text { South Sudan }\end{array}$ & N/A & $\begin{array}{l}\text { There is no prohibition on dual } \\
\text { citizenship for candidates running for } \\
\text { parliamentary and presidential elections. }\end{array}$ \\
\hline Syria & $\begin{array}{l}\text { Citizens residing outside the country can vote } \\
\text { in embassies, provided that they have exited } \\
\text { the country 'legally'. }\end{array}$ & $\begin{array}{l}\text { Dual citizenship is not allowed for } \\
\text { presidential candidates. }\end{array}$ \\
\hline
\end{tabular}

\section{Electoral rights and out-of-country voting}

Enfranchisement of citizens abroad has essentially been confined to national elections_-presidential or parliamentary_or to referendums, whereas, as noted in Part I of this report, enfranchisement of resident non-citizens occurs mostly at the local level (Arrighi and Bauböck 2017). In the space of a few decades, OCV went from being considered a democratic anomaly that was difficult to reconcile with the requirements of territorial sovereignty to a democratic norm derived from the principle of popular sovereignty (Collyer 2014). The expansion of OCV is a truly global phenomenon, spanning sub-Saharan Africa (Hartmann 2015), the Middle East and North Africa region (Brand 2014) and the Americas (Escobar 2017). According to International IDEA's Voting from Abroad Database, 146 countries have enacted legislation allowing their citizens to vote from abroad.

Of the five countries of origin examined in this report, only Syria and Afghanistan have OCV regulations (see Table 5). There are no provisions for OCV in the DRC, Somalia and South Sudan. Insofar as OCV applies to all nonresident citizens irrespective of the circumstances that have led them to move abroad and of their legal status in their host country, in principle it also applies to refugees who continue to retain the citizenship of their country of origin.

Democratic transitions often provide a window of opportunity for extending suffrage to non-resident citizens (Rhodes and Harutyunyan 2010). Political elites in countries of origin that are undergoing regime change and democratic 
transition are often eager to enfranchise their populations abroad. First, they may use OCV to 'showcase' the organization of free and fair elections internationally in an effort to signal their commitment to democracy (Escobar 2017). Second, autocratic regimes often generate the creation of opposition parties, if not entire governments, in exile. On return to their homeland, parties or political figures that were once in opposition may push to enfranchise an external electorate perceived as a significant reservoir of voters who could easily be mobilized through existing networks forged over more or less extensive periods in exile. In the aftermath of regime change, the extension of suffrage is therefore often framed as a remedial right granted to a population that was forced out of the country in order to reintegrate them into a reimagined national community. For example, the fall of autocratic regimes in the wake of uprisings saw the inclusion of citizens abroad in multiparty elections in Tunisia and Egypt.

Furthermore, in the case of Afghanistan, the Independent Elections Commission considered OCV in the historic first democratic elections in 2004 for the nearly 3 million refugees living in neighbouring Pakistan and for the up to 1 million refugees hosted by Iran. Despite the lack of funds, bureaucratic and political obstacles in negotiations with the host countries and the limited time frame for preparing the logistics of the election, the enfranchisement of Afghan refugees in neighbouring countries can be regarded as a success, as they made up 10 per cent of the total 2004 electorate. At the same time, however, some critical voices argued that voting from Iran and Pakistan became highly politicized, since host countries tried to influence voting along ethnic lines to protect their political interests in the Afghan context (Slavu 2007, 2012).

Notwithstanding these claims, OCV in the 2004 Afghan elections seems to have been the exception rather than the rule, given that no arrangement was made for refugees abroad to cast their vote remotely during the subsequent 2009 and 2014 presidential elections (Shams and Khan 2014). To enfranchise Afghans around the world, the organization Afghan Peacemaker initiated an online petition to call for external voting rights for Afghans in the presidential elections of 2014. According to a member of the organization interviewed for the Germany case study, they successfully lobbied for the support of the Independent Election Commission (IEC) of Afghanistan, which saw OCV as an important measure for enfranchising the Afghan diaspora. Nonetheless, in light of tensions linked to accusations of manipulation and electoral fraud, OCV could not be achieved at that stage of the democratic process. Moreover, another Afghan respondent interviewed in Germany who had previously been working for the IEC emphasized the considerable logistical efforts as well as the potential for political interference by neighbouring host countries as the major challenges surrounding OCV for refugees (Ragab 2018: 23). Article 5 (5) of the 2016 Election Law states that refugees 'have the right to participate in elections, if possible, in separate polling centers established by the Commission'. However, as of March 2018, no 
arrangements had been made for OCV by refugees in the parliamentary elections scheduled for 2018.

Indeed, the numerous practical difficulties surrounding the organization of free and fair elections beyond the territorial jurisdiction of the country of origin tend to be aggravated by having to deal with the consequences of protracted refugee movements. Guaranteeing the integrity of a transitional election is essential if political actors, voters and the international community are to accept the outcome as legitimate. The successful implementation of OCV also requires that the country of origin's electoral management body has the necessary resources and capacities to supervise the conduct of free and fair elections abroad. The process requires the mobilization of considerable resources, which must be deployed not just for the short period preceding an electoral process, but on a permanent basis (Lafleur 2013). The corresponding electoral rolls must be updated on an ongoing basis, through administrative routines involving multiple agents and bodies, which carry the immense responsibility of ensuring that all refugees eligible to vote are properly registered, but none of those ineligible are. Once registered, refugee voters must be given appropriate access to the ballot through a voting method that must be sufficiently convenient not to impede the exercise of their voting rights, while at the same time providing the maximum guarantees against potential fraud or security concerns. The profound differences between the domestic and international arenas severely complicate the country of origin's capacity to implement OCV (Hutcheson and Arrighi 2015). These concerns can at least partly be addressed by delegating the technical implementation of OCV to specialized international or regional organizations, such as the International Organization for Migration (IOM), the UNHCR or the Organization for Security and Co-operation in Europe, while bearing in mind the enormous financial cost. Even then, they often come at the price of compromises and tradeoffs that may be perceived as arbitrary. For example, financial and logistical considerations largely explain why only Afghan refugees in Iran and Pakistan were allowed to take part in the 2004 presidential elections, whereas the less geographically concentrated Afghan refugees in the countries of Europe and North America were excluded (Long 2010).

Another difficulty stems from the identification and due registration of eligible refugee voters dispersed in a variety of countries. Refugees may be unwilling to communicate personal information to the authorities of their country of origin for fear of persecution or to the authorities of their host country for fear of compromising their legal status. Moreover, OCV processes necessarily require the cooperation of the host country, which may be unwilling to do so for international policy and domestic security reasons. The example of Uganda is illustrative in this respect, as refugees are explicitly discouraged from engaging in any political activities related to their country of origin in order to avoid the replication of ethnic or tribal divisions in the host country (Zakaryan 2018). At 
the same time, host countries may sometimes encourage refugees' participation in country-of-origin elections as a first step towards their repatriation. For instance, the Kenyan Government supported the OCV process for the 2011 referendum on the independence of South Sudan by deploying police on a 24-hour basis to all eight polling stations (Mathenge 2011). A total of 60,241 South Sudanese registered abroad, 15,062 of whom were in Kenya, where there were eight polling centres: two in Nairobi with 3,029 eligible voters; one in Dadaab with 171 registered voters; one in Eldoret, centre of the Rift Valley Province, with 1,359 voters; one in Kitale with 502 voters; one in Nakuru with 2,446 voters; and two in Kakuma with 5,524 voters (Osman 2011).

Another important challenge for OCV is linked to the potentially detrimental effects of formally enfranchising refugees. The tendency to treat refugee diasporas as a homogenous group whose members have the same preferences and interests could not be further from the truth (Brubaker 2005). Instead, diasporas are usually traversed by ideological cleavages that tend to be reinforced by the ethnic, religious or territorial divisions inherent in most contemporary conflicts (Wimmer 2012). Therefore, refugee diasporas should not prima facie be regarded as either agents of peace or agents of war, but as an internally divided section of the electorate. The risks are considerably amplified in the context of sectarian or tribal politics in the country of origin that is perpetuated among internally divided refugee diasporas along ethnic, tribal, religious or ideological lines (Baser 2015). This was clearly illustrated in the case of Congolese refugees in Uganda, who widely raised the perceived or actual threat to their personal security if they attempted to formally engage in Congolese politics, given the fact they were being hosted in Uganda and were therefore seen as collaborating with a foreign entity that has played a historical and is playing an ongoing role in the regional dynamics that are seen as fuelling instability in the DRC. A Congolese male refugee in Nakivale contextualized the limitations that refugee diasporans faces in attempting to support democracy building in their country of origin by noting:

[Participation] is not possible because the diaspora is seen as assisting rebels to fight the [country-of-origin] government.

—Congolese refugee 1, Nakivale 2017 (Zakaryan 2018: 22)

A group of Congolese refugee farmers in a focus group in Nakivale further reinforced this perception by stating:

People in Congo believe those in exile are preparing to wage war in Congo; therefore we cannot participate [politically] or go back.

—Congolese refugee focus group 1, Nakivale, 2017 (Zakaryan 2018: 22) 
The willingness of autocratic leaders to take the ballot to their populations abroad can also be part of a legitimization strategy. By demonstrating to the international community a dubious commitment to standard democratic practices, and by showing unexpected support from the diaspora in elections that are neither free nor fair, OCV can help to 'normalize' a pariah regime. The 2014 presidential election in Syria, which the regime framed as the first multiparty election in the country's history, provides a telling example. The franchise was expanded to officially registered refugees who were entitled to vote at Syrian embassies in host countries such as Iran, Jordan, Lebanon and Sweden. Refugees who were deemed to have 'fled illegally' were not eligible to vote (Associated Press in Sweden 2014). However, the elections were boycotted by opposition groups abroad and denounced as illegitimate by the European Union, while many countries such as Belgium, France, Germany, Turkey, the United Arab Emirates and the UK the Syrian embassies on their territories from conducting OCV (BBC News 2014; Reuters 2014).

In the case of Sweden, Syrians from opposing sides of the conflict gathered outside the Embassy in Stockholm to express their views and cast their ballots, with Assad supporters outnumbering those who opposed him (Associated Press Sweden 2014). Similarly, tens of thousands of Syrian refugees headed to the Syrian Embassy in Lebanon to vote in the 2014 presidential elections. In Lebanon news reports on OCV for Syria's 2014 presidential elections highlighted the chaos inside polling stations in the Syrian Embassy. Violence also erupted due to overcrowding in the vicinity of the Embassy (Attassi 2014). Furthermore, poll workers reportedly struggled to check voters' identification. It seems likely that there were a number of non-registered voters-otherwise preparations would have been made for the high number of registered voters - and that 'anyone could practically walk into the small and stuffy polling room and cast their ballot' (Attassi 2014). The result showed huge support for Assad among Syrian refugees in Lebanon (Associated Press in Lebanon 2014; Associated Press in Damascus 2014), which came as a surprise to the Lebanese population and many Lebanese politicians, and fuelled already entrenched popular resentment against refugees. As a result, in June 2014 the Lebanese Minister of the Interior issued a statement warning that Syrian refugees based in Lebanon should not travel to Syria, or their refugee status would be revoked. The Ministry announced that: 'this measure has been taken to safeguard Lebanon's security and relations between Syrian refugees and Lebanese citizens in host areas, and to prevent any friction or mutual antagonism' (Haid 2014).

However, it was also reported that one of the main reasons why Syrian refugees voted for Assad was fear of a backlash from the Syrian regime if they did not (Haid 2014). Al Jazeera reported that 'several opposition activists claim that officials from the Syrian Embassy have toured refugee encampments threatening that the regime would keep a record of all those who did not cast their 
ballots' (Attassi 2014). This poses serious questions about the integrity of the elections, given also that opponents of the Assad regime boycotted them, leading to a somewhat biased turnout. When asked about their interpretation of the massive turnout observed during these elections, some of the Syrian respondents in the Lebanon case study said that many of those who participated were forced to do so for fear of reprisals by the regime and its powerful supporters in Lebanon. Others, however, believed that people might have participated of their own accord because things had changed by 2014. Some Syrians interviewed in Lebanon believed that the Syrian refugees who voted were trying to 'restore relations' with the regime after they realized, three years into the crisis, that it would be impossible to remove it.

Syrians interviewed for this report in Germany and Turkey also expressed pessimism that political engagement with their country of origin could enhance democracy building. Given the limited political space and the continuing conflict in Syria, Syrian respondents saw no space for formal political participation at this stage. In fact, one female Syrian activist in Berlin perceived voting in the elections of her country of origin not as the exercise of a fundamental right, but as coercion to serve the purposes of the current regime:

It is not a real right, because you have to go and you have to vote for one person. No one will think of not going or voting against the president. So, I will not exercise my right because it is not done in the right way. [...] I think in general it is a good idea for people in the diaspora to have the ability to vote in the Syrian elections. But at this stage, it has no meaning or power to change anything. I don't think it will make a difference unless there are guarantees that voting will be free and fair.

—Syrian female respondent 4, Berlin, 2017 (Ragab 2018: 23)

With regard to participating in post-conflict Syrian elections in the future, many Syrian respondents in Turkey emphasized the importance of free and fair, multiparty and competitive elections that would allow for real change and highlighted the role of international election observers. A male refugee and development professional in Istanbul stated:

I would vote if there were free and fair elections monitored by different countries ... only if it is clear that the country is heading in a democratic direction.

-Syrian male refugee 1, development professional, Istanbul, 2017 (Mannix 2018: 20) 
Beyond OCV, refugees have the potential to participate in the formal political processes of their countries of origin by standing as candidates in transitional elections. This depends on the eligibility criteria for candidates in country-oforigin elections, as well as on the policies of both the host country and the country of origin regarding dual citizenship. While the number of countries that allow dual citizenship has increased in recent years, some countries (e.g. Azerbaijan, Botswana and Nepal) still do not do so while others (e.g. Egypt, Israel and Sri Lanka) do not allow dual nationality holders to run for office (Vink, de Groot and Luk 2015). Somalia's Constitution (2012) does not exclude dual passport holders from running for the presidency or participating in formal political processes (Gaffey 2017). Remarkably, of the 24 candidates standing in Somalia's presidential election in 2017, 16 held dual nationality (nine SomaliAmerican, four Somali-British and three Somali-Canadian). Members of the Somali diaspora are now highly visible in the senior leadership of political institutions as head of state, parliamentarians, cabinet members and officials. For example, the current President (Mohamed Abdullahi Farmajo) is a US-Somali dual citizen, while the current Prime Minister (Hassan Ali Khayre) and the current Speaker (Mohamed Osman Jawari) are Norwegian-Somali. Another example is the late Abass Abdullahi Sheikh Siraji, who grew up in the Dadaab refugee camp in Kenya and became Somalia's youngest cabinet member in 2017 when he was appointed minister of public works and reconstruction (Mohamed and Ibrahim 2017). Unfortunately, he was killed on 3 May 2017, underscoring refugees' fears of the risks associated with their active engagement in Somali politics (Opon 2018: 18).

In the same vein, many Afghans have returned to Afghanistan to take up senior positions in the government and political institutions. According to Afghan law, Afghans with dual nationality living in Afghanistan can stand for parliament and in provincial council elections or work as civil servants. Those who want to be nominated for a ministerial position or run in presidential elections, however, are required to renounce their foreign citizenship before their application or nomination can be considered (Afghanistan Independent Elections Commission 2014). Since the fall of the Taliban, Afghan refugees living abroad, including those who in the meantime had obtained citizenship in their host countries, have begun to show an interest in returning home to contribute to the democratic transition in their country. Several initiatives have been created to facilitate repatriation. For example, the IOM began helping Afghans living abroad to return, and facilitated their placement in key governmental and nongovernmental institutions under the Return of Qualified Afghans (RQA) programme (IOM 2008). The RQA programme helped skilled Afghans in the diaspora to access senior positions in the government and in non-governmental institutions in their home country. Former RQA beneficiaries went on to hold high-level positions in Afghanistan, including at one time or another the positions 
of Deputy President of Afghanistan, Minister of Justice, Chief of the Supreme Court and Minister of the Interior (IOM 2008).

As can be seen from the cases discussed above, refugees' capacity to genuinely participate in the formal political institutions and processes of their countries of origin depends to a large extent on the interaction between host and country of origin policies and interests, which influence each other, as well as on the international community, which can provide critical support for such processes. At the same time, however, the enfranchisement of refugees should not be taken as a compelling sign of democratization, but instead assessed cautiously and kept in context. In fact, in the aftermath of violence, an immediate introduction of universal suffrage in a highly polarized electorate can empower radical elites and extremist groups. Ultimately, while the inclusion of refugees in the formal political life of their countries of origin is key to reconciliation processes, other mechanisms for participation through diaspora organizations and by bringing legitimate and moderate elites to the negotiation table, as well as strengthening inclusive networks that cut across ethnic lines, may be more realistic options in the short term. 


\section{Non-formal political participation of refugees in their countries of origin}

Refugee populations settled in countries with a strong democratic tradition are increasingly portrayed as proxies for the diffusion of liberal and democratic norms in their country of origin (Docquier et al. 2016). This optimistic narrative sits alongside the darker one of the 'refugee warrior' (Zolberg, Suhrke and Aguayo 1989); both may be true to a certain degree among a diverse refugee population. Obviously, the former is far more conducive to the development of inclusive diaspora policies supported by international organizations, thus broadening the scope for political mobilization directed towards the country of origin. Nonformal political participation by the refugee diaspora in their countries of origin can take various forms, both positive and negative. Support may aim to promote peacebuilding by seeking alternatives to violence and democracy building through the diffusion of democratic ideas (Hammond et al. 2011). However, some diaspora funding and technical support are used to purchase arms or support insurgents. In addition, active mobilization takes place in the diaspora by word of mouth and the proliferation of pro-insurgent websites (Abdile 2010).

Political mobilization among refugee diasporas may also be instrumentalized by the host country for the pursuit of its own strategic aims. Conversely, in a context of de-alignment between the political agenda of organized refugee groups and the host country, the latter is likely to repress any form of collective mobilization that comes into stark conflict with its strategic national interests. Strong diaspora groups are therefore more likely to flourish in a host country in favour of, indifferent to or at least not fundamentally hostile to their country-of-origindirected political activities. 


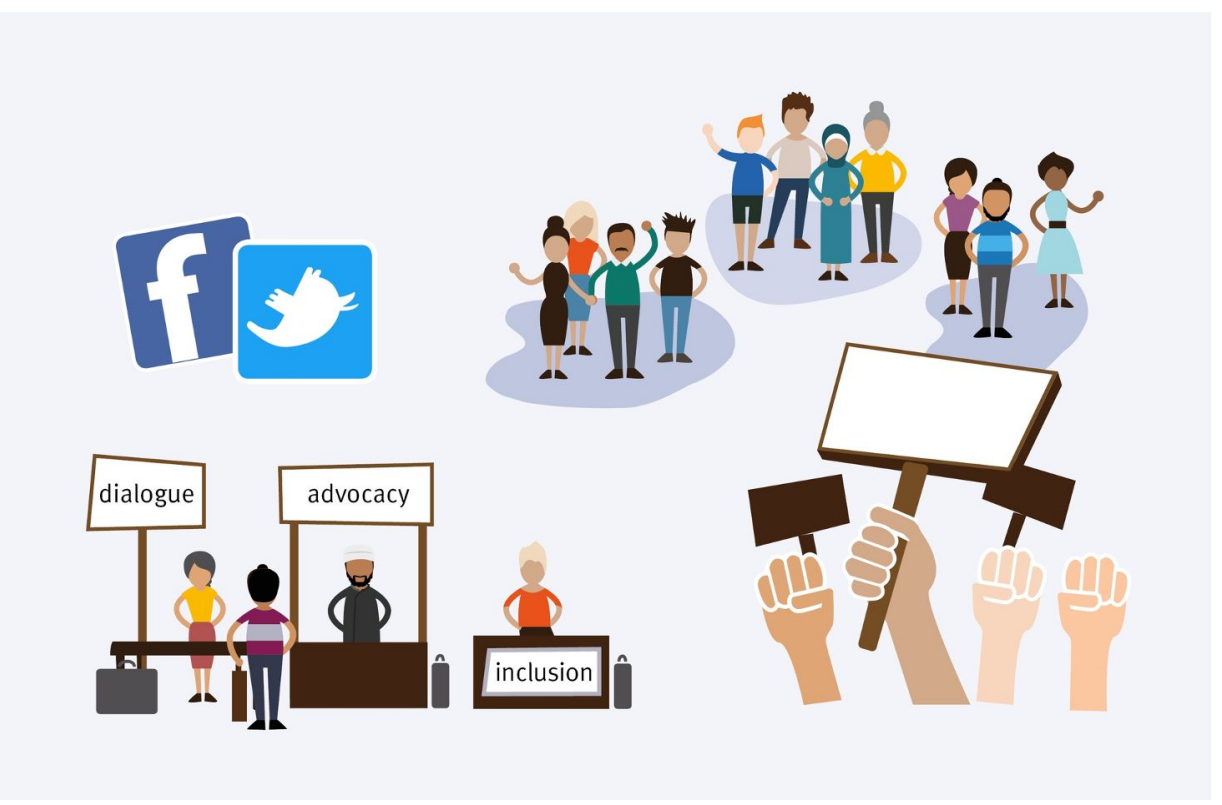

Figure 4. Mechanisms for non-formal political participation of refugees

\section{Civill society and diaspora organizations}

The refugee diaspora can initiate or contribute to policy dialogue at the national, regional or international levels, and serve as a bridge between host countries and countries of origin. Its members might also support the creation of transnational networks and CSOs with a focus on capacity-building among youth, education and the transfer of democratic values to their country of origin. During focus group discussions with Somali refugees in Stockholm, many participants recognized that the diaspora is a vital political asset and that they are connected to their country of origin in many ways, most notably through the implementation of humanitarian and development programmes in their home country:

By building schools and organizations in Somalia that educate the youth about democracy, the diaspora can help give Somali citizens the power to change their future.

-Somali refugee 1, Stockholm, 2017 (Adan 2018: 21)

The importance of civil society in bringing social and political change or transformation was also highlighted by Afghans interviewed in Germany. As 
sources of hope, these organizations, often led by the younger generation, tend to pursue non-violent, non-sectarian and liberal goals, and aim to promote alternative and progressive discourses in the conflict-affected societies.

In a similar way, South Sudanese and Congolese refugees in Uganda have established refugee-led organizations specific to their needs while in exile. For example, student associations allow refugees to unite under their national identity and deliberate on issues in their home countries. In focus groups in Kampala, members of both Congolese and South Sudanese student associations expressed their desire to create solidarity among refugee youth through education, and to relay the message of national, as opposed to tribal, unity as 'Congolese' or 'South Sudanese', given their shared experiences as refugees in Uganda (Zakaryan 2018: 22). A key example of this approach was provided by a South Sudanese student in Kampala: 'Our role is to create a single body with no tribalism and promote that we are all people of the same country' (Zakaryan 2018: 22).

Furthermore, as a Congolese refugee youth put it regarding his vision to build a more positive political climate in the DRC, 'We are the new generation and the Congo of tomorrow. We need to develop our skills so we can go back and develop our own country' (Zakaryan 2018: 22). A South Sudanese student refugee shared his perspective on the opportunities presented for refugee communities to be part of a broader diaspora network:

We enjoy freedom of expression and have the ability to create a peaceful vision of how South Sudan should be governed. The diaspora has an opportunity to participate in leadership and peacebuilding training in addition to being exposed to people from different backgrounds who come from stable countries and strengthen our perspectives on good governance.

—South Sudanese refugee 1, Kampala, 2017 (Zakaryan 2018: 22)

A South Sudanese refugee who has resided in Uganda for more than a decade and founded a refugee-led organization highlighted the importance of diversity and of educational opportunities as a means of drawing on the potential of younger generations of refugees. He described the mission of the organization as working for peaceful coexistence between refugees and Ugandan host communities: 
... educating youth in order to promote democracy through good governance and non-violence ... [our] motivation is to seek connections in our diversity.... We practise our commitment to peace by starting where we are and building a network across the African continent because refugees might repatriate but the network should persist.

—South Sudanese male refugee and NGO representative 4, Kampala, 2017 (Zakaryan 2018: 22)

Interviews with the Congolese community in South Africa found a highly active civil society led by Congolese refugees mobilizing its members to advocate for and contribute to change in their country of origin's tense political climate. Similar calls have been made by organizations such as the National Council of Congolese for Development, which, in addition to having direct links to opposition parties active in the DRC, has a large following among the Congolese diaspora-especially in Gauteng Province. As part of their activism, many of the leaders of refugee groups have strong links with and even hold senior positions in opposition parties in the DRC. Another example is the Congolese Community (COMCongo), which organized a meeting between a prominent member of Congo's Electoral Commission and the Congolese diaspora in the Western Cape. Among the issues discussed was the possibility of diaspora voting in the next DRC general elections. Furthermore, Congo Square News publishes a community newspaper in the Western Cape and works in the media space to share information on and raise awareness of matters of interest to the Congolese population, including current and political affairs. In addition to a newspaper, it also organizes and covers press conferences, community meetings and other activities convened by prominent opposition leaders and political actors in the DRC (Congo Square News 2016). It therefore plays an important role in linking up members of the diaspora community and keeping them abreast of developments in their home country. It is also involved in efforts to unify and organize Congolese people living in the Western Cape so that they speak with one voice and unite their efforts to contribute to peacebuilding in the DRC. Such CSOs work closely with churches and other faith-based organizations, including women's groups within the church, to offer support to the Congolese refugee and asylum seeker community.

In contrast, the field research in Kenya revealed that South Sudanese refugees there face particular challenges that restrict their participation in country-oforigin politics. They lack an urban-based coordination mechanism uncontaminated by home politics that could unite the South Sudanese diaspora to advocate for political change at home (Opon 2018: 20). During the focus group discussions with South Sudanese participants in Nairobi and Kakuma, it 
also became evident that the connections between them are based on face-to-face communication and historical or ethnic ties. They were therefore unaware of large South Sudanese diaspora networks and organized diaspora groups advocating to bring about political change in their home country. Nonetheless, many South Sudanese respondents - in both Nairobi and Kakuma—highlighted the potential for the diaspora to contribute to democracy building in their country of origin through the diffusion of democratic values and the implementation of civic education and human rights initiatives:

Democracy is a process and for South Sudan it can take time to grow.

I think the diaspora can play an important role in educating the South Sudanese people about democratic principles and about their rights as citizens.

—South Sudanese male refugee 1, Kakuma, 2017 (Opon 2018: 20)

Others stressed the importance of involving refugees from different ethnic backgrounds in the conduct of in-depth assessments with a view to understanding the root causes of the conflict and taking steps to overcome tribalism and ethnic divisions (Opon 2018).

In all the host countries where interviews with refugees were conducted, the Syrian civil society and diaspora organizations were among the most active. For instance, Citizens for Syria in Germany, established by Syrian activists in 2013, aims to build a broad base of social actors to raise awareness of the use of violence, and to promote aspirations of freedom, dignity, civil participation and shared development. The organization has established a globally networked platform for CSOs, as well as initiatives and activities to promote the development of independent civil society in Syria, and provides capacity-development training for Syrian NGOs inside and outside the country. A female Syrian activist interviewed in Berlin noted:

This can build responsibility, where we build political change because these are the people on the ground and not just people from the international community. Civil society even if it is not working directly in the political system can build a base for society, can react, act and criticize, can think and develop ideas and can participate and get politically involved, if they have the skills.

—Syrian female respondent 5, Berlin, 2017 (Ragab 2018: 25)

'Young leaders for Syria', jointly implemented by Citizen Diplomats for Syria, Friedenskreis Syrien and the European Foundation for Democracy, is another 
example. The project aims to build the capacity for political and social transformation in Syria and targets young Syrians from diverse backgrounds who have come to Germany since 2011. In a range of workshops, participants discuss topics such as identity, sectarianism, conflict narratives and conflict resolution. The main goal of the project is to develop a basis for democratic and inclusive development among the population of young Syrians in Germany. In addition, the objective is to promote participation in and integration into the local community through civic education and professional capacity-building.

Members of the Syrian Women's Network are part of the Syrian Women's Advisory Board, which was initiated by Staffan de Mistura, the UN special envoy for the Syrian crisis, to enable civil society participation in the Geneva peace talks. The main aim is to lobby for a commitment to gender-sensitive peacebuilding and reconstruction, while also enshrining the rights of women in Syria's future constitution. However, many of the Syrian respondents did not believe that the talks would have a genuine political impact and saw the discussions as disconnected from the reality on the ground in Syria (Ragab 2018).

In the case of Syrians in Lebanon, most respondents expressed the belief that they had a duty to help address the political and social challenges that their country of origin was facing, even if they did not currently live there. They were all motivated by the importance of having a say in the political processes in Syria and being able to influence the possible transition and course of reconstruction after the war was over. A female refugee and political activist in Beirut argued that: 'My priority is to contribute to building democracy in Syria after the war is over' (El-Helou 2018: 19). A male respondent noted the efforts of Syrian civil society to engage in the peace talks in Geneva:

I recently took part in the Syria peace talks in Geneva, where I was part of the civil society caucus. We were promoting our proposals for future alternatives for peace and development in Syria.

—Syrian male refugee and political activist 2, Beirut, 2017 (El-Helou 2018: 19)

In Turkey, too, the field research found a wide range of Syrian CSOs running cross-border operations inside Syria from Turkey, in an attempt to promote civil society growth and an inclusive and democratic future with long-term stability, or functioning as facilitators for cross-border capacity-building. Their work in Syrian communities in Turkey consists mainly of informing others, enlisting volunteers and acting as Arabic-language resource hubs and cultural centres. Examples include the non-profit Baytnasyria and the for-profit Trust Consultancy and Development Team. The latter employs mostly Syrians to design, monitor and evaluate projects inside Syria. This includes building the capacity of local, 
unelected community councils and CSOs to implement public works projects on a small scale, usually limited to water, sewage and electricity, in addition to community youth centres. A female refugee and learning/development professional in Gaziantep stated:

I am the secretary general of a working group for Syria, a political group that organizes Syrians who believe in democracy, freedom and human rights, and have secular views. We recruit members inside Syria and in the diaspora, and we support our members inside Syria to organize activities and campaigns in their local communities.

- Syrian female refugee 2, learning/development professional, Gaziantep, 2017 (Mannix 2018: 22)

An interesting example of a diaspora organization acting as the representative organ of an alternative political authority portrayed by its supporters as more legitimate than home state institutions is the case of the Syrian interim government-in-exile, which is the largest political group claiming to represent the Syrian diaspora in Turkey and worldwide. The Syrian interim government is a technical and representative alternative government, the aim of which is to represent the Syrian opposition on the ground in Syria and, prima facie, among the entire Syrian diaspora in Turkey and the world. Representatives are elected in an Internet election conducted by its umbrella organization, the National Coalition of Syrian Revolution and Opposition Forces (NCSROF n.d.). Formed in Qatar in 2012, the organization has had six presidents since 2012 and claims to be the sole representative opposition government body. The organization reportedly has a presence in Gaziantep, Istanbul and Ankara, but has increased operations in Azaz, just south of Turkey's Kilis Province. Its mission is to 'facilitate the transactions' of Syrian refugees in Turkey; coordinate with NGOs and other aid agencies for the benefit of refugees and the displaced inside Syria; and connect with the Turkish media to deliver a 'clear picture to the Turkish public about Syria' (NCSROF n.d.).

In November 2012 the Turkish Government recognized the group as the sole 'legitimate representative' of the Syrian people. The group claimed to represent 80 per cent of President Assad's opponents at that time (RIA Novosti 2012). However, none of the group's dozens of representatives are elected by a plurality of Syrian refugees. Rather, they are elected online by a limited number of politically active diaspora citizens. According to a Syrian refugee and political activist interviewed for the Turkey case study, its governing council of 110 people includes various ethnic minorities such as Turkmens and Kurds, but only five women and no youth representation. Many of the Syrians interviewed in Turkey highlighted the ineffectiveness of the council in improving their livelihoods and 
advancing peace and democracy building inside Syria (Mannix 2018). On the other hand, a former representative of the group's governing council interviewed for the Turkey case study was more optimistic about the prospects for a successful government-in-exile, noting that the interim government had ministers in Homs and other 'liberated' areas. It also maintains regular contact between activists in Turkey and Syria, even in the form of visits (Mannix 2018: 21).

\section{Protests and other forms of transnational political activism}

In addition to membership of CSOs and diaspora organizations, refugees have a right to be considered citizens in their country of origin, and to participate in the governing of their own political community, including through peaceful political protest against the government of their country of origin while in exile (Long 2010).

In particular, some of the Syrian respondents interviewed in Sweden noted that when they consider it necessary, they carry out community mobilization and organize demonstrations to draw attention to the situation in their homeland. To this end, Syrian participants acknowledged the potential for the refugee diaspora to put pressure on the host country and the international community about issues related to their country of origin, and the importance of not having to fear repression. Syrian activists outside the country are mainly involved in connecting the voices of protesters inside the country to the outside world, by disseminating information about the Syrian civil war and collaborating with professional journalists to raise awareness of the situation in Syria among the public (AndénPapadopoulos and Pantti 2013). For instance, a Syrian refugee in Malmö 'participated in many protests in Stockholm against the war in Syria and in solidarity with the people in my country. ... It is important to express our voice and to unite for peace and democracy in my country' (Adan 2018: 21).

At the same time, it was also noted that Syrian activists often refrain from participating in protests for fear of reprisals against family members still living in Syria. According to some of the respondents, in the past the Syrian security forces have resorted to detaining relatives and neighbours to discourage government critics. A Syrian staff member at the Swedish Labour Office in Stockholm told how: 'Because of the ongoing conflict in Syria and the family connection, it is very hard for Syrians to share information with you ... even most of the fellow Syrian refugees keep their distance from me and have doubts about my work' (Adan 2018: 21). Similar findings have emerged from other studies conducted among the Syrian refugee diaspora in Sweden. These indicate that diaspora mobilization is hindered significantly by surveillance, intelligence reports, and threats against activists abroad and their family members still living in their country of origin (Lundgren 2015). 
Interviews with South Sudanese refugees in Kenya reveal similar fears. The kidnap of South Sudanese political activists and opposition supporters in Nairobi in January 2017, who were forcefully returned to South Sudan, has served as a warning, halting any political discussion among refugees on the unravelling situation in South Sudan (Houreld 2017). As one female South Sudanese refugee in Nairobi noted, 'One of the main challenges [to direct engagement in our country-of-origin politics] is that activists in the diaspora risk being kidnapped or killed' (Opon 2018: 19). The risk of deportations, in combination with deep ethnic divides that are replicated in the host country, contribute to the suppression of the political voice of the South Sudanese refugee community in Kenya and discourage political behaviour that would usually be expected in similar circumstances.

Concerns about deportation or the revocation of refugee status if caught participating in protests were raised by Somali refugees in Kenya and by many Congolese respondents in South Africa. Nonetheless, organizations such as the Congolese Community in the Western Cape (CCWC) and the Congolese Community in South Africa (CCSA), working alone or with others, have organized national and local protests against the political situation and recent developments in the DRC. These have targeted key strategic points such as the Embassy of the Democratic Republic of the Congo, the Union Buildings, the South African Parliament and even the headquarters of political parties, including the ANC (Mpeiwa 2018). During the interviews some of the Congolese respondents recalled how on 24 June 2017 members of the CCSA organized a protest outside the Presidential Guesthouse in Pretoria on the occasion of President Kabila's state visit to South Africa. Some of the respondents had participated in the protest, and said that the objective was to express their unhappiness with what they considered to be 'President Kabila's unconstitutional, illegal regime'. This was a follow-up protest to one held at the DRC Embassy in December 2016 after elections were postponed indefinitely. The 2016 protest, which was part of a global campaign, had turned violent and ultimately required police intervention to disperse the crowds. Some of the political activists among the refugee leaders interviewed for this research blamed the violence on 'infiltrators who come to the protests pretending to be protesters, in order to instigate violence among the protesters and also to provoke the police, so that they ultimately discredit the organizers in South Africa' (Mpeiwa 2018: 20).

The use of social media was also identified as an important avenue for members of the refugee diaspora to express their political views and engage in political debate. One example is a Facebook group with more than 6,000 members of the Sweden-based Somali diaspora, where followers can discuss different events and developments related to their country of origin (Adan 2018). A Somali naturalized refugee in Stockholm stated: 
[The] Somali diaspora can have an important impact on the political life of my country of origin. They campaign and collect money for many politicians they wish to support. Thus, they have the power to support a party or politician who has the potential to implement democracy.

—Somali naturalized refugee 3, Stockholm, 2017 (Adan 2018: 19)

Social media have also enabled Afghan refugees to participate in non-formal and indirect political activities in their country of origin. Almost all the Afghan respondents interviewed in the UK said that they follow their country of origin's politics very closely on social media. Some argued that now they are beyond the reach of threats and intimidation, they can express their views freely about political developments back home. There are many examples of social media lobbying for specific leaders or political parties in Afghanistan by UK-based Afghan refugees. Such initiatives are often not initiated by the political parties in Afghanistan, but put together voluntarily by members of the diaspora sympathetic to a particular leader or party. It seems that non-formal political engagement by Afghan refugees and asylum seekers on social media platforms is not limited to routine individual streaming. According to the London-based Afghan Voice Radio, on the eve of Afghanistan's 2014 presidential election a group of Afghan refugees based in the UK used a multimedia platform that included Google Talk, Twitter and Facebook to create an international debate among educated Afghan refugees under the heading 'National Compact' (Ghani 2013). According to a young refugee who participated in the National Compact:

The group started live discussions with Ashraf Ghani, one of the then presidential nominees [candidates] who is now the President of Afghanistan. One of the main organizers of this unique Afghan diaspora discussion was later picked by President Ghani and appointed to a very high government position in Afghanistan. Technology helped us go beyond the barriers of refugee life.

-Young refugee and participant in the National Compact, London, 2017 (Sharifi 2018: 21)

To conclude, non-formal means of political participation-be they through CSOs, protests or grassroots initiatives - offer ways for refugees to connect with their countries of origin. Such means are often the only avenue open for political engagement, as formal channels of participation may not be available. However, as several of the case studies show, these do not always happen because of the real or perceived security risks involved in non-formal engagement, particularly when 
the national strategic agenda of the host country is at odds with the cause of a community of refugees or when the mobilization of refugees is perceived as a potential threat to the security of the host country. Furthermore, refugees are often reluctant to engage and become vocal either because they fear losing their refugee status and being deported to their country of origin, or because they fear reprisal from supporters of the country-of-origin regime against them or their families back home. In this regard, host countries have a key role to play in providing a safe forum for freedom of expression. 


\section{Conclusion and recommendations}

This report has examined eight host countries and five countries of origin with high numbers of refugees. While the field research and qualitative analysis are not exhaustive and do not allow for generalization, the report outlines the challenges and opportunities refugees face with regard to political participation and provides unique insights into their experiences with a wide range of mechanisms for formal and non-formal political participation.

The report's findings suggest that the legal and practical restrictions on access to citizenship by long-term refugees significantly affect their opportunities for acquiring formal electoral rights in their host country. With the exception of the Swedish case, where refugees are granted the right to vote in regional and municipal elections, the acquisition of citizenship through naturalization in all other host countries discussed in this report remains an essential precondition for full and equal electoral rights for refugees. Refugees' opportunities to be naturalized vary widely. Some countries such as Sweden facilitate their access while others, such as Kenya, Lebanon and Uganda, practically bar them from acquiring citizenship.

Non-formal means of participation, such as consultative bodies, CSOs or protests, are often the only way for refugees to exercise political expression, in relation to both the host country and their country of origin. However, such means cannot replace formal engagement in political life. Instead, they should be considered complementary or intermediary steps on the way to a durable solution such as naturalization or voluntary repatriation.

Refugees still face distinct challenges in making use of their electoral rights in country-of-origin elections, due either to the lack of regulated mechanisms for $\mathrm{OCV}$ or to the lack of serious commitment by governments in their countries of 
origin to conduct free and fair elections. At the same time, issues surrounding refugees' registration as voters and the modalities for voting in country-of-origin elections must be carefully addressed to mitigate the diffusion of sectarian or ethnic tensions from the domestic arena to the diaspora. Despite the restrictions on formal political participation, refugee diasporas have the potential to play an important role in peace- and democracy-building in their countries of origin. Their engagement through non-formal mechanisms of political participation such as civil society and diaspora organizations, protests and other forms of transnational activism-including the use of social media tools-presents notable opportunities for mobilizing refugee diasporas beyond the borders of their host countries. These mechanisms and tools can also serve as important ways of connecting refugees to their countries of origin, as well as of raising awareness among the international community of political developments in their countries of origin and exercising pressure on their host countries to act in support of democracy in the countries of origin. Hence, refugee politics and policies in countries of origin and host countries influence each other and reinforce the role of refugees as dual political actors.

\section{Recommendations}

In light of the above, the following recommendations are made to enhance the political participation of refugees.

\section{For governments in host countries}

- Implement the commitment in article 34 of the 1951 Refugee Convention on naturalization, which would ease naturalization for refugees by lowering requirements, providing concise information on those requirements and ensuring transparency in naturalization procedures, with special attention to groups affected by double marginalization such as refugee women.

- Consider extending or expanding electoral rights in local and regional elections to refugees who are long-term residents. This would enable refugees to participate in formal electoral processes and political decisionmaking at the local level and enhance their sense of belonging in the host society.

- If the host country does not already do so, enable self-organization of refugees through CSOs, thereby ensuring freedom of expression and association for refugees.

- If the context allows, state and local governments should enhance the support provided to migrant representative bodies and refugee-led organizations through the provision of funding and capacity-building, 
thereby incentivizing the integration of refugees into the host society and creating opportunities for interaction between refugees and the settled population.

- Local authorities and civil society should implement joint programmes aimed at providing information, capacity-building and political empowerment, in particular for refugee women and youth, to help them understand the mechanisms for formal and non-formal political participation in the host country and the various avenues for contributing to peace- and democracy-building in their host countries and countries of origin.

- State and local governments should conduct consultations with diaspora groups and community organizations to inform decision-makers of refugee needs, especially prior to amending any processes that could affect their legal status or well-being. This would increase the likelihood of compliance and allow those refugees who are in all other respects integrated locally to participate in local political structures, ensuring their full inclusion among broader host communities.

\section{For governments in countries of origin}

- Explore means to facilitate OCV for presidential, legislative and transitional post-conflict elections. A starting point would be dialogue between host and country-of-origin governments, and representatives of the refugee diaspora. This should be done in a transparent manner that builds trust in a free and fair voting process. Provisions and operations should be fully functional to ensure diaspora trust in the voting processes, avoid intimidation and voter fraud, and ensure the sustainability of electoral outcomes.

- Conduct outreach in countries where there are large diaspora communities, to inform them of their rights and encourage them to participate in their country of origin's political processes. Technological solutions and ICT tools can facilitate this.

- Collaborate with CSOs and diaspora groups to implement civic education and voter information programmes, as well as awareness-raising and informative campaigns about democratic processes in countries of origin, and offer means for the diaspora to get involved.

- Put in place mechanisms for engagement, participation by and consultations with refugee diaspora during peace negotiations, transition processes and/or future electoral processes. 


\section{For political parties in host countries}

- Develop strategies and platforms for engaging with refugee groups to promote social cohesion and diversity within the party. Promote diversity and equal opportunities by nominating more candidates from refugee backgrounds and placing them in positions on party lists where they have a genuine chance of getting elected.

\section{For political parties in countries of origin}

- Seek ways to expand membership of political parties from among the diaspora. This will increase diversity and representation within parties, and contribute to enhancing the quality of democracy in countries of origin.

\section{For civil society in host countries and countries of origin}

- Facilitate the establishment of platforms or committees for refugees to make their voices heard in their host communities, especially on issues that matter to them such as basic services, education, health, and civil and political participation.

- Create and strengthen diaspora networks in order to benefit from the knowledge, experience and financial resources available among the refugee population and their advocacy for democratic change.

- Diaspora organizations and civil society should consider the establishment of alternative platforms for dialogue and engagement in country-of-origin politics. These coalitions between civil society and diaspora organizations should also be strengthened and mobilize themselves as stakeholders in the political affairs of countries of origin. This could encourage highly skilled and motivated members of the diaspora to contribute to nation-building and democratization in their countries of origin.

\section{For international and regional organizations}

- International and regional organizations should use their infrastructure and capacity to organize and support the integrity of OCV processes.

- Support the inclusion of mechanisms for engagement with, participation by and consultations with refugee diaspora during peace negotiations, transition processes and/or future electoral processes. 
Abdile, M., 'Diasporas and their role in the homeland conflicts and peacebuilding: the case of Somali diaspora', Diasporas for Peace

(DIASPEACE) Working Paper No. 7 (November 2010), <https://jyx.jyu.fi/ dspace/bitstream/handle/123456789/36881/DIASPEACE_WP7.pdf?se>, accessed 9 August 2017

Adan, T., Political Participation of Refugees: The Case of Syrian and Somali Refugees in Sweden (Stockholm: International IDEA, 2018), <https://www.idea.int/ publications/catalogue/political-participation-refugees-bridging-gaps $>$, accessed 7 April 2018

African National Congress, 'African National Congress Constitution', as amended in 2012, <http://www.anc.org.za/docs/const/2012/const.pdf>, accessed 18 August 2017

Al Jazeera, 'Syrian refugees could become Turkish citizens', 4 July 2016, <http:// www.aljazeera.com/news/2016/07/erdogan-syrian-refugees-turkishcitizens-160703133739430.html>, accessed 20 July 2017

—, 'Erdogan offers citizenship to Syrian and Iraqi refugees', 7 January 2017a, $<$ http://www.aljazeera.com/news/2017/01/erdogan-offers-citizenship-syrianiraqi-refugees-170106195134961.html>, accessed 20 July 2017

—, 'Lebanon: Army raids Arsal refugee camps, one killed', 30 June 2017b, $<$ http://www.aljazeera.com/news/2017/06/lebanon-soldiers-wounded-arsalrefugee-camp-raid-170630045304436.html>, accessed 26 June 2017 
Andén-Papadopoulos, K. and Pantti, M., 'The media work of Syrian diaspora activists: brokering between the protest and mainstream media', International Journal of Communication, 7 (2013), pp. 2185-206

Arrighi, J. T. and Bauböck, R., 'A multilevel puzzle: migrants' voting rights in national and local elections', European Journal of Political Research, 56/3 (2017), pp. 619-39

Associated Press in Damascus, 'Bashar al-Assad wins re-election in Syria as uprising against him rages on', The Guardian, 4 June 2014, <https:// www.theguardian.com/world/2014/jun/04/bashar-al-assad-winds-reelectionin-landslide-victory>, accessed 21 June 2017

Associated Press in Lebanon, 'Syrians in Lebanon battle crowds to vote for Bashar al-Assad', The Guardian, 28 May 2014, <https:/www.theguardian.com/ world/2014/may/28/syrians-lebaanon-vote-assad-embassies-refugeesboycott>, accessed 10 June 2017

Associated Press in Sweden, 'Assad's supporters abroad vote in Syrian election', Daily Mail, 28 May 2014,<http://www.dailymail.co.uk/wires/ap/ article-2641386/Assads-supporters-abroad-vote-Syrian-election.html>, accessed 9 June 2017

Asylum Information Database (AIDA), 'Country Report: United Kingdom', 31 December 2016, <http:/www.asylumineurope.org/sites/default/files/reportdownload/aida_uk_2016update.pdf>, accessed 31 July 2017

Ataç, I., Rygiel, K. and Stierl, M., 'Introduction: The contentious politics of refugee and migrant protest and solidarity movements: remaking citizenship from the margins', Citizenship Studies, 20/5 (2016), pp. 527-44

Attassi, B., 'Huge turnout for Syrian vote in Lebanon', Al Jazeera, 28 May 2014, <http://www.aljazeera.com/news/middleeast/2014/05/syrian-expats-dividedover-presidential-vote-2014528102522416850.html>, accessed 10 October 2017

Baladi, E., 'Will Syrians born in Turkey receive Turkish citizenship?', Syrian Observer, 4 November 2015, <http://syrianobserver.com/EN/News/30082/ Will_Syrians_Born_Turkey_Receive_Turkish_Citizenship $>$, accessed 19 July 2017

Baser, B., Diasporas and Homeland Conflicts: A Comparative Perspective (Farnham: Ashgate Publishing, 2015) 
BBC News, 'Syria election: refugees vote in Lebanon and Jordan', 28 May 2014, <http://www.bbc.com/news/world-middle-east-27599868>, accessed 7 March 2018

BBC News Persian, 'British elections and Afghan voters', 1 May 2015, <http:// www.bbc.com/persian/afghanistan/2015/05/150501_fm_ali_salimi_ afghans_uk_election>, accessed 30 July 2017

Bernitz, H., 'Access to electoral rights: Sweden', EUDO Citizenship Observatory, June 2013, <http://cadmus.eui.eu/handle/1814/29826>, accessed 3 April 2018

Betts, A. and Jones, W., Mobilising the Diaspora: How Refugees Challenge Authoritarianism (Cambridge: Cambridge University Press, 2016)

P. Bevelander and M. Spång (eds), 'Valdeltagande och Representation - Om Invandring och Politisk Integration i Sverige' [Voter participation and representation: Immigration and political integration in Sweden] (Stockholm: Delegationen för migrationsstudier, 2017), <http:// www.delmi.se/publikationer-seminarier\#!/valdeltatande-och-representationominvandring-och-politisk-integration-i-sverige-rapport-och-policy>, accessed 5 October 2017

Bivald, K., Hertz, T., Qvist, M. and Soininen, M., Challenges for Diversity: Migrant Participation in Political Parties in Sweden (Stockholm: Stockholm University, June 2014), <https://www.cjd-nord.de/fileadmin/assets/nord/ Downloads/Migration_Forschung_Beratung/Downloads/Country_Reports/ DivPol_Swedish_Report.pdf>, accessed 3 April 2018

Blinder, S., Naturalisation as a British Citizen: Concepts and Trends (Oxford: The Migration Observatory at the University of Oxford, 2017), <http:// www.migrationobservatory.ox.ac.uk/wp-content/uploads/2016/04/BriefingNaturalisation-2017.pdf>, accessed 15 August 2017

Bloemraad, I., 'Accessing the corridors of power: puzzles and pathways to understanding minority representation', West European Politics, $36 / 3$ (2013), pp. $652-70$

Brand, L. A., 'Arab uprisings and the changing frontiers of transnational citizenship: voting from abroad in political transitions', Political Geography, 41 (2014), pp. 54-63 
Brinkerhoff, J. M., 'Diasporas and Conflict Societies: Conflict Entrepreneurs, Competing Interests, or Contributors to Stability and Development', Paper presented at the international workshop 'Global Effects and Local Dynamics of Intrastate Conflict', Jerusalem, 17-19 May 2009

Brubaker, R., 'The "diaspora” diaspora', Ethnic and Racial Studies, 28/1 (2005), pp. 1-19

Bundesamt für Migration und Flüchtlinge [German Federal Office for Migration and Refugees, BAMF], 'Strukturförderung von Migrantenorganisationen, 2016' [Structural support of migrant organizations, 2016], <http://www.bamf.de/DE/Infothek/Projekttraeger/Strukturfoerderung-MO/ strukturfoerderung-mo-node.html>, accessed 1 May 2017

Bündnis 90/Die Grünen [Alliance 90/The Greens], 'Grüne Regeln: Satzung, Frauenstatut, Beitrags- und Kassenordnung, Schiedsgerichtsordnung, Urabstimmungsordnung' [Green Rules: Statute, Women's Statute, Contribution and Fund Regulations, Arbitration Rules, Ballot Rules] (Berlin: Bündnis 90/Die Grünen, 2016), <https://www.gruene.de/ fileadmin/user_upload/Dokumente/Satzung/Satzung_Bundesverband.pdf>, accessed 14 March 2018

Çetingüleç, T., 'Syrians shifting demographics in Turkey's Kurdish regions', AlMonitor, 10 August 2016, <http://www.al-monitor.com/pulse/originals/ 2016/08/turkey-syria-syrian-refugees-kurdish-region.html>, accessed 20 July 2017

Change Institute, The Afghan Muslim Community in England: Understanding Muslim Ethnic Communities (London: Department for Communities and Local Government, April 2009), <http://www.communities.gov.uk/ documents/communities/pdf/1203127.pdf>, accessed 3 April 2018

Charity Commission, 'How to set up a charity (CC21a)', 20 May 2014, <https:// www.gov.uk/guidance/how-to-set-up-a-charity-cc21a>, accessed 24 April 2018

Chimni, B. S., 'From resettlement to involuntary repatriation: towards a critical history of durable solutions to refugee problems', Refugee Survey Quarterly, 23/3 (2004), pp. 55-73

Christlich Demokratische Union Deutschlands [Christian Democratic Union of Germany, CDU], Statutenbroschüre der CDU Deutschlands [Statutes 
brochure of the CDU], 2016, <https://www.cdu.de/system/tdf/media/ statutenbroschuere.pdf?file $=1>$ accessed November 2017

Citizens for Syria, 'List of organizations', [n.d.], <https://citizensforsyria.org/ mapping-syrian-cs/simplesearch/>, accessed 20 July 2017

Collyer, M., 'A geography of extra-territorial citizenship: explanations of external voting', Migration Studies, 2/1 (2014), pp. 55-72

Congo Square News, 'Memorandum of the Congolese civil society in South Africa dropped to the South Africa Parliament the 16th February 2016', 16 February 2016, <https://congosquarenews.wordpress.com/2016/02/19/ memorandum-of-the-congolese-civil-society-in-south-africa-dropped-to-thesouth-africa-parliament-the-16th-february-2016/>, accessed 5 May 2017

Council of Europe, Convention on the Participation of Foreigners in Public Life at Local Level, European Treaty Series No. 144, 5 February 1992, <https:// rm.coe.int/168007bd26>, accessed 12 March

Christlich-Soziale Union [Christian Social Union, CSU], 'Satzung der ChristlichSozialen Union' [Statutes of the Christian Social Union], 2016, <http:// www.csu.de/common/csu/content/csu/hauptnavigation/partei/satzung/ CSU-Satzung-2017-ES.pdf>, accessed 7 March 2018

Dahl, R., Democracy and its Critics (New Haven: Yale University Press, 1989)

Dähnke, I., Markard, L., Wiesner, A. and Zapata-Barrero, R., Diversity in Political Parties' Programmes, Organisation and Representation (DIVPOL): Final Report (Hamburg, DIVPOL, 2014), <http://www.migpolgroup.com/ portfolio/diversity-political-parties-programmes-organisation-representationfinal-report>, accessed 9 August 2017

Daily Star [Lebanon], 'Lebanon will not naturalize refugees', 1 April 2017, <http://www.dailystar.com.lb/News/Lebanon-News/2017/Apr-01/400115lebanon-will-not-naturalize-refugees-bassil.ashx>, accessed 9 June 2017

Dancygier, R., Lindgren, K., Oskarsson, S. and Vernby, K., 'Why are immigrants in politics? Evidence from Sweden', American Political Science Review, 109/4 (November 2015), <https://scholar.princeton.edu/sites/default/files/ rdancygi/files/dlov_2015.pdf>, accessed 9 August 2017

Democratic Alliance [South Africa], 'Federal Constitution', 2015, $<$ http://www.da.org.za/wp-content/uploads/2013/12/DA-Federal- 
Constitution-approved-by-Congress-9-May-2015.pdf>, accessed 7 June 2017

Die Linke [The Left], 'Bundessatzung der Partei Die Linke' [Federal Statutes of the Left Party], 2016, <https://www.die-linke.de/partei/ grundsatzdokumente/bundessatzung/>, accessed 7 March 2018

Dietz, B., Eißel, D. and Naumann, D., Handbuch der kommunalen Sozialpolitik [Manual of municipal social policy] (Wiesbaden: Springer-Verlag, 2013)

Docquier, F., Lodigiani, E., Rapoport, H. and Schiff, M., 'Emigration and democracy', Journal of Development Economics, 120 (2016), pp. 209-23

Durieux, J.-F., 'Temporary protection: hovering at the edges of refugee law', in M. Ambrus and R. A. Wessel (eds), Netherlands Yearbook of International Law 2014 (The Hague: TMC Asser Press, 2015), pp. 221-53

Earnest, D. C., 'The enfranchisement of resident aliens: variations and explanations', Democratization, 22/5 (2015), pp. 861-83

Ebead, N. and McDonough, P., 'Migration, social polarization, citizenship and multiculturalism', in International IDEA, The Global State of Democracy: Exploring Democracy's Resilience (Stockholm: International IDEA, 2017), <https://www.idea.int/gsod/\#chapter-7>, accessed 26 March 2018

Elbayar, K., 'NGO laws in selected Arab states', International Journal of Not-forProfit Law, 7/4 (September 2005), pp. 3-27, <http://www.icnl.org/research/ journal/vol7iss4/special_1.htm>, accessed 6 April 2018

El-Helou, Z., Political Participation of Refugees: The Case of Syrian Refugees in Lebanon (Stockholm: International IDEA, 2018), <https:/www.idea.int/ publications/catalogue/political-participation-refugees-bridging-gaps>, accessed 7 April 2018

Escobar, C., Migration and Franchise Expansion in Latin America (San Domenico di Fiesole: GLOBALCIT Observatory Country Report Series, 2017)

European Commission, 'Lebanon: Syria Crisis', ECHO Factsheet, March 2017, <https:/ec.europa.eu/echo/files/aid/countries/factsheets/ lebanon_syrian_crisis_en.pdf>, accessed 7 June 2017

European Endowment for Democracy, 'Touch of a rose: reaching out to Syrian refugees in Lebanon', 10 July 2017, <https:// 
www.democracyendowment.eu/news/touch-of-a-rose-reaching-out-tosyrian-refugees-in-lebanon/>, accessed 21 March 2017

European Parliament and European Council, 'Regulation (EU) No 604/2013 of the European Parliament and of the Council of 26 June 2013', Official Journal of the European Union, L 180/31, 29 June 2013, <http://eurlex.europa.eu/legal-content/EN/TXT/PDF/?uri=CELEX: 32013R0604\&from=EN>, accessed 23 March 2018

European Union Agency for Fundamental Rights (FRA), Together in the EU: Promoting the Participation of Migrants and their Descendants (Luxembourg: FRA, 2017), <http://fra.europa.eu/en/publication/2017/migrantparticipation>, accessed 7 March 2018

European University Institute, Global Governance Programme, Global Database on Modes of Acquisition of Citizenship (GLOBALCIT), <http:// globalcit.eu/acquisition-citizenship>, accessed 7 February 2018

Expressen, 'Allt du behöver veta om politikerveckan i Järva 2017' [All you need to know about the Political Week in Järva], 7 June 2017, <https:// www.expressen.se/nyheter/allt-du-behover-veta-om-politikerveckan-ijarva-2017/>, accessed 30 September 2017

Faist, T., 'Staatsbürgerschaft und Integration in Deutschland: Assimilation, kultureller Plurtranalismus und Transstaatlichkeit' [Citizenship and integration in Germany: assimilation, cultural pluralism and transnationality], in Y. Bizeul (ed.), Integration von Migranten: Französische und deutsche Konzepte im Vergleich [Integration of migrants: French and German concepts compared] (Wiesbaden: Deutscher Universitätsverlag, 2013), pp. 77-104

Ferguson, D., 'Want to get involved in party politics? It costs less than you think', The Guardian, 13 June 2015, <https://www.theguardian.com/money/2015/ jun/13/party-politics-cost-getting-involved-pitfalls>, accessed 21 July 2017

Francis, E., 'Hostility grows towards Syrian refugees in Lebanon', Reuters, 28 August 2017, <https://www.reuters.com/article/us-lebanon-refugeestension/hostility-grows-towards-syrian-refugees-in-lebanonidUSKCN1B8128>, accessed 10 October 2017

Gaffey, C., 'Five things you should know about Somalia's election', Newsweek, 8 February 2017, <http://www.newsweek.com/somalia-elections-somaliapresident-554028>, accessed 9 August 2017 
Garlick, M. et al., Building on the Foundation: Formative Evaluation of the Refugee Status Determination (RSD) Transition Process in Kenya, PDES/2015/01 (Geneva: UNHCR Policy Development and Evaluation Service, April 2015), <http://www.unhcr.org/5551f3c49.html>, accessed 2 March 2018

Gesemann, F. and Roth, R., Integration ist (auch) Ländersache: Schritte zur politischen Inklusion von Migrantinnen und Migranten in den Bundesländern [Integration is (also) a matter for the states: steps towards the political inclusion of migrants in the federal states] (Berlin: Friedrich-Ebert-Stiftung Forum, 2014), <http://library.fes.de/pdf-files/dialog/10528version-20140317.pdf>, accessed 15 March 2018

Gesemann, F., Roth, R. and Aumüller, J., Stand der kommunalen Integrationspolitik in Deutschland [State of municipal integration policy in Germany] (Berlin: Instituts für Demokratische Entwicklung und Soziale Integration, 2012), <https:/www.bundesregierung.de/Content/DE/ Publikation/IB/2012-05-04-kommunalstudie.html>, accessed 6 April 2018

Ghani, A., 'National Compact' [live stream of first national debate], YouTube, 7 July 2013, <https://www.youtube.com/watch? v=Ez6Mtw7iTEI\&feature=youtu.be $>$, accessed 31 July 2017

Girit, S., 'Turks hit back at Erdogan plan to give Syrian citizenship', BBC News, 5 July 2016, <http://www.bbc.com/news/world-europe-36704791>, accessed 20 July 2017

Global Village, Homepage, <http://theglobalvillage.se/>, accessed 12 December 2017

Goodman, S. W., 'Fortifying citizenship: policy strategies for civic integration in Western Europe', World Politics, 64/4 (2012), pp. 659-98

Government Offices of Sweden, 'Swedish citizenship (Summary)', 17 May 2015, <http://www.government.se/legal-documents/2013/04/sou-201329/>, accessed 9 June 2017

Haid, H., 'The Syrian President is being made in Lebanon? Rumours and the Syrian presidential election in Lebanon', Heinrich Böll Stiftung, 5 November 2014, <https://b.boell.org/en/2014/11/05/syrian-presidentbeing-made-lebanon-rumours-and-syrian-presidential-election-lebanon>, accessed 24 June 2017 
Hailbronner, K., EUDO Citizenship Observatory Country Report: Germany (Fiesole: European University Institute, Robert Schuman Centre for Advanced Studies, 2010), <http://cadmus.eui.eu//handle/1814/19614>, accessed 4 April 2018

Hainmueller, J., Hangartner, D. and Lawrence, D., 'When lives are put on hold: lengthy asylum processes decrease employment among refugees', Social Advances, 2/8 (2016), pp. 1-7

Hammond, L. et al., Cash and Compassion: The Role of the Somali Diaspora in Relief, Development and Peace-building (Washington, DC: United Nations Development Programme, 2011)

Harpaz, Y., 'Ancestry into opportunity: how global inequality drives demand for long-distance European Union citizenship', Journal of Ethnic and Migration Studies, 41/13 (2015), pp. 2081-104

Hartmann, C., 'Expatriates as voters? The new dynamics of external voting in sub-Saharan Africa', Democratization, 22/5 (2015), pp. 906-26

Home Office (UK), 'Fees with effect from 6 April 2017 for Citizenship Applications and the Right of Abode', [n.d], <https:/www.gov.uk/ government/publications/fees-for-citizenship-applications $>$, accessed 3 April 2018

—, 'Nationality policy: naturalisation as a British citizen by discretion', 2017, <https://www.gov.uk/government/uploads/system/uploads/ attachment_data/file/632935/naturalisation-as-a-British-citizen-bydiscretion-v1.0.pdf>, accessed 11 February 2018

Hourani, G. and Sensenig-Dabbous, E., 'Naturalized citizens: political participation, voting behavior, and impact on elections in Lebanon, 19962007', International Migration and Integration, 13 (2011), pp. 187-202

Houreld, K., 'South Sudanese exiles fear kidnap after activists disappear in Kenya', Reuters, 22 February 2017, <http://www.reuters.com/article/uksouthsudan-security-kenya-idUKKBN1611U0>, accessed 4 October 2017

Hovil, L., Refugees, Conflict, and the Search for Belonging (London: Palgrave Macmillan, 2016)

Huddleston, T. and Vink, M. P., 'Full membership or equal rights? The link between naturalisation and integration policies for immigrants in 29 European states', Comparative Migration Studies, 3/1 (2015) 
Human Rights Watch, 'Lebanon: deaths, alleged torture of Syrians in army custody', 20 July 2017, <https://www.hrw.org/news/2017/07/20/lebanondeaths-alleged-torture-syrians-army-custody>, accessed 26 June 2017

Hunger, U. and Candan, M., 'Politische Partizipation der Migranten in der Bundesrepublik Deutschland und über die deutschen Grenzen hinweg: Expertise im Auftrag des Bundesamts für Migration und Flüchtlinge' [Political participation of migrants in the Federal Republic of Germany and beyond German borders: expertise on behalf of the Federal Office for Migration and Refugees] (Münster: Universität Münster, FB Erziehungswissenschaft und Sozialwissenschaften, Institut für Politikwissenschaft, 2009), <http://www.ssoar.info/ssoar/handle/document/ 25950>, accessed 7 March 2018

Hurriyet Daily News, 'CHP, MHP oppose Turkish citizenship for Syrians', 7 July 2016a, <http://www.hurriyetdailynews.com/chp-mhp-oppose-turkishcitizenship-for-syrians.aspx?pageID $=238 \& \mathrm{nID}=101341 \& \mathrm{News} \mathrm{C}>$, accessed 20 July 2017

—, 'Syrians should be recognized as refugees: HDP co-chair Demirtas', 14 July 2016b,<http://www.hurriyetdailynews.com/syrians-should-be-recognized-asrefugees-hdp-co-chair-demirtas.aspx? pageID=238\&nid=101592\&NewsCatID=338>, accessed 20 July 2017

Hutcheson, D. S. and Arrighi, J. T., 'Keeping Pandora's (ballot) box half-shut: a comparative inquiry into the institutional limits of external voting in EU member states', Democratization, 22/5 (2015), pp. 884-905

Inkatha Freedom Party [South Africa], Constitution, 2012, <http:// www.ifp.org.za/wp-content/uploads/2015/03/Our-Constitution.pdf>, accessed 23 March 2018

International Crisis Group (ICG), Turkey's Refugee Crisis: The Politics of Permanence, Report No. 241, 30 November 2016, <https:// www.crisisgroup.org/europe-central-asia/western-europemediterranean/ turkey/turkey-s-refugee-crisis-politics-permanence>, accessed 20 July 2017

International Institute for Democracy and Electoral Assistance (International IDEA), The Global State of Democracy: Exploring Democracy's Resilience (Stockholm: International IDEA, 2017), <https://www.idea.int/gsod>, accessed 23 March 2018 
—, 'Refugees, Asylum Seekers and Democracy: Interview Questionnaire', [n.d.],<https://www.idea.int/publications/catalogue/political-participationrefugees-bridging-gaps>, accessed 7 April 2018

—, Voting from Abroad Database, <https://www.idea.int/data-tools/data/votingabroad>, accessed 23 March 2018

International Organization for Migration (IOM), 'Return of Qualified Afghans Programme Factsheet', September 2008, <http://www.iom.int/jahia/ webdav/shared/shared/mainsite/activities/countries/docs/afghanistan/ rqa_factsheet_sept08.pdf>, accessed 31 July 2017

—, Glossary on Migration, International Migration Law Series No. 25, 2011, <https://publications.iom.int/system/files/pdf/iml25_1.pdf>, accessed 19 February 2018

International Refugee Rights Initiative, 'The eligibility for refugees to acquire Ugandan citizenship', Citizenship Rights in Africa Initiative, 22 March 2016, <http://citizenshiprightsafrica.org/the-eligibility-for-refugees-toacquire-ugandan-citizenship/>, accessed 1 March 2018

Isaacson, L., 'Foreign workers may hold dual citizenship in South Africa', 6 November 2008, <https://www.skillsportal.co.za/content/foreign-workersmay-hold-dual-citizenship-south-africa>, accessed 18 June 2017

Kenya, Republic of, Constitution of Kenya, 2010, <https:// www.constituteproject.org/constitution/Kenya_2010?lang=en>, accessed 27 February 2018

Klotz, S., 'Selbstorganisation von Asylsuchenden: Teilhabeforderungen durch Zuwanderung' [Self-organization of asylum seekers: participation requirements due to immigration], Forschungsjournal Soziale Bewegungen, 29/2 (2016), pp. 60-69, <https://doi.org/10.1515/fjsb-2016-0208>, accessed 7 March 2018

Kuch, A., 'Naturalization of Burundian refugees in Tanzania: the debates on local integration and the meaning of citizenship revisited', Journal of Refugee Studies, 30/3 (2017), pp. 468-87

Lafleur, J. M., Transnational Politics and the State: The External Voting Rights of Diasporas (London and New York: Routledge, 2013) 
Long, K., Voting with their Feet: A Review of Refugee Participation and the Role of UNHCR in Country of Origin Elections and Other Political Processes, PDES/2010/12 (Geneva: UNHCR Policy Development and Evaluation Service, September 2010), <http://www.unhcr.org/research/evalreports/ 4ca08d249/voting-feet-review-refugee-participation-role-unhcr-countryorigin-elections.html>, accessed 5 March 2018

Lundgren, J. E., 'Repression across borders: homeland response to anti-regime mobilization among Syrians in Sweden', Diaspora Studies 8/2 (2015), pp. 104-19

Ministerium für Arbeit, Gesundheit und Soziales des Landes NordrheinWestfalen [Ministry for Labour, Health and Social Affairs of North RhineWestphalia, MAIS NRW], Migrantenselbstorganisationen Arbeit: Integration soziales [Migrant self-organization work: social integration], 2017, <https://www.mais.nrw/migrantenselbsthilfeorganisationen>, accessed 1 May 2017

Mannix, E., Political Participation of Refugees: The Case of Syrian Refugees in Turkey (Stockholm: International IDEA, 2018), <https:/www.idea.int/ publications/catalogue/political-participation-refugees-bridging-gaps>, accessed 7 April 2018

Mathenge, O., 'Kenya offers 24-hr security at local centres for Sudan vote', Daily Nation, 7 January 2011, <https://www.nation.co.ke/News/-/ 1056/1085370/-/11g0bxkz/-/index.html>, accessed 3 April 2018

McLoughlin, P., 'Beirut clamping down on Syrian refugee campaigns in Lebanon', Alaraby, 18 July 2017, <https:/www.alaraby.co.uk/english/ indepth/2017/7/18/lebanese-authorities-clamp-down-on-syrian-refugeecampaign>, accessed 26 July 2017

Mediendienst Integration [Integration Media Service], 'Abgeordnete mit Migrationshintergrund im 18. Deutschen Bundestag' [Members with a migration background in the 18th German Bundestag], 2013, $<$ https://mediendienst-integration.de/fileadmin/Dateien/ Abgeordnete_Bundestag_Ergebnisse.pdf>, accessed 8 January 2018

—, 'Abgeordnete mit Migrationshintergrund im 19. Deutschen Bundestag' [Members with a migration background in the 19th German Bundestag], October 2017, <https://mediendienst-integration.de/fileadmin/ MDI_Recherche_Bundestag_2017.pdf>, accessed 8 January 2018 
Migrationsverket [Swedish Migration Agency], 'Requirements for becoming a Swedish Citizen by application’, 24 April 2015,

<https:/www.migrationsverket.se/English/Private-individuals/Becoming-aSwedish-citizen/Citizenship-for-adults.html>, accessed 9 June 2017

—, 'Becoming a Swedish citizen: Time in Sweden', 23 January 2017, <https:// www.migrationsverket.se/English/Private-individuals/Becoming-a-Swedishcitizen/Citizenship-for-adults/Time-in-Sweden.html>, accessed 12 June 2017

Milner, J., 'Introduction: understanding global refugee policy', Journal of Refugee Studies, 27/4 (2014), pp. 477-94

Ministry of Social Affairs (Lebanon), Internal Governance for NGOs in Lebanon: Reference Book 2004, <http:/www.undp.org.lb/communication/ publications/downloads/IntGov_en.pdf>, accessed 3 April 2018

Mohamed, H. and Ibrahim, M., 'Somali Public Works Minister seen as "rising star" is shot to death', New York Times, 4 May 2017, <https:// www.nytimes.com/2017/05/04/world/africa/abbas-abdullahi-sheikh-sirajishot-somalia.html>, accessed 4 October 2017

L. Morales and M. Giugni (eds), Social Capital, Political Participation and Migration in Europe: Making Multicultural Democracy Work (Basingstoke: Palgrave Macmillan, 2016)

Morrice, L., 'British citizenship, gender and migration: the containment of cultural differences and the stratification of belonging', British Journal of Sociology of Education, 38/5 (2017), pp. 597-609,<http:// www.tandfonline.com/doi/pdf/10.1080/01425692.2015.1131606? needAccess=true $>$, accessed 31 July 2017

Mortimer, C., 'Laws restricting refugees' rights in Sweden spark backlash as thousands take to the streets', The Independent, 23 October 2016, <http:// www.independent.co.uk/news/world/europe/refugee-crisis-sweden-new-lawrestrict-asylum-claims-child-migrants-afghanistan-a7376656.html>, accessed 9 August 2017

Mpeiwa, M., Political Participation of Refugees: The Case of Congolese Refugees in South Africa (Stockholm: International IDEA, 2018), <https://www.idea.int/ publications/catalogue/political-participation-refugees-bridging-gaps>, accessed 7 April 2018 
Mundzic, L., Migrants and their Descendants: Social Inclusion and Participation in Society, Sweden, 2015, FRANET Country Report, 2015, <http:// fra.europa.eu/sites/default/files/fra_uploads/social-inclusion-and-migrantparticipation-society_se.pdf>, accessed 9 June 2017

Naharnet, 'Suleiman agrees to withdraw Lebanese nationalities from individuals "who don't deserve it", 29 October 2011, <http://www.naharnet.com/ stories/ar/18844>, accessed 24 July 2017

National Coalition of Syrian Revolution and Opposition Forces, 'Syrian coalition's mission in Turkey', [n.d.], <http://en.etilaf.org/coalition-units/ coalition-embassies/syrian-coalition-s-missionn-in-turkey.html>, accessed 20 July 2017

National Union of Journalists [UK], Asylum seeker members, 2017, <https:// www.nuj.org.uk/join/>, accessed 21 July 2017

Opon, C. O., Political Participation of Refugees: The Case of Somali and South Sudanese Refugees in Kenya (Stockholm: International IDEA, 2018), $<$ https:/www.idea.int/publications/catalogue/political-participationrefugees-bridging-gaps>, accessed 7 April 2018

Osman, M., 'Factbox: South Sudan referendum in Kenya', Sudan Tribune, 8 January 2011, <http://www.sudantribune.com/FACTBOX-South-SudanReferendum-in,37521>, accessed 20 June 2017

Pedroza, L., 'The democratic potential of enfranchising resident migrants', International Migration, 53/3 (2014), pp. 22-35

Porter, L., 'Syrians in Turkey celebrate Erdogan's triumph over coup attempt', Middle East Eye, 20 July 2016, <http://www.middleeasteye.net/news/syriansturkey-celebrate-erdogans-triumph-over-coup-attempt-365024068>, accessed 20 July 2017

Ragab, N., 'The engagement of the Syrian diaspora in Germany in peacebuilding', IS Academy Policy Brief No. 13, 2013, <https:// migration.unu.edu/publications/policy-briefs/the-engagement-of-the-syriandiaspora-in-germany-in-peacebuilding.html>, accessed 3 April 2018

-, Political Participation of Refugees: The Case of Afghan and Syrian Refugees in Germany (Stockholm: International IDEA, 2018), <https://www.idea.int/ publications/catalogue/political-participation-refugees-bridging-gaps $>$, accessed 7 April 2018 
Reuters, 'Tens of thousands of Syrian abroad vote in early poll', 28 May 2014, $<$ http://www.reuters.com/article/us-syria-crisis-electionidUSKBN0E815R20140528>, accessed 7 March 2018

Rhodes, S. and Harutyunyan, A., 'Extending citizenship to emigrants: democratic contestation and a new global norm', International Political Science Review, 31/4 (2010), pp. 470-93

RIA Novosti, 'Syrian opposition coalition to open office in Turkey', Sputnik News, 23 November 2012, <https://sputniknews.com/world/ 20121123177698440/>, accessed 20 July 2017

Ruedin, D., 'Participation in local elections: "Why don't immigrants vote more?", Parliamentary Affairs, Online First (2017), pp. 1-20, <https:// libra.unine.ch/Publications/36207/L-en>, accessed 6 April 2018

Ryan, B., 'Integration requirements: a new model in migration law', Journal of Immigration Asylum and Nationality Law, 22/4 (2008), pp. 303-16

Sachverständigenrat deutscher Stiftungen [Expert Council of German Foundations], 'Papiertiger oder Meilensteine? Die Integrationsgesetze der Bundesländer im Vergleich' [Paper tigers or milestones? A comparison of the integration laws of the federal states], 2017, <https://www.svr-migration.de/ wp-content/uploads/2017/09/SVR-FB_Integrationsgesetze.pdf>, accessed 7 March 2018

Schönwälder, K., Sinanoglu, C. and Volkert, D., Vielfalt sucht Rat: Ratsmitglieder mit Migrationshintergrund in deutschen Großstädten [Diversity seeks advice: council members with a migration background in major German cities] (Berlin: Heinrich-Böll-Stiftung, 2011)

Schröder, C., 'Flüchtlingsproteste in Deutschland' [Refugee protests in Germany], Forschungsjournal Soziale Bewegungen, 27/2 (2016), pp. 100-04, <https://doi.org/10.1515/fjsb-2014-0211>, accessed 7 March 2018

Shams, S. and Khan, F., 'Afghan refugees barred from voting in presidential elections', Deutsche Welle, 3 April 2014, <http://www.dw.com/en/afghanrefugees-barred-from-voting-in-presidential-elections/a-17541772>, accessed 21 July 2017

Sharifi, S., Political Participation of Refugees: The Case of Afghan Refugees in the United Kingdom (Stockholm: International IDEA, 2018), <https:// 
www.idea.int/publications/catalogue/political-participation-refugeesbridging-gaps>, accessed 7 April 2018

Slavu, C., 'Afghanistan's 2004 presidential election: External voting for a large displaced population', in A. Ellis et al. (eds), Voting from Abroad: The International IDEA Handbook (Stockholm and Mexico City: International IDEA and Federal Electoral Institute of Mexico, 2007), pp. 158-62, $<$ https://www.idea.int/publications/catalogue/voting-abroad-internationalidea-handbook>, accessed 5 April 2018

—, 'External voting for Afghanistan's 2004 presidential election', in Afghanistan Analysts Network, 'Snapshots of an Intervention', 7 July 2012, <https:// www.afghanistan-analysts.org/publication/aan-e-books/aans-first-e-booksnapshots-of-an-intervention/>, accessed 6 April 2018

Smith, H. and Stares, P., Diasporas in Conflict: Peace-Makers or Peace-Wreckers? (Tokyo: United Nations University Press, 2007)

Sozialdemokratische Partei Deutschlands [Social Democratic Party of Germany, SPD], 'Mitglied werden' [Become a member], 2017, <https://www.spd.de/ unterstuetzen/mitglied-werden/>, accessed 23 April 2017

Somaliska Riksförbundet i Sverige [Somali Association in Sweden], Homepage, <http://www.srfs.se/index.php/en/>, accessed 9 June 2017

South Africa, Republic of, Constitution of the Republic of South Africa, 1996, <http://www.elections.org.za/content/Documents/Laws-and-regulations/ Constitution/Constitution-of-the-Republic-of-South-Africa,-1996/>, accessed 6 June 2017

Staniewicz, T., Migrants and their Descendants: Social Inclusion and Participation in Society, United Kingdom, 2015, FRANET Country Report, 2015, <http:// fra.europa.eu/sites/default/files/fra_uploads/social-inclusion-and-migrantparticipation-society_uk.pdf>, accessed 30 July 2017

Statistics South Africa, 'Statistics on the non-profit sector for South Africa, 2010 to 2014', 2017, <http://www.statssa.gov.za/?

page_id=1854\&PPN=D0407.2>, accessed 14 March 2018

Statistiska Centralbyrån [Statistics Sweden], 'General elections, participation survey 2014', 2014, <http://www.scb.se/en/finding-statistics/statistics-bysubject-area/democracy/general-elections/general-elections-participationsurvey/>, accessed 12 December 2017 
—, 'General elections, participation survey: Increased turnout among the young and old', 30 March 2015, <https://www.scb.se/en_/finding-statistics/ Statistics-by-subject-area/Democracy/General-elections/General-electionsparticipation-survey/Aktuell-Pong/12311/Behallare-for-Press/387425/>, accessed 12 December 2017

Swedish Agency for Youth and Civil Society, Homepage, <https://eng.mucf.se/>, accessed 7 August 2017

Syrian Center for Political and Strategic Studies, 'Mission', [n.d.], <http:// scpss.org/en/?page_id=11>, accessed 23 August 2017

Syrian Social Nationalist Party (SSNP), Official website, 2017, <http:// www.ssnp.com/new/about.htm>, accessed 25 July 2017

Thielemann, E. and Hobolth, M., 'Trading numbers vs. rights? Accounting for liberal and restrictive dynamics in the evolution of asylum and refugee policies', Journal of Ethnic and Migration Studies, 42/4 (2016), pp. 643-64

Turkish Interior Ministry Bureau of Associations, 'Dernek Kuruluşu için Gerekli Belgeler' [Documents required to form an association], <https:// www.dernekler.gov.tr/tr/anasayfalinkler/ dernek_kurulusu_icin_gerekli_belgeler.aspx>, accessed 20 July 2017

United Nations, 'Global Compact for Safe, Orderly and Regular Migration', Zero Draft, 5 February 2018, <https://refugeesmigrants.un.org/ intergovernmental-negotiations $>$, accessed 6 April 2018

United Nations Economic and Social Council, Commission on Human Rights, 'Guiding Principles on Internal Displacement', 11 February 1998, <http:// daccess-ods.un.org/access.nsf/Get?Open\&DS=E/CN.4/1998/53/Add. 2\&Lang=E $>$, accessed 6 April 2018

United Nations General Assembly Resolution 71/1 [New York Declaration for Refugees and Migrants], 19 September 2016

United Nations High Commissioner for Refugees (UNHCR), Convention and Protocol relating to the Status of Refugees, 1951, <http://www.unhcr.org/ 3b66c2aa10>, accessed 6 Feb 2018

-, OAU Convention governing the specific aspects of refugee problems in Africa, 1969, <http://www.unhcr.org/about-us/background/45dc1a682/ oau>, accessed 10 February 2018 
—, Cartagena Declaration on Refugees, 1984, <http://www.unhcr.org/about-us/ background/45dc19084/cartagena-declaration-refugees-adoptedcolloquium-international-protection.html>, accessed 10 February 2018

-, Executive Committee, 56th session, 'Conclusion on Local Integration No. 104 (LVI)', 7 October 2005, <http://www.unhcr.org/excom/exconc/ 4357a91b2/conclusion-local-integration.html>, accessed 4 April 2018

—, 'Global Trends: Forced Displacement in 2015', 2016, <http:// www.unhcr.org/statistics/unhcrstats/576408cd7/unhcr-globaltrends-2015.html>, accessed 10 February 2018

—, 'Global Trends: Forced Displacement in 2016', 2017a, <http:// www.unhcr.org/5943e8a34.pdf>, accessed 10 February 2018

—, 'Syria Regional Refugee Response: Turkey', updated 6 July 2017b, <http:// data.unhcr.org/syrianrefugees/country.php?id=224>, accessed 19 July 2017

—, 'The global compact on refugees', Zero Draft, 31 January 2018, <http:// www.unhcr.org/Zero-Draft.pdf>, accessed 3 March 2018

UN Human Rights Council, 'Report of the Special Rapporteur on the rights to freedom of peaceful assembly and of association, Maina Kiai', A/HRC/ 26/29, 14 April 2014, <http://www.ohchr.org/Documents/Issues/ FAssociation/A-HRC-26-29_en.pdf>, accessed 1 March 2018

-, 'Report of the independent expert on minority issues, Gay McDougall', A/ HRC/13/23, 7 January 2010, <http://www2.ohchr.org/english/bodies/ hrcouncil/docs/13session/A-HRC-13-23.pdf>, accessed 2 March 2018

Valmyndigheten [Swedish Election Authority], Val till kommunfullmäktige Röster [Elections to the city council: voting], 18 February 2014, <http:// www.val.se/val/val2014/slutresultat/K/rike/index.html>, accessed 21 December 2017

Vicente, M., 'Die Arbeit der Integrationsbeiräte in Deutschland' [The work of the Integration Advisory Councils in Germany], Forschungsjournal Soziale Bewegungen, 24/2 (2011), pp. 38-43

Vink, M. P., De Groot, G. R. and Luk, N. C., MACIMIDE Global Expatriate Dual Citizenship Dataset, Version 2, 2015, <https://doi.org/10.7910/DVN/ TTMZ08>, accessed 6 April 2018 
Weiss, K., 'Migrantenorganisationen und Staat. Anerkennung, Zusammenarbeit, Förderung' [Migrant organizations and state: recognition, cooperation, promotion], in G. Schultze and D. Thränhardt (eds), Migrantenorganisationen: Engagement, Transnationalität und Integration [Migrant organizations: commitment, transnationality and integration] (Bonn: Friedrich-Ebert-Stiftung, 2013)

Wight, J., 'Hezbollah's role in Syria and Israel's dilemma', RT, 2 April 2017, <https://www.rt.com/op-edge/383124-syria-hezbollah-israel-war>, accessed 21 June 2017

Wimmer, A., Waves of War: Nationalism, State Formation, and Ethnic Exclusion in the Modern World (Cambridge: Cambridge University Press, 2012)

Zakaryan, T., Political Participation of Refugees: The Case of Congolese and South Sudanese Refugees in Uganda (Stockholm: International IDEA, 2018), $<$ https://www.idea.int/publications/catalogue/political-participationrefugees-bridging-gaps>, accessed 7 April 2018

Zetter, R., 'More labels, fewer refugees: Remaking the refugee label in an era of globalization', Journal of Refugee Studies, 20/2 (2007), pp. 172-92

Ziegler, R., Voting Rights of Refugees (Cambridge: Cambridge University Press, 2017)

Zogby, J., “'You stink"', Huffington Post, 28 August 2015, <https:// www.huffingtonpost.com/james-zogby/you-stink_b_8056484.html>, accessed 20 November 2017

Zolberg, A., Suhrke, A. and Aguayo, S., Escape from Violence: Conflict and the Refugee Crisis in the Developing World (Oxford: Oxford University Press, 1989) 


\section{Legislation}

\section{Afghanistan}

Election Law [English translation], 25 September 2016, <http://moj.gov.af/ content/files/OfficialGazette/01201/OG_01226_English.pdf>, accessed 16 March 2018

\section{Germany}

Staatsangehörigkeitsgesetz [Nationality Act], 22 July 1913 (last amended 11 October 2016), <https://www.gesetze-im-internet.de/rustag/ BJNR005830913.html>, accessed 7 March 2018

Zweites Gesetz zur Änderung des Staatsangehörigkeitsgesetzes [Second Act amending the Nationality Act], 13 November 2014, Bundesanzeiger Verlag [German Federal Gazette], <http://www.bgbl.de/xaver/bgbl/start.xav? startbk=Bundesanzeiger_BGBl\&jump To=bgbl114s1714.pdf $>$, accessed 6 April 2018

\section{Kenya}

Kenya Citizenship and Immigration Act, 2011, <http://www.kenyalaw.org/lex// actview.xql? actid=No.\%2012\%20of\%202011 >, accessed 27 February 2018

\section{South Africa}

Citizenship Act, 1995 (as amended in 2010), <https://www.gov.za/sites/ www.gov.za/files/a17_2010_0.pdf>, accessed 6 June 2017

Electoral Act, 1998 (as amended in 2013), <http://www.elections.org.za/content/ Documents/Laws-and-regulations/Elections/Electoral-Act-73-of-1998including-Regulations/>, accessed 7 June 2017

Electoral Commission Act, 1996, <http://www.elections.org.za/content/ Documents/Laws-and-regulations/Electoral-Commission/ElectoralCommission-Act-51-of-1996-including-Regulations/>, accessed 7 June 2017

Nonprofit Organizations Act, 1997, <https:/www.gov.za/documents/nonprofitorganisations-act>, accessed 3 April 2018

Regulation of Gatherings Act, 1993, <https:/www.gov.za/sites/default/files/ Act205of1993.pdf>, accessed 7 June 2017 


\section{Sweden}

Local Government Act, 2004, <http://www.government.se/49b736/ contentassets/9577b5121 e2f4984ac65ef97ee79f012/the-swedish-localgovernment-act>, accessed 22 March 2018

\section{Syria}

Law No. 5 on General Elections, 2014, <http://www.ilo.org/dyn/natlex/docs/ ELECTRONIC/98926/117885/F519410355/98926.pdf>, accessed 26 March 2018

\section{Turkey}

Türk Vatandaşlı̆̆ı Kanunu [Turkish Citizenship Act], 2009, <http:// www.refworld.org/pdfid/4a9d204d2.pdf>, accessed 3 April 2018

\section{Uganda}

Uganda Citizenship and Immigration Control Act, 1991, <http:// www.refworld.org/cgi-bin/texis/vtx/rwmain/opendocpdf.pdf? reldoc $=\mathrm{y} \&$ docid $=544 \mathrm{e} 4 \mathrm{e} 554>$, accessed 4 July 2017

Refugees Act, 2006, <http://www.refworld.org/docid/4b7baba52.html>, accessed 22 May 2017 


\section{Annex. Glossary of terms}

\section{Asylum}

A form of protection given by a state on its territory based on internationally or nationally recognized refugee rights. It is granted to a person who is unable to seek protection in her or his country of nationality and/or residence, in particular for fear of being persecuted for reasons of race, religion, nationality, membership of a particular social group or political opinion.

\section{Asylum seeker}

A person who seeks safety from persecution or serious harm in a country other than her or his own and is awaiting a decision on an application for refugee status under relevant international and national instruments.

\section{Country of origin}

A country from which people leave to settle abroad permanently or temporarily (IOM 2011).

\section{Diaspora}

A group of individuals (and members of networks, associations and communities) who have left their country of origin but maintain links with their homeland. This concept covers more settled communities, migrant workers based abroad temporarily, expatriates with the nationality of the host country, dual nationals, and second- and third-generation migrants. 


\section{Formal political participation}

For the purposes of this research, formal political participation is understood as participation in decision-making through formal democratic institutions and processes such as national and local elections, referendums, political parties and parliaments.

\section{Host country}

The country where a refugee is settled. In the case of asylum seekers, the country where a person has applied for asylum.

\section{Internally displaced person}

A person who has been forced or obliged to flee or to leave their home or places of habitual residence, in particular because of (or in order to avoid) the effects of armed conflict, situations of generalized violence, violations of human rights, or natural or human-induced disasters, but who has not crossed an internationally recognized state border (United Nations Economic and Social Council, Commission on Human Rights 1998).

\section{Migrant}

Any person who is moving or has moved across an international border or within a state away from her/his habitual place of residence, regardless of (a) the person's legal status; (b) whether the movement is voluntary or involuntary; (c) what the causes for the movement are; or (d) what the length of the stay is (IOM 2011).

\section{Naturalization}

Granting by a state of its nationality to a non-national through a formal act on the application of the individual concerned (IOM 2011).

\section{Non-formal political participation}

For the purposes of this research, non-formal political participation is understood as participation in political affairs through non-formal means, such as civil society organizations, trade unions, consultative bodies, community organizations, grassroots movements and so on.

\section{Refugee}

'A person who, owing to a well-founded fear of persecution for reasons of race, religion, nationality, membership of a particular social group or political opinions, is outside the country of his nationality and is unable or, owing to such fear, is unwilling to avail himself of the protection of that country' (Refugee Convention, article 1A(2), 1951). In addition, article 1(2) of the 1969 Organization of African Unity Convention defines a refugee as any person 
compelled to leave her or his country 'owing to external aggression, occupation, foreign domination or events seriously disturbing public order in either part or the whole of his country of origin or nationality'. Similarly, the 1984 Cartagena Declaration states that refugees also include persons who flee their country 'because their lives, security or freedom have been threatened by generalized violence, foreign aggression, internal conflicts, massive violations of human rights or other circumstances which have seriously disturbed public order' (IOM 2011).

\section{Resettlement}

The transfer of refugees from the country in which they have sought refuge to another state that has agreed to admit them (IOM 2011).

\section{Transnationalism}

The process whereby people establish and maintain socio-cultural connections across geopolitical borders (IOM 2011). 


\section{About the authors}

\section{Lead authors}

Armend Bekaj is a Senior Programme Officer at International IDEA. In addition to working on projects related to diversity and political inclusion of marginalized groups, he is part of the team in charge of producing the Institute's biennial publication, The Global State of Democracy. He has more than 15 years' experience working for international organizations such as the OSCE and USAID, as well as numerous civil society organizations, focusing on areas of good governance, democratization and electoral assistance. Most of his field experience comes from the Western Balkans. He has also worked for the British Refugee Council, helping asylum seekers and refugees get settled into the country and mediating with the Home Office on their behalf. $\mathrm{He}$ is a $\mathrm{PhD}$ candidate with the University of Sheffield and his area of academic expertise is political transformation and the inclusion of former combatants in politics. He has been part of numerous related research initiatives and published articles on the topic. He has also taught various international relations-related subjects at the Rochester Institute of Technology-Kosovo.

Lina Antara is a democracy support professional with a keen interest in electoral processes and human rights. She has worked as a Programme Officer at International IDEA since 2015, focusing on projects related to the political inclusion of marginalized groups. Previously, she worked with International IDEA's electoral support project in Myanmar, and with the Electoral Processes Programme conducting research for the Electoral Justice Database and the ACE Electoral Knowledge Network. Prior to this, she worked for the Court of Justice of the European Union and the European Parliament in Luxembourg. She also 
served as an election observer with the Organization of American States in Panama in 2014 and with the European Union in Liberia in 2017. She holds a master's degree in European law from the University of Luxembourg, a postgraduate degree in international election observation and electoral assistance from the University of the Basque Country, and a bachelor's degree in law from the Aristotle University of Thessaloniki.

\section{Contributors}

Tarig Adan is a Somali refugee living in Sweden. She specializes in local integration, the promotion of human rights, the protection of vulnerable persons and the prevention of sexual and gender-based violence. She holds a degree in social work and community development from Kampala International University. She has previously worked with various humanitarian and development organizations in East Africa and the Horn of Africa on issues related to refugees, internally displaced persons and mix-migration groups. Her main interest is in working with and assisting vulnerable groups, in particular women and children, who have been through war and gender-based violence.

Jean-Thomas Arrighi de Casanova is a research fellow affiliated with the Swiss Forum of Migration and Population Studies of the University of Neuchâtel, as well as a lecturer in politics at the universities of Neuchâtel and Lucerne and an associate researcher at the GRITIM Research Group on Immigration, Pompeu Fabra University. He was awarded a PhD by the Department of Social and Political Sciences of the European University Institute (EUI) in 2012 and has held postdoctoral positions at the GLOBALCIT Observatory of the EUI (201215) and the University of Michigan in Ann Arbor (2014). His research interests include migration, nationalism, comparative politics, territorial politics and normative theory.

Zeina El-Helou was elected to serve as the Secretary General of the Lebanese Association for Democratic Elections for the two-year term March 2016-March 2018. She has been an activist in the field of human rights, good governance and democracy since 1998 and has more than 16 years of experience in policy research and development. She worked at the Lebanese Center for Policy Studies (LCPS) in 2006-10 and is currently associated with LCPS as a Senior Researcher. She has conducted a number of field research studies on socio-political issues since 2008. She holds a master's degree in journalism from Université Assas-Paris II in collaboration with the Lebanese University, and a master's degree in political science from Saint-Joseph University. 
Ezra Mannix is a writer, web editor and teacher who lived in Istanbul in the period 2009-16. He returned to his native United States in 2016 to study for a masters in law and diplomacy from the Fletcher School at Tufts University. After working in magazine journalism and NGO communications in Florida and New York, he taught English to university students in Istanbul and maintained a website, ezramannix.com. His interests include development and the economic and political integration of refugees.

Mukondeleli Mpeiwa is a professional diplomat with over 10 years' experience in fields such as international finance and development, disaster management, international migration management, and peace and security. She has a keen interest in human rights and humanitarian support work, especially in the African context. She completed her undergraduate studies in international relations at the University of Pretoria, and postgraduate studies in international relations and diplomacy at the University of South Africa. She has worked in the South African public service, at the United Nations and for other international organizations, and has served as a training expert, content developer and multidisciplinary analyst, as well as a capacity-building trainer at the community and grassroots levels.

Caleb Otieno Opon has a diverse background in research, policy and strategy on issues related to African development. His area of focus is understanding the processes and mechanisms by which traditionally underrepresented groups can achieve both economic and political inclusion, representation and influence. He has worked with private sector finance institutions, development partners, international NGOs and the Kenyan Government on issues around the economic and political empowerment of marginalized groups, especially after the political crisis of 2007 which created a large number of internally displaced persons and refugees. He worked for the African Research and Resource Forum on establishing a lasting peace in South Sudan through initiatives to encourage democratic dialogue among the South Sudanese diaspora, including refugees and asylum seekers, with support from the African Capacity Building Foundation $(\mathrm{ACBF})$. He has also worked with International IDEA and the Independent Electoral and Boundaries Commission of Kenya on electoral issues. Since 2017, he has been working as a Senior Economic and Political Adviser to the Governor of the County Government of Kisumu in the Strategy, Policy and Delivery Unit.

Nora Jasmin Ragab is a $\mathrm{PhD}$ student and researcher in the Migration and Development research cluster at Maastricht University, Maastricht Graduate School of Governance. Her main research interest lies in the area of migration and development, with a focus on diaspora mobilization in conflict settings. The aim of her $\mathrm{PhD}$ project is to provide a broader understanding of the role and 
contribution of diasporas in conflicts and peacebuilding in their country of origin using the Syrian diaspora as a case study. She finished her bachelor's degree in business, economics and social sciences at Vienna University of Economics and Business and completed her master's degree in public policy and human development with a specialization in migration studies at Maastricht University. In addition to this research project she also collaborates closely with migrant organizations in her role as intercultural consultant, which gives her access to different migrant communities in Germany.

Shoaib Sharifi is an award-winning Afghan journalist and filmmaker with extensive experience in the field of reporting news and current affairs and making documentaries. He has more than 15 years' experience in journalism with wellknown news agencies and television networks, most notably as Editor-in-Chief of The Kabul Times, UN humanitarian reporter for Afghanistan IRIN News, radio producer/presenter for the BBC World Service in London and freelance producer/director for the BBC, Channel 4 and ITV television channels in the $\mathrm{UK}$, as well as PBS America [Frontline], MSNBC and ABC Australia. His interests and expertise lie in reporting the plight of refugees and asylum seekers. In the past five years he has travelled extensively to host countries and countries of origin along the route South Asian migrants take when travelling to Turkey and Europe to make reports and documentaries for the $\mathrm{BBC}$ and Channel 4 television.

Tigranna Zakaryan is a researcher based in Kampala, Uganda. She authored the Uganda case study in collaboration with the International Refugee Rights Initiative, a research and advocacy organization that works to address causes of conflict-related displacement in Africa and to ensure that the rights of those forced to leave their homes are respected by local, regional and international stakeholders both in policy and in practice. Her research objectives focus on refugee management, genocide and mass atrocity prevention, community-driven solutions to displacement, and effective state-building mechanisms. She works closely with refugee-led civil society organizations and diaspora networks to bridge the gaps between the daily realities of refugees, and broader forced migration policies and global debates. 


\section{About the Refugees, Asylum Seekers and Democracy project}

Refugees have the potential to make an impact on the political life of both their host countries and their countries of origin, as they often maintain transnational links with their homelands while at the same time becoming part of their host society. Recognizing the dual role of refugees as political actors, the Refugees, Asylum Seekers and Democracy project aims to explore the challenges and opportunities related to the political participation of refugees in their host countries and countries of origin.

Among the formal mechanisms for political participation, the project explores issues of access to citizenship in host countries, electoral rights in both host countries and countries of origin, and membership or other forms of support to political parties. In addition, acknowledging that political life is not only confined to electoral processes, the project examines non-formal mechanisms for political participation, including refugees' participation in consultative bodies, civil society organizations, protests and grassroots initiatives, and other means of transnational political activism.

The Refugees, Asylum Seekers and Democracy project was made possible by funding from the Robert Bosch Stiftung.

$<$ https://www.idea.int/our-work/what-we-do/migration-democracy> 


\section{About International IDEA}

The International Institute for Democracy and Electoral Assistance (International IDEA) is an intergovernmental organization with the mission to advance democracy worldwide, as a universal human aspiration and enabler of sustainable development. We do this by supporting the building, strengthening and safeguarding of democratic political institutions and processes at all levels. Our vision is a world in which democratic processes, actors and institutions are inclusive and accountable and deliver sustainable development to all.

\section{What do we do?}

In our work we focus on three main impact areas: electoral processes; constitution-building processes; and political participation and representation. The themes of gender and inclusion, conflict sensitivity and sustainable development are mainstreamed across all our areas of work. We provide analyses of global and regional democratic trends; produce comparative knowledge on good international democratic practices; offer technical assistance and capacitybuilding on democratic reform to actors engaged in democratic processes; and convene dialogues on issues relevant to the public debate on democracy and democracy building.

\section{Where do we work?}

Our headquarters is located in Stockholm, and we have regional and country offices in Africa, the Asia-Pacific, Europe, and Latin America and the Caribbean. International IDEA is a Permanent Observer to the United Nations and is accredited to European Union institutions.

$<$ http://www.idea.int> 
What can be done to enhance the participation of refugees and asylum seekers in the political life of their host countries and their countries of origin? What legal and institutional mechanisms are needed to create enabling environments to foster their participation, and which factors might hinder this participation?

This report explores the possible answers to these questions, focusing on refugees from Afghanistan, the Democratic Republic of the Congo, Somalia, South Sudan and Syria, and their experiences in eight host countries: Germany, Kenya, Lebanon, South Africa, Sweden, Turkey, Uganda and the United Kingdom.

Drawing on a total of 638 in-depth interviews with refugees and key informants, the report provides unique insights into the challenges and opportunities related to refugees' political participation. 